\title{
The Role of Private Vending in Developing Country Water Service Delivery: The Case of Karachi, Pakistan.
}

\author{
by
}

\author{
Roohi Abdullah
}

\author{
B.Arch., Architecture (1993) \\ Dawood College of Engineering and Technology \\ NED University, Karachi, Pakistan.
}

Submitted to the Department of Urban Studies and Planning
in Partial Fulfillment of the Requirements for the Degree of

Master in City Planning

at the

ROTCH

Massachusetts Institute of Technology

MASSACHUSETTS INSTITUTE

OF TECHNOLOGY

June 1999

(C) 1999 Roohi Abdullah

JUL 191999

All rights reserved

The author hereby grants to MIT permission to reproduce and to distribute publicly paper and electronic copies of this thesis document in whole or in part.

Signature of Author..

Roohi Abdullah

Department of Urban Studies and Planning

May 20, 1999

Certified by

Jennifer Davis

Assistant Professor, Department of Urban Studies and Planning

Thesis Supervisor

Accepted by

Associate Professor Paul Smoke

Chairman, Master in City Planning Committee

Department of Urban Studies and Planning 


\title{
The Role of Private Vending in Developing Country Water Service Delivery: The Case of Karachi, Pakistan.
}

\author{
By \\ Roohi Abdullah \\ Submitted to the Department of Urban Studies and Planning \\ on May 20, 1999 in partial fulfillment of the requirements \\ for the Degree of Master in City Planning
}

\begin{abstract}
The private water vending industry in Karachi is an important source of water service delivery in Karachi, Pakistan. Water vending is largely a supplemental service to households with private water connections, due to limited service from the public utility. This research attempts to:

i) Characterize the existing water supply situation in Karachi, with particular focus on the water vending industry;

ii) Evaluate the extent to which water vending in Karachi affects households' water supply situation and generates excessive profits for vendors; and

iii) Assess possible strategies for water sector reform in Karachi.
\end{abstract}

The case of Karachi, where water vending coexists with a piped supply network, poses a challenge to policy makers in water supply planning. The study shows that the major clients of vended water in the city are those who have water connections, storage capacity, and the ability to buy water.

The key findings of the study are:

i) Karachi's water vending market may not be economically efficient. Although the vending market provides only $9 \%$ of the water consumed by city residents on a daily basis, it earns almost $50 \%$ of all revenues received from water.

ii) Groundwater supplying households' wells and private hydrants is not recognized as a common property resource by the concerned public agencies. As a result, existing government policy fails to address the consequences of unregulated groundwater use by private individuals.

iii) Surprisingly, a market for vended water exists even in a city where more than $3 / 4$ of all households are served by piped water connections. When levels of the public utility's service are low - in this case an average of 3 hours of service each day - households are forced to turn to other sources to meet their water supply needs.

In view of these findings, there appears to be a need for regulatory reforms. The study proposes the adoption of a dual strategy to solve the problem of rent seeking by hydrant owners in Karachi: regulation, and promotion of competition.

Thesis Supervisor: Jennifer Davis

Title: Assistant Professor, Urban Studies and Planning 


\section{An unfavourable task; lest I forget a favor, An unavoidable inscription, for all consideration An indebtness, to all I owe.}

Alhamdolilah - I thank Almighty Allah who gave me the energy and ability to complete this thesis, however its still remains a work in progress.

For helping me crystallize my ideas, I thank my advisor Jennifer Davis, for all I have learnt from her during the rigorous writing process of the thesis. Thank you Jennifer, for knowing when to pull the right strings: for giving me strict and highly demanding comments when I was struggling with my ideas, and for disciplining me to get start started, when I needed it most. For being so patient and also assertive when their was a need for it and finally giving me all the support, encouragement and time, when the writing process simply seemed too much for me to handle. This work would not have realized in its present form if it were not for Jennifer's comments and quality feedback, always pushing me for more. I am also grateful to my reader Meenu Tewari, for her provocative questions that always forced me to think beyond what was apparent, pushing me to 'go a little more', for her substantive discussions and insightful, "high-precision" comments.

I extend my gratitude to many individuals and organizations who in their own way provided assistance, both during my field work and during the writing process; without which it would not have been possible to complete this research. I especially would like to thank the vendors and households in Karachi who cooperated in sharing information about their water service delivery situation without any reservations making it an interesting inquiry.

My friends who helped me pulled my thesis together, laboriously editing and proof editing, I would like to say a special thank you to all: Reema, Maysa, Nadine, Farzana, Neal, Katrina, Geri, Jinevra, Julie and Nicholas.

Financial support through Joosub H. S. Ebrahim Foundation for my first year at MIT, and the American Association of University Women Fellowship (AAUW) for the second year made it possible for me to attend MIT.

For making my two years at MIT a memorable experience, I thank my friends, for all they have shared and for all I have learnt from them not just academically but also personally; Maysa, Poonam, Shailesh, Ayman, Steve, Nicholas, Katrina, Geri, Marinella, Nicholas, Atif, and Samad.

My acknowledgments cannot be complete without thanking everyone in PSS group and CRL for making my two years a fun technological ride at MIT. My corner in CRL backyard, the computers, Phil, Tom, Sue, Anne, Mike, Ching, Dsk, and Joe always showing concern and support in whatever way possible - this is a special thank you for all of you.

For everything they have done for me throughout their lives, for making it possible for me to come to MIT, I thank my parents. Daddy and Mummy for their continuing encouragement, affection and steadiness that provided me with the personal strength; not only to complete this thesis, but for everything in my life. I would also like to extend my appreciation to my brother, for looking after 'his little sister', for his consistent support through internet chats, e-mails and phone calls, always making sure he was there for me. All this would not have been possibly without the consistent support and encouragement of my dear parents and brother. They have done more in these two years I been here at MIT- worrying about me from a distant and always offering support in whatever way possible.

..This thesis is dedicated to my family (mummy, daddy and arif bhai) for being the most fun and reliable team and for always being there. 
A B S T R A C T

ACK N OWLEDGEMENTS

LIST OF TABLE, FIGURES AND MAPS

$\begin{array}{llllllllll}\mathbf{C} & \mathbf{H} & \mathbf{A} & \mathbf{P} & \mathbf{T} & \mathbf{E} & \mathbf{R} & \mathbf{O} & \mathbf{N} & \mathbf{E}\end{array}$

I N T R O D U C T I O N

$\begin{array}{llllllllll}\mathbf{C} & \mathbf{H} & \mathbf{A} & \mathbf{P} & \mathbf{T} & \mathbf{E} & \mathbf{R} & \mathrm{T} & \mathbf{W} & \mathbf{O}\end{array}$

OVERVIEW OF KARACH I AND STUDY APPROACH

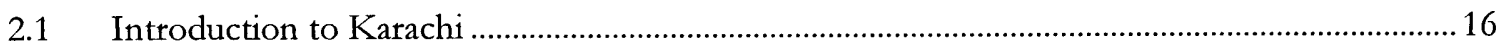

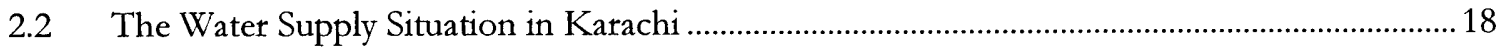

2.2.1 Key Stakeholder in Water Service Delivery ............................................................................... 19

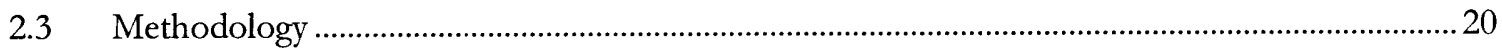

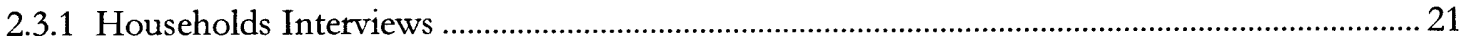

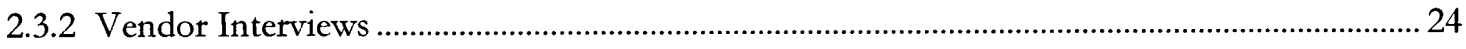

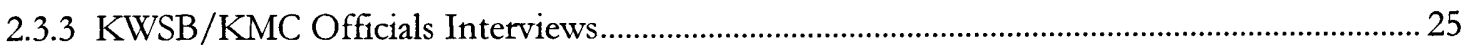

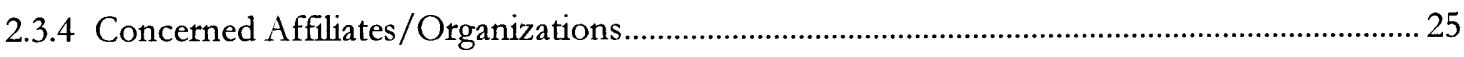

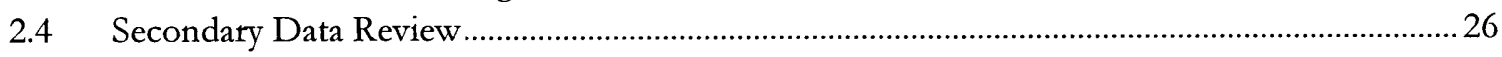

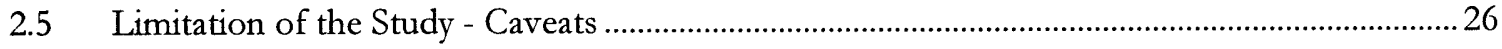

2.6 Socioeconomic Characteristics of the Sample Respondents .........................................................2

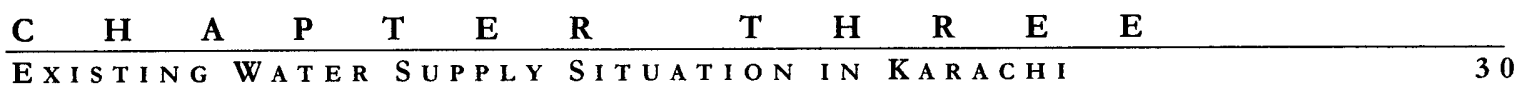

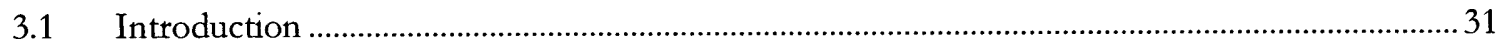

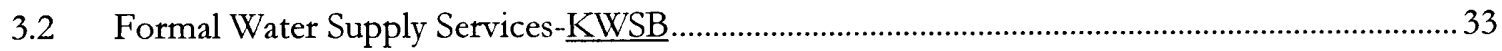

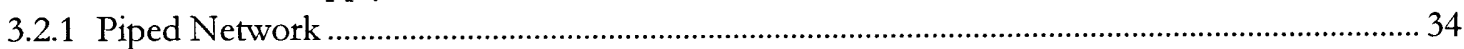

3.2.2 KWSB's Hydrant Supply through Tanker Trucks .................................................................. 41

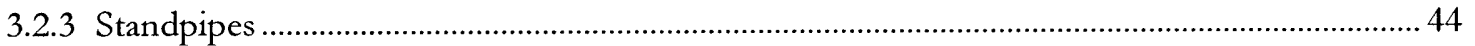

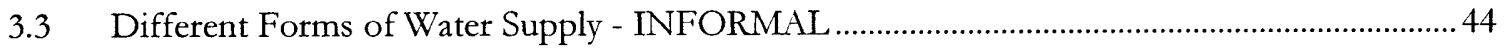

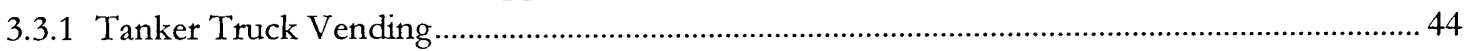

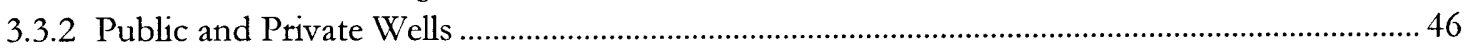

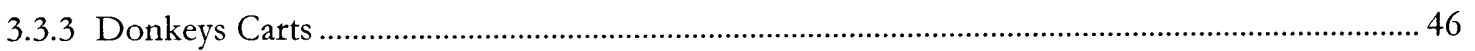

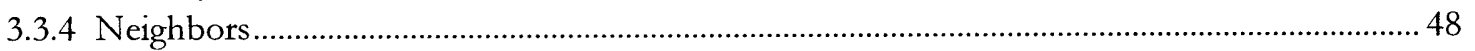

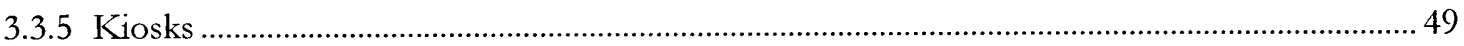

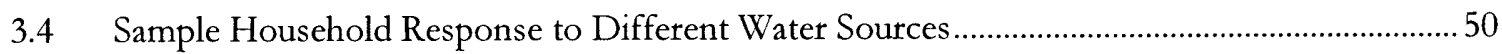

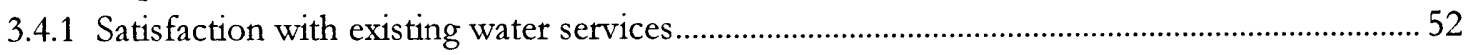

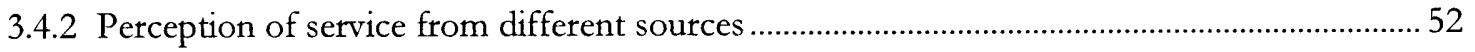

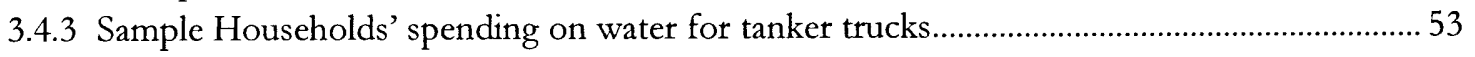

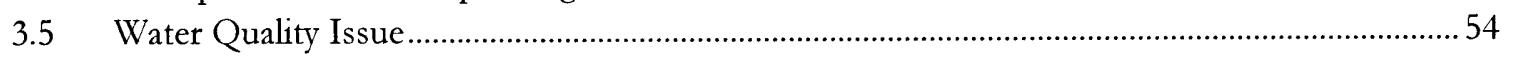




\begin{tabular}{llllllllllllllll}
$\mathrm{T}$ & $\mathrm{A}$ & $\mathrm{B}$ & $\mathrm{L}$ & $\mathrm{E}$ & $\mathrm{O}$ & $\mathrm{F}$ & $\mathrm{C}$ & $\mathrm{O}$ & $\mathrm{N}$ & $\mathrm{T}$ & $\mathrm{E}$ & $\mathrm{N}$ & $\mathrm{T}$ & $\mathrm{S}$ & \\
\hline
\end{tabular}

$\begin{array}{lllllllllll}\mathbf{C} & \mathbf{H} & \mathbf{A} & \mathbf{P} & \mathbf{T} & \mathbf{E} & \mathbf{R} & \mathbf{F} & \mathbf{O} & \mathbf{U} & \mathbf{R}\end{array}$

W A T ER VENDING IN KARACHI

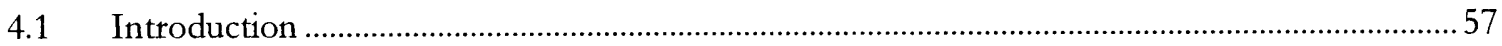

4.2 Primary Distributors: Tanker Truck Vendors and Owners ........................................................ 59

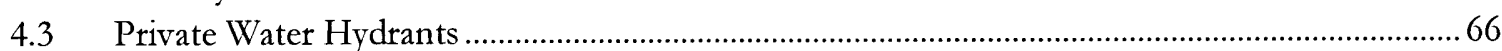

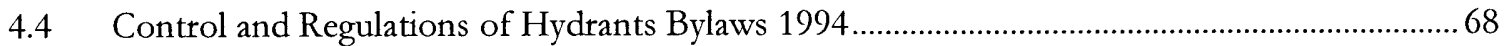

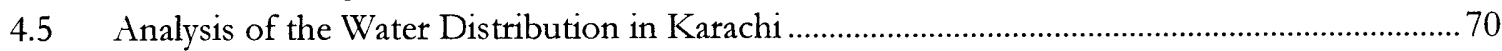

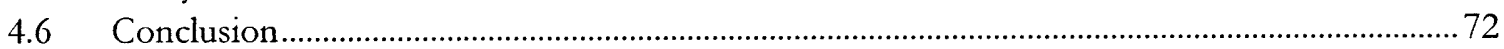

\begin{tabular}{llllllllllll} 
C & H & A & P & T & E & R & F & I & V & E & \\
\hline C ON C L U SIONS & AN D & POOLICY & SUGGESTIONS & & &
\end{tabular}

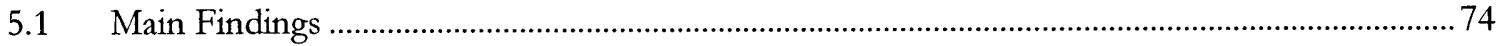

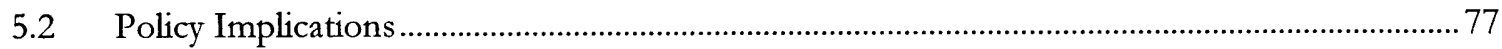

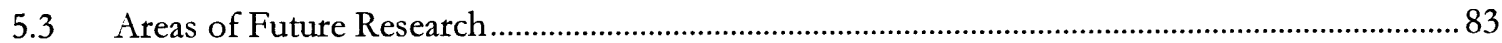

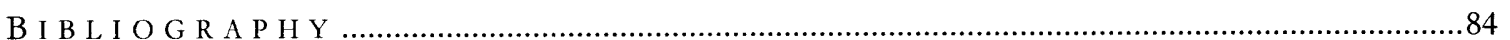

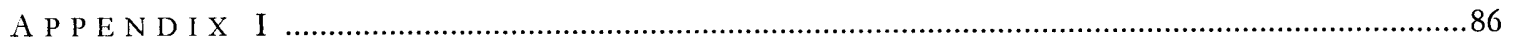

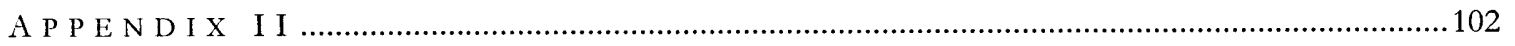

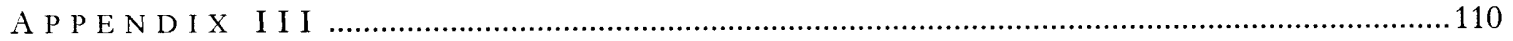

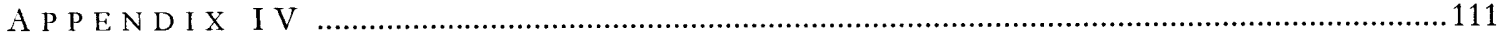

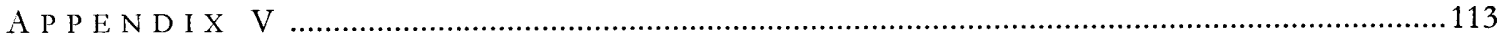

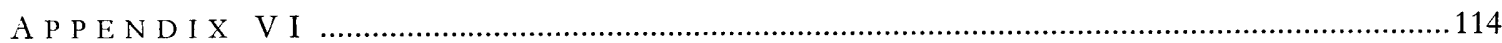

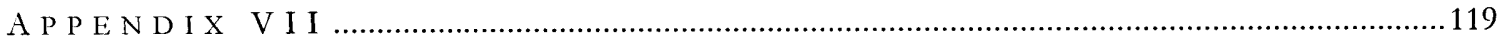

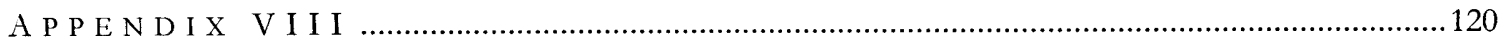




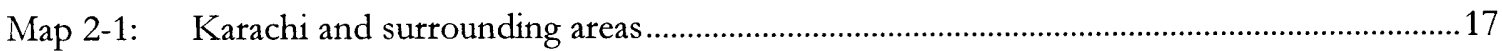

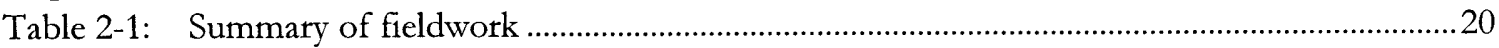

Map 2-2: Location of household and vendor interviews ...................................................................22

Table 2-2: Summary of the socioeconomic characteristic of sample respondents ..............................29

Table 3-1: Households' supplementary sources of water in Karachi...................................................31

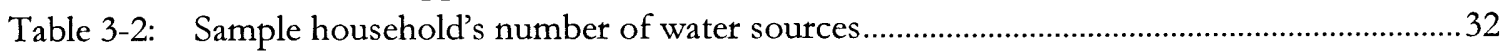

Table 3-3: Overview of the water supply situation of the sample .........................................................32

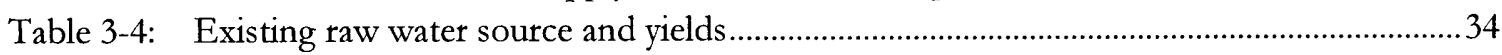

Table 3-5: Overview of KWSB customer profile and service indicators ..............................................36

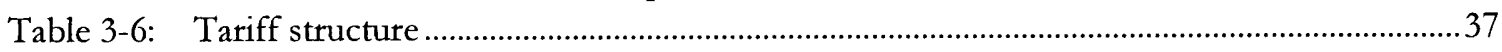

Table 3-7: Future average water demand versus projected supply ........................................................39

Table 3-8: Status of KWSB connection from sample respondents........................................................ 40

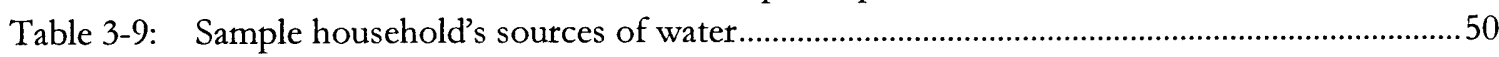

Table 3-10: Sample household's number of water sources.....................................................................51

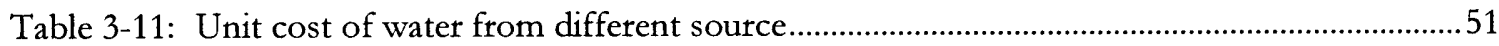

Table 3-12: Level of satisfaction with existing water services .................................................................52

Table 3-13: Perception of public health risk posed by water from different sources.............................53

Table 3-14: Water boiling practices of households .................................................................................53

Table 3-15: An assessment of the amount of money spent by household on water tankers bought and on the water bill.................................................................................................5

Table 3-16: Analysis of water from different sources ..........................................................................5

Figure 4-1: Characterization of the vending industry in Karachi.........................................................58

Table 4-1: Comparison of socioeconomic and demographic characteristic

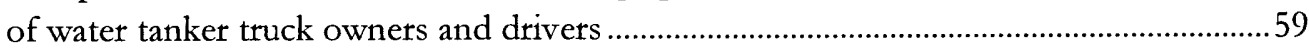

Table 4-2: Tanker truck vendors and their sources of water.................................................................59

Map 4-1: Location of private hydrants and the areas they are servicing ..........................................60

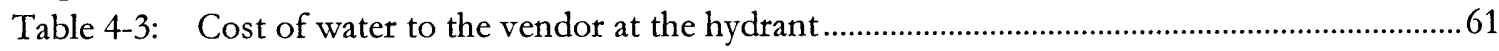

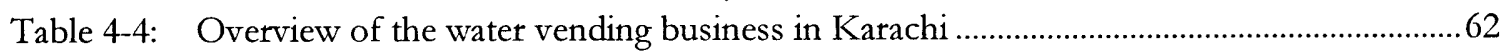

Table 4-5: Price of water for regular and non-regular customers, by season........................................62

Table 4-6: Comparison between water service delivery from KWSB and private hydrant.................63

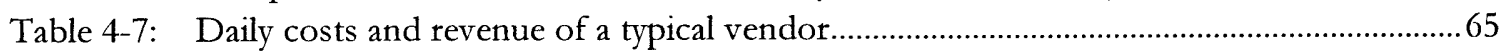

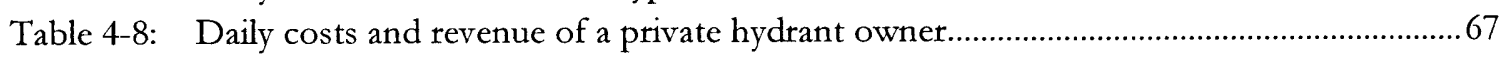

Table 4-9: Schedule of license fee for private sources of water supply ...............................................69

Figure 4-2: Daily money and water transaction in Karachi, Pakistan....................................................71

Figure 5-1: Market share by volume of water....................................................................................

Figure 5-2: Market share by tevenue of water................................................................................. 74 


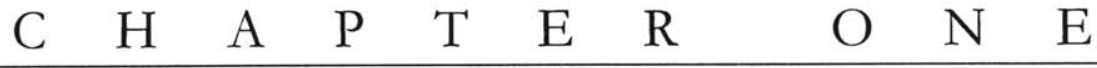 I NTR O DUCTION}
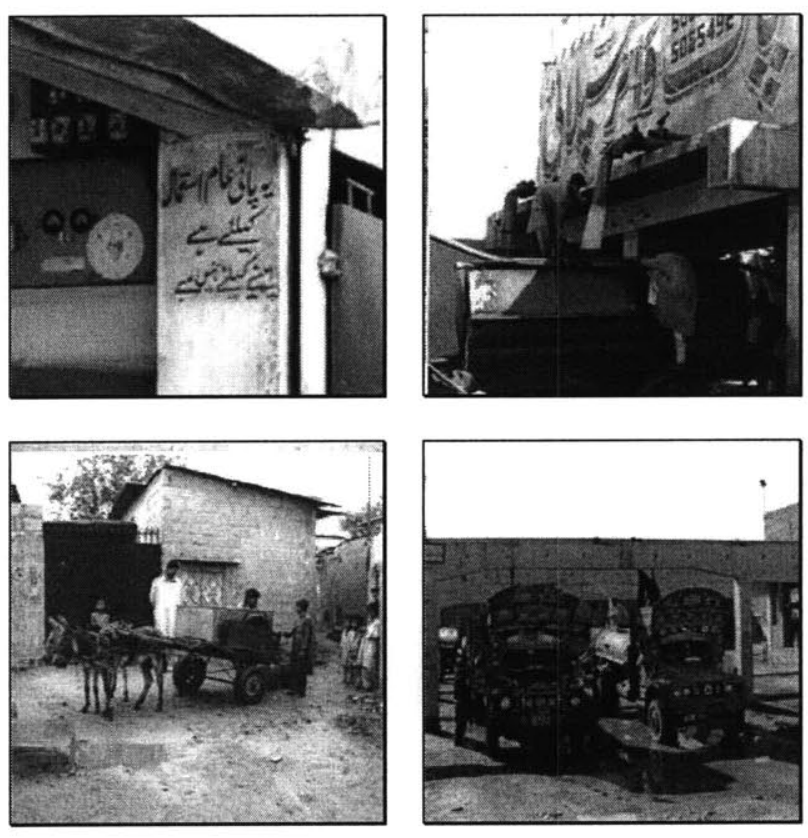


\begin{tabular}{ccccccccccc}
$\mathrm{C}$ & $\mathrm{H}$ & $\mathrm{A}$ & $\mathrm{P}$ & $\mathrm{T}$ & $\mathrm{E}$ & $\mathrm{R}$ & $\mathrm{O}$ & $\mathrm{N}$ & $\mathrm{E}$ \\
\hline
\end{tabular}

In 1995, more than one billion people in low-and middle-income countries-and an additional 50 million people in high-income countries — lacked access to safe water for drinking, personal hygiene and domestic use. This number represents nearly 25 percent of the world's 5.7 billion people. Obtaining water is often particularly difficult and expensive for poor households. In rural areas of developing countries, many women and children spend hours each day — in extreme cases up to six to eight hours — hauling water from rivers or wells. In cities, the poor often do not have water piped into their property. Instead, they must obtain water from other sources, for which they may have to pay three to ten times what piped water costs. ${ }^{1}$

Traditionally, water supply projects in developing countries are comprised of either (a) piped systems with public taps, private household service, or both, or (b) wells with pumps. Recent evidence from developing countries indicates that the water supply sector is still fraught with inefficiencies. Municipal water utilities, which are natural monopolies, ${ }^{2}$ frequently fall into a "low-level equilibrium trap": due to low prices charged, municipalities do not have large sums necessary to invest in expanding and maintaining often decaying infrastructure, and cannot keep pace with the rapid growth of the urban population (Singh $e t$ al., 1993). As a result, water is of unsafe quality, and service is limited, unreliable and inefficient. Large amounts of water, often nearing 50 percent of the supply, are lost in distribution through leaks, and rate collection methods are often are frequently haphazard and highly corrupt (Cowen, 1994). These utilities are also often burdened with oversized staffs of poorly trained employees. These factors, often coupled with the prevalence of subsidies designed to "help" the poor, make for very low levels of cost recovery, thus limiting even further the chance of investment in infrastructure and service improvements (Haarmeyer and Mody, 1998). In sum, the growing administrative and economic inefficiencies of the public utilities have resulted in an inequity of service. Many groups have been left without adequate water connections: low income residents unable to pay the cost

\footnotetext{
${ }^{1} \mathrm{http} / /$ www.worldbank.org/depweb/english/modules/environm/water/index.htm

2 These are goods whose provision requires high average fixed cost and low, or decreasing average variable cost. When several firms compete in the production of such goods, the high fixed costs are unnecessarily multiplied; but when only one firm produces the goods, monopolistic exploitation of consumers will result. The solution to this dilemma is often to provide the goods through a single, public (or publicly regulated) firm whose explicit objective is maximum welfare rather than maximum profit. Drinking water and sewerage systems, with treatment plants, of large minimum efficient scale (MES) and extensive pipe networks, are examples of natural monopolies (Porter et al., 1997).
} 


$\begin{array}{lllllllllll}\mathrm{C} & \mathrm{H} & \mathrm{A} & \mathrm{P} & \mathrm{T} & \mathrm{E} & \mathrm{R} & \mathrm{O} & \mathrm{N} & \mathrm{E}\end{array}$

of connection to the network, people living in geographically remote areas, and people living in illegal squatter settlements (Black, 1998).

However, a third approach of water service delivery in developing countries, seldom recognized or incorporated in design or investment decisions is "water vending". Water vending is the sale and distribution of water by container, ranging from delivery by tanker trucks to the carrying of containers by individuals. The water may be obtained from private or municipal taps, standpoints, rivers or wells, or may be sold either from a public standing station or door-to-door. Vendors may either sell water directly to consumers or act as middlemen, selling water to carriers who in turn serve the consumers. Because of the problems hampering the provision of adequate water services, water vending is ubiquitous in developing countries (Zaroff and Okun, 1984). Vendors are most often patronized when alternative for water supplies are nonexistent, unsanitary or inconvenient As a result, water vending fills a "service gap" in water service delivery systems. (Zaroff and Okun, 1984; Whittington, et al., 1989; Porter, 1996). Thus, poor households who cannot afford private connections to a piped water system often meet their water supply needs through vendors. People living in slums and squatter settlements on the fringes of rapidly expanding urban areas may also rely on vendors until the piped system is extended. Vending is also common in rural areas where piped networks do not exist.

Reliance on water vendors is widespread in cities like Jakarta, Indonesia; Onitsha, Nigeria; Ukunda, Kenya; Portu-au-Prince, Haiti; Khartoum and Port Sudan, Sudan - "Water vendors serve 20 to 30 percent of the urban population of the Third World" (Cairncross, 1990:114), maybe more. However, water-vending delivery has two problems as compared to the piped network delivery. First, distributing water by cart (or by truck) is inefficient as compared to the piped network, and at best a stopgap measure. Second, this inefficiency shows up in the price of vended water: those without household connections (usually the poorer households), end up paying much more then they would for piped water, and so consume much less (Fass, 1982; Cairncross and Kinnear, 1991; Porter, 1996; Whittington et al., 1989; Whittington et al., 1991). For example a study of water vending in Port-au-Prince, Haiti, found that in the dry season many of the urban poor spend $20 \%$ of their income on 


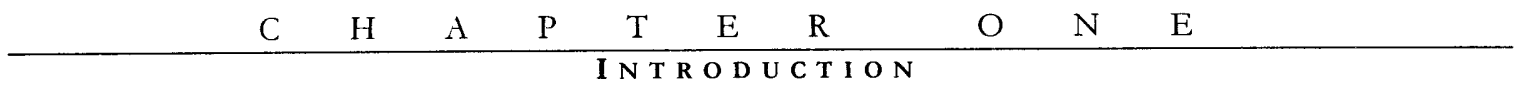

water. In Tegucigalpa, Honduras, poor households spend $8 \%$ of their income on vended water in the rainy season and $12 \%$ in the dry season. In Addis Ababa, Ethiopia, the urban poor spend up to $9 \%$ of their income purchasing water from vendors. ${ }^{3}$

Water vending has both advantages and disadvantages for communities in the developing world. On the positive side, water vending provides a valuable service for communities without access to piped water. The major benefit of water vending to the consumers is that when compared to fetching water from other sources, provides a significant saving of time. Water vending also creates opportunities for employment of unskilled workers. Furthermore, the technologies used in most vending systems are simple and can be maintained locally. Vending operations are less likely to break down than piped systems, however, when they do break down, they can be repaired using local skills, and are thus, technologically more reliable (Rogerson, 1996; Whittington et al., 1989).

On the negative side, households served by vendors often pay higher unit charges for water than they would if they were directly connected to a piped water system. As mentioned earlier, many households pay over ten percent $(10 \%)$ of their monthly income for vended water, as contrasted with between one and five percent $(1-5 \%)$ for piped water. ${ }^{4}$ Another major drawback of vending is the quality of water delivered. Vendors may sell water from polluted sources or fouled containers; even if the initial quality of water is acceptable, water may become contaminated during handling. Water vending can thus also be a health threat to millions of consumers. Furthermore, water vending can be unreliable in its delivery. Vendors may find other lucrative jobs, fall ill, or have family business to attend to; in these cases water is not delivered (Rogerson, 1996; Whittington et al., 1989; Zaroff and Okun, 1984; Crane, 1994).

Another potential drawback of water vending is related to "rent seeking", which is a

\footnotetext{
${ }^{3}$ http://www.worldbank.org/html/fpd/urban/publicat/rd-ou1.html

+ The assumptions relating to the urban and rural water supply are identical; most utilities as well as donors assume that as long as the cost of potable water to the household falls below $5 \%$ of the household income, it is affordable and the household will make the connection to the system and will be able to pay the subsequent and recurrent charge. Water project planning is therefore based on the twin assumption of: a) a very inelastic demand as long as the amount spent on water is below $5 \%$ of the household income; and b) a very elastic demand if the outlay exceeds $5 \%$ of the household income. However, experience of water projects undertaken in many parts of the developing world shows that this 'five percent rule' is often incorrect both for urban and rural areas (Whittington et al., 1990; McPhail, 1993; Rogerson, 1996)
} 


$\begin{array}{llllllllllllllllllll}C & H & A & P & T & E & R & O & N & E\end{array}$

behavioral response of individuals to achieve private gains and has important and pervasive implications for how the water delivery system is designed and operated. Implying that individuals act in ways to create and sustain spatial monopolies in the provision of water from which they can derive private gains, and such rent seeking behavior can have farreaching implications for management of urban water systems (Lovei and Whittington, 1993). An example of such a rent-seeking behavior is observed in the case of Jakarta, Indonesia where the water delivery system is based primarily on public taps, distributing vendors and relatively few household connections. Due to which vendors were earning monopoly rents in their vending territories. The case study shows that nearly half of the average price that customers pay vendors in Jakarta could not only be attributed to the vendor's cost. The implicit wage of vendors in Jakarta was almost 3 times the average wage for men who have not completed secondary school. This discussion indicates that an understanding of the structure of water markets can suggest whether there is a need for reform or lead to policy reforms that can reduce these rents.

However, it is not always the case, that water vendors earn excessive profits. In Ukunda, Kenya, Whittington et al. (1988) found that vended water was costly to provide. This was because hauling water manually was expensive; as a result, vendors were making a fair return on their labor and capital investment, but they were not making exorbitant profits. In such cases, government regulation of distributing vendors is not necessary or advisable.

The literature on water vending advocates public sector intervention in water supply if any of the three conditions exists: First, if vendors are selling contaminated water and households are unaware or unlikely to know the bacteriological content of the water being sold to them. Public health concerns justify intervention. Second, if vendors are charging exorbitant prices, are involved in price fixing, and/or if monopolistic barriers to entry into the water vending industry, government intervention is justified to correct these market inefficiencies. Third, if there is rent seeking happening as a result of inequitable ownership of a water source - for example if all vendors purchase water from a single source controlled by 


\begin{tabular}{cccccccccc}
$\mathrm{C}$ & $\mathrm{H}$ & $\mathrm{A}$ & $\mathrm{P}$ & $\mathrm{T}$ & $\mathrm{E}$ & $\mathrm{R}$ & $\mathrm{O}$ & $\mathrm{N}$ & $\mathrm{E}$ \\
\hline
\end{tabular}

one individual - the vendors' prices to households might be determined in a competitive market while the owner of the source collects monopoly profits (Whittington et al.,1988). ${ }^{5}$

The above discussion brings to perspective the question of whether water vending is 1) a form of water service delivery helpful for improving access by communities in the short term, or 2) a 'problematic' arrangement in which some parties earn excessive profits while at the same time forestalling the development of a community's water sectors. This thesis presents a case study of Karachi, Pakistan, where water vending is widespread and complex, comprising of multiple agents involved in water service delivery.

The case of Karachi poses a challenge to policy makers in water supply planning; a situation where water vending is coexisting with the piped water supply. Almost $50 \%$ of the households with water connections in Karachi are using other informal sources to meet their water supply needs. Almost $18 \%$ of these households are using tanker truck vendors fulfill their demand for water. This situations call for a need to think creatively about vendors and utility and there foreseeable relationship in water supply delivery system.

According to Karachi Water and Sewerage Board (KWSB), the public utility is responsible for producing and supplying water in Karachi and its coverage include $78 \%$ of the households. The rest of the $12 \%$ are serviced either through tanker truck supply regulated by KWSB or standpipes. However, there exist a deficit in the supply and demand for water in the city. Due to this deficit, the average hour of service to households' ranges from 1-4 hours per day throughout the city, this in turn have resulted in dependence of households on vended water to fulfill their primary and supplementary needs throughout the city. The literature on vending falls short on explaining the water-vending situation in Karachi, is water vending a service to households in Karachi and who are these households? Or is it a 'problematic' arrangement and why?

\footnotetext{
${ }^{5}$ For example in Indonesia water vending from a house connection is so profitable that a new house connections are made inordinately expensive in order to maintain the market for the individuals with house connections. In this case the government would be justified in facilitating the provision of more house connections to achieve a more equitable distribution of water resources.
} 


\begin{tabular}{lllllllllllll}
$\mathrm{C}$ & $\mathrm{H}$ & $\mathrm{A}$ & $\mathrm{P}$ & $\mathrm{T}$ & $\mathrm{E}$ & $\mathrm{R}$ & $\mathrm{O}$ & $\mathrm{N}$ & $\mathrm{E}$ & \\
\hline I N T R O D U C T I O N &
\end{tabular}

Furthermore, In recent studies (Crane, 1994; Fass, 1988; Lovei and Whittington, 1993; Whittington et al., 1989; Whittington et al., 1991), somewhat less space has been devoted to the study of water delivery systems across income groups, especially in the context of water vending. Most of the recent literature has placed due importance to the poor and their access to water in the urban areas, using assumptions that water vending can be, and is a valuable service for the poor in urban and peri-urban areas. However, systematic assessments of how urban water policies affect vending and other water sources, cutting across income groups are rare. ${ }^{6}$ To examine this gap the study looks at variations and the extent of dependence on vended water across income groups in Karachi.

The objectives of the thesis are:

1) To characterize the existing water supply situation in Karachi, with particular focus on the water vending industry;

2) To evaluate the extent to which water vending in Karachi affects the households' water supply situation and generates excessive profits for vendors; and

3) To assess possible strategies for reform of Karachi's water sector.

This document is organized into five chapters. Each chapter examines one aspect of the water supply situation in Karachi and the conclusion brings together the complete picture and attempts to answer the question, "What should be the nature of public intervention in the vending industry for Karachi?"

Following this introduction, Chapter Two provides a brief overview of Karachi, outlines the study methodology adopted, and describes the socioeconomic characteristics of the households interviewed. Chapter Three uses the findings of household surveys to examine the current water supply situation in Karachi. Chapter Four focuses on the water vending industry in Karachi and delineates the distinction between the private "providers" and "distributors" of water. It concentrates on primary vendors, which include tanker truck and hydrant owners. This chapter also provides and analysis of the daily water distribution in Karachi from all public and private sources. This analysis takes into account not only the

\footnotetext{
${ }^{6}$ Recent examples include Linn (1983) and Kasarda and Parnell (1993) on large cities; Schteingart (1989) on Latin America;
} Marcussen (1990), Jellinek (1991) and Crane (1994) on Jakarta; and Fass (1988) on Haiti. 


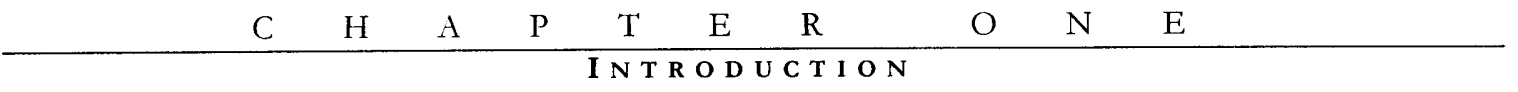

volume of water but also the movement of revenue spent by households on water on a daily basis. Most of the information in this chapter is based on empirical data gathered during fieldwork in Karachi. Finally, Chapter Five summarizes the key findings of the study and sets the stage for policy recommendations. 


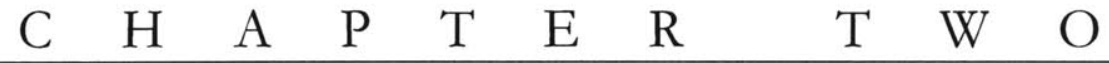

OVERVIEW OF KARACHI AND STUDY APPROACH
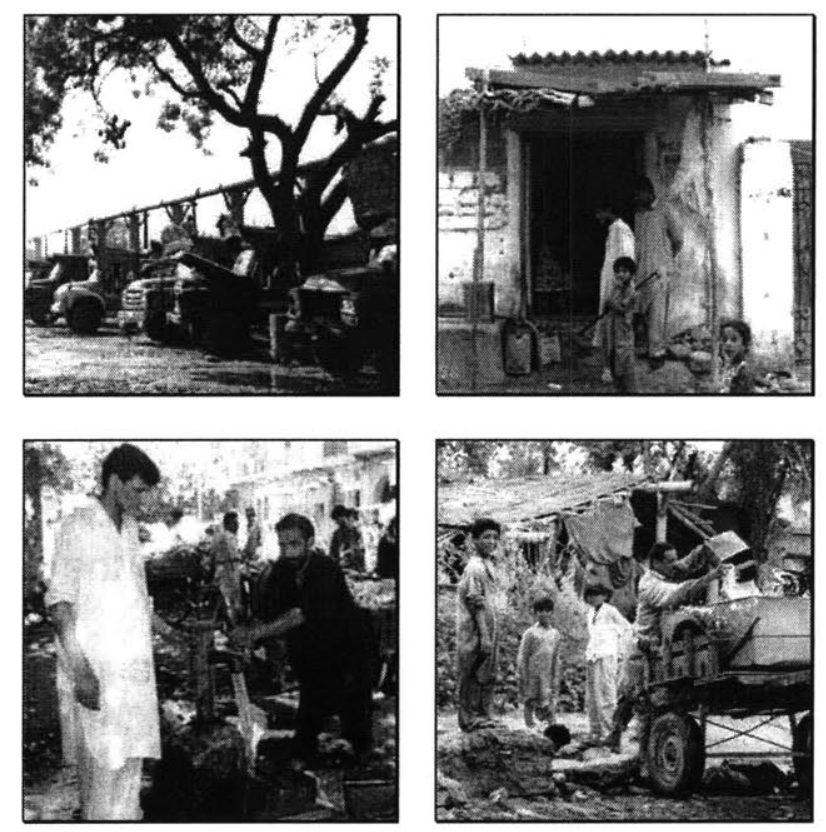


$\begin{array}{llllllllll}C & H & A & P & T & E & R & T & W & O\end{array}$

\subsection{Introduction to Karachi}

Karachi is the capital city of the Sindh province and the largest city in Pakistan, covering almost 1.97 million hectares of land area. Situated on the eastern coast of the Arabian Sea and to the northwest of the Indus River, Karachi is Pakistan's only port city (Map 2-1).

Karachi has an arid climate with an average annual rainfall of approximately $200 \mathrm{~mm}$ (8 inches). Annual rainfall, however, varies widely and can be as much $800 \mathrm{~mm}$ ( 32 inches). Undulating plains and coastal flats devoid of vegetation characterize the region's typography. The Lyari and Malir Rivers cut across the city; these rivers only flow for short periods of the year and for the rest of the time are recipients of the city's wastewater.

Karachi has a population of 10.3 million, ${ }^{7}$ which accounts for $8.6 \%$ of all inhabitants of Pakistan. Furthermore, the metropolis is being "fed by the process of urbanization": $27 \%$ of the urban population of the country lives in Karachi. ${ }^{8}$ The annual growth rate for the city presently stands at $4.8 \%$, of which $2.6 \%$ is due to natural growth and $2.2 \%$ is due to migration from other parts of the country. Karachi's population growth rate is much higher than the national average of $2.9 \%$ per year (Hasan, 1998).

The land area of the city comprises both planned areas, developed by the Karachi Development Authority (KDA), and katchi abadis, settlements formed through land invasion (squatting) and illegal subdivision of state land. The katchi abadis are initially unserviced and acquire services slowly over a period of time. Approximately $40 \%$ of Karachi's population (4.1 million people) lives in these katchi abadis (Hasan, 1998).

Almost $30 \%$ of all land use in Karachi is residential and $12 \%$ is industrial (KDA, 1991). Approximately $63 \%$ of households live in single or multiple unit detached houses, and 37\% live in apartments or high rise buildings in Karachi (Hasan, 1994).

\footnotetext{
7 The population figure for Karachi is very controversial; it ranges from anywhere between 10 to 14 million in different credible citations. However, 11.5 million is the population estimate quoted in most of KWSB's publication. For the purpose of this research, the study assumes the current population to be 10.3 million as cited from a recently published work. Any data cited from KWSB sources was based on population estimates of 11.5 million people.

8 Ahmad, K.B., Karachi in Chaos, papet contributed in UIA XVI Congress
} 


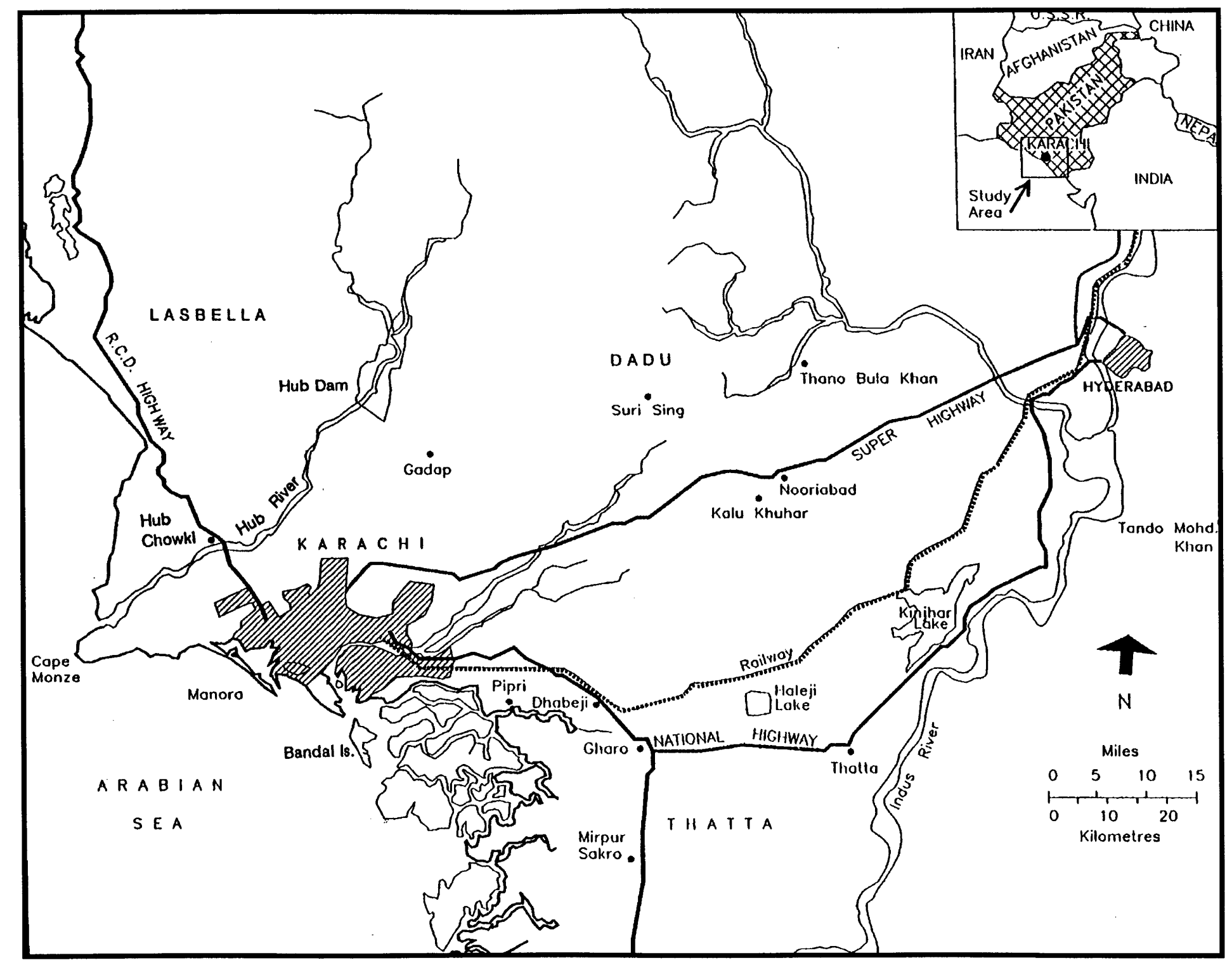

Map 2-1: Karachi and Surrounding Areas

Source: Karachi Development Plan 2000 - Karachi Development Authority 


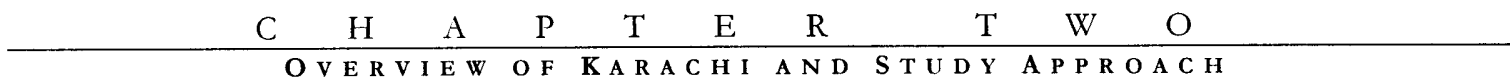

The economy of Karachi is mainly based on trade and industry. Karachi provides $25 \%$ of federal revenues and 15\% of Pakistan's Gross Domestic Product (GDP) and is the country's most industrialized city. In addition, $50 \%$ of the country's bank deposits and $72 \%$ of all issued capital comes from Karachi (Hasan, 1998). Karachi also accounts for $42 \%$ of overall value added, $35 \%$ of employment in large-scale manufacturing, and $42 \%$ of tax revenues nationally. GDP per capita for Karachi is estimated to be more than US $\$ 1,200$. With only about $35 \%$ of the provincial population, Karachi provides over $73 \%$ of the average daily reported manufacturing employment in Sindh, and accounts for over $70 \%$ of value added in manufacturing and over $60 \%$ of Sindh's estimated Gross Regional Product (GRP) (World Bank, 1993). These data demonstrate the political and economic importance of Karachi for the province of Sindh as well as Pakistan overall.

A significant proportion of employment in Karachi is provided by the informal sector. In 1995, the informal sector provided 75\% of Karachi's employment as compared to $48 \%$ of the total jobs in 1974. (Hasan, 1994).

\subsection{The Water Supply Situation in Karachi}

Karachi's water supply delivery system consists of both formal and informal service provisions, as is common in many developing countries. Formal delivery is managed by the Karachi Water and Sewerage Board (KWSB), responsible for water and sanitation service delivery in Karachi. Private entrepreneurs throughout the city, who operate as "providers" and "distributors" of water, conduct informal water service delivery. "Providers" bore deep holes in the ground on private property, creating "private hydrants" from which they extract ground water to sell commercially. "Distributors" can be classified as primary and secondary vendors who distribute water throughout the city to households and industries. Primary vendors include bulk distributors who obtain water from the point source of the utility, private hydrants, or tanker trucks, which deliver water throughout the city. Secondary vendors operate mostly at the neighborhood level; water is delivered by donkey carts, neighbors, push carts, bhistee (manual water carrier), or at kiosks. Public and private wells are also common sources of water supply at the household and neighborhood levels. 


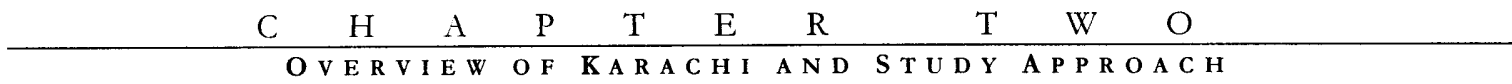

\subsubsection{Key Stakeholder in Water Service Delivery}

The Karachi Water and Sewerage Board (KWSB), formed in 1983, is an autonomous body under the Government of Sindh and is responsible for providing water and sewerage infrastructure to the Karachi metropolitan area. KWSB supplies water mainly through a piped network, standpipes, and regulated tanker truck delivery. KWSB customer records indicate that approximately 8.5 million people ( $78 \%$ of the total population) in Karachi are served by the water supply network. Another 1.7 million customers receive water from standpipes or tanker trucks regulated by KWSB. The utility, however, currently collects only about $23 \%$ of the amount it bills customers for these services. ${ }^{9}$ Although there are no reliable estimates of how much of the population is connected to the sewerage network, anecdotal reports suggest that about $40 \%$ of the population is connected (KWSB, 1997). The KWSB and other water supply providers are described in further detail in Chapter 3.

Karachi Metropolitan Corporation (KMC) holds the status of a city government. KMC has overall policy control and responsibility for public health (control of infectious diseases), medical services, fire services, social welfare, physical and town planning, building control, regularization of katchi abadis, municipal police, and civil defense management over Karachi's metropolitan area. In 1998, KMC's Public Health Division enacted the "Control and Regulation of Hydrant by-laws", requiring all private hydrants to be registered with the KMC. Owners of the private hydrants must pay a license fee, the amount of which depends on the mechanical power of the engine used for extracting the groundwater. After requisite procedures are followed to gauge quality of water, $\mathrm{KMC}$ has total discretion as to whether to approve the private hydrant source for drinking or non-drinking purposes. Despite these bylaws, only 25 private hydrants are registered with KMC, and many illegal (unregistered) hydrants and vendors continue to operate in the city.

According to a survey conducted by KMC, there are approximately 106 large, medium and small sized private water hydrants spread throughout Karachi. In response to KMC's hydrant by-laws, the Hydrant Owners' Association was formed by private hydrant

\footnotetext{
${ }^{9}$ KWSB - Basic Facts $1998-99$
} 


$\begin{array}{llllllllllllll}C & \mathrm{H} & \mathrm{A} & \mathrm{P} & \mathrm{T} & \mathrm{E} & \mathrm{R} & \mathrm{T} & \mathrm{W} & \mathrm{O}\end{array}$

OVERVIEW OF KARACHI AND STUDY APPROACH

owners to provide themselves with the required institutional support to deal with KWSB and other government agencies challenging their status. They do not have office premises; the current chairman of the organization, also a hydrant owner, manages most of its affairs.

The Karachi Water Tanker Owners' Welfare Association was formed in 1987 to provide institutional support to tanker truck owners, who suffer from police and KWSB's harassment due to their illegal status. Membership requires payment of a small monthly fee that covers the costs of running the organization. According to the organization's president, in 1998 it had a membership of 5000, and there are approximately 4000 tanker trucks operating in Karachi. These tanker trucks make approximately 50,000 trips per day and move 50 million gallons per day (MGD) from the private hydrants in the city. ${ }^{10}$

\subsection{Methodology}

This thesis is based on review of secondary data and empirical evidence gathered over five weeks of fieldwork in Karachi. The fieldwork was carried out during January and February of 1999.

\section{Table 2-1: Summary of Fieldwork}

\begin{tabular}{|c|c|c|c|}
\hline & \multicolumn{2}{|c|}{ Respondents } & Number of interviews \\
\hline \multirow{4}{*}{ Structured interviews } & \multicolumn{2}{|l|}{ Household members } & 40 \\
\hline & \multirow{3}{*}{ Vendor Interviews } & Tanker truck owners & 17 \\
\hline & & Tanker truck drivers & 17 \\
\hline & & Hydrant owners & 9 \\
\hline \multirow{3}{*}{$\begin{array}{l}\text { Semi-structured } \\
\text { discussions }\end{array}$} & \multicolumn{2}{|c|}{ KWSB/KMC officials } & 12 \\
\hline & \multicolumn{2}{|c|}{ Concerned affiliates / organizations } & 8 \\
\hline & & Total & 103 \\
\hline
\end{tabular}

A total of 103 interviews were conducted with members of key stakeholder groups involved in water supply delivery in Karachi. Of the 103 interviews, 83 were structured interviews with vendors and households and 20 were semi-structured discussions with

10 Personal interview with Mr. Haji Muhammad Younus Khan, President, Karachi Water Tanker Association - January 1999. 


$\begin{array}{llllllllll}\mathrm{C} & \mathrm{H} & \mathrm{A} & \mathrm{P} & \mathrm{T} & \mathrm{E} & \mathrm{R} & \mathrm{T} & \mathrm{W} & \mathrm{O}\end{array}$

institutional stakeholders. During July and August of 1998, two weeks of prior field observations were conducted in Karachi (Table 2-1). ${ }^{11}$

\subsubsection{Households Interviews ${ }^{12}$}

Household interviews were conducted in both planned areas and katchi abadis in Karachi. A sample was selected to reflect a cross-section of the income groups in the city. The author's past experience of the city was helpful in identifying areas where different income groups live. ${ }^{13}$ Once an area had been selected, contact was made with neighborhood committees and household interviews were conducted in that area.

Due to time and resource constraints, a street sampling strategy was employed in each of the four neighborhoods. Three main lanes in each area were selected, and about three households were interviewed in each lane. The selected lanes were not located in close proximity to one another, but were distributed spatially across the neighborhood.

Households in the lane were selected such that they were well distributed along the lane (i.e. every tenth house in a lane of 30 houses - either on the right or left). No preset considerations, such as whether the head of the household was male or female, or whether the interviewee was male or female, influenced the selection of the household for an interview. Everyone in the household is assumed to be in some way involved in and aware of their current water supply situation.

Forty household survey interviews were conducted, ten each in four income-groups, in four different localities of the city (Map 2-2). The 16-page survey includes questions about the residents' current water sources, storage capacity, boiling and sanitation practices, as well as socioeconomic and demographic characteristics of household members. ${ }^{14}$

11 The outcome of the field observations was submitted as a draft field note document to UNDP-World Bank Regional Water and Sanitation Program - South Asia (RWSG-SA).

12 See Appendix 1 for copy of the household survey

13 Areas in the city in which to conduct household interviews, as explained in the main text, was determined on the basis of the author's past experience of the city; the author was raised and has lived her whole life in Karachi. Personal and professional contacts with different neighborhood social organizations further facilitated selecting areas in which to carry out interviews.

1+ The surveys used in the field for this research was based on the format of rapid reconnaissance surveys used in water vending activities and willingness to pay studies. The past water vending studies (i.e. Onitsha, Nigeria) suggests that rapid reconnaissance surveys yield valuable data for policy development and planning. Studies such as this are inexpensive relative to the capital costs of urban watts, and should be a standard part of water supply project design and planning in developing country (Whittington et al., 1991). 


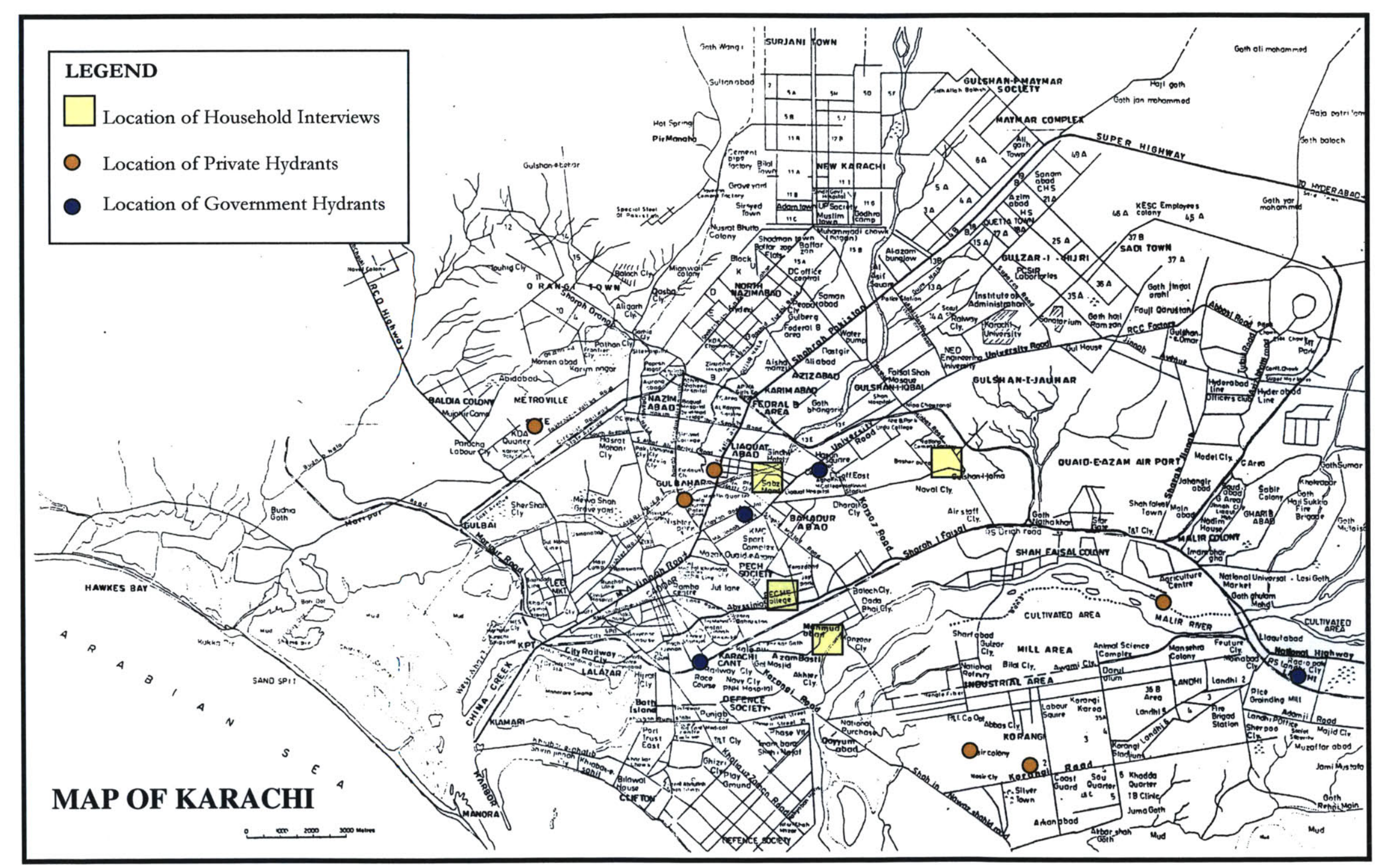

Map 2-2: Location of Household and Vending Interviews

Source: Urban Resource Center, Karachi 


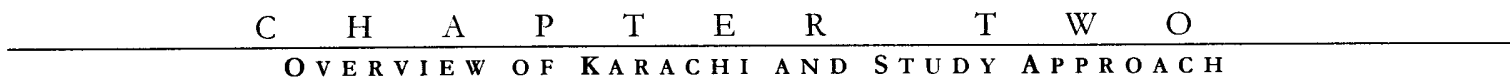

Household interviews were clustered primarily in the southeastern part of the city, which is primarily residential (Map 2-2). A brief description of each area selected and interviewed is given below.

Mujahid Colony is a katchi abadi, located in the eastern part of the city that started as an illegal subdivision but is now in the process of legalization. $70 \%$ of the houses, however, already have leases. The area comprises mostly single unit family, detached houses. Plot sizes in the area are generally less than 100 square yards (mostly 60 and 80 square yards). Although the area is partially formally connected to the networked water supply, many of the households have also connected illegally to the KWSB main line. The area nevertheless suffers from chronic and acute shortages of water.

Mehmoodabad is located in the southern part of the city and can be categorized as a low-income area. The neighborhood is predominantly comprised of single unit, ground, and two story houses on plot sizes ranging from $60-120$ square yards. The area is connected to the piped network, but water vending, using donkey carts and tanker trucks, is common.

PIB colony is located on the eastern side of the city. It is a planned middle-income area with single unit, detached, introverted houses, each overlooking a courtyard. Plots in the area range from 180 - 400 square yards. Until several months ago (summer 1998) the area faced an acute water shortage problem and most households preferred to use government tankers to meet this deficit. However, the water shortage in the area has improved since a new trunk line was laid in the area, improving the supply and distribution of water.

Pakistan Employees Cooperative Housing Society, commonly known as PECH Society, is located on the eastern side of the city. PECHS ranks among Karachi's oldest affluent areas. Plot sizes in the area range from 500-2000 square yards. Most of the houses are single-unit, and are located on a large plot of land, with large lawns and porches. ${ }^{15}$ However, recent urbanization has impacted this neighborhood in the form of apartment buildings and business plazas, which are found on the fringes. All houses are connected to

\footnotetext{
15 The building by-laws applicable in the neighborhood allow $1 / 3$ covered area of the plot and $2 / 3$ open; as a result, the
} houses in this neighborhood have big lawns and porches. 


\begin{tabular}{rccccccccc} 
C & H & A & P & T & E & R & T & W & O \\
\hline O V E R VIIE W & O F & K A R A C H I & A N N D & S T U D Y & A P P R O A C H
\end{tabular}

the piped water network system. In a recent survey carried out by the Neighborhood Committee (NC) in the area, water supply was indicated as a top priority for residents. ${ }^{16}$

\subsubsection{Vendor Interviews ${ }^{17}$}

Forty-three vendor surveys were completed, which included interviews with seventeen tanker truck drivers, seventeen tanker truck owners, and nine hydrant owners. A nine-page questionnaire was used to collect detailed information about the different sources of water, the number of trips per day, cost and expenditure information, and the areas where service is provided. The hydrant owners were asked about their initial capital investment, the amount of water sold daily, and information related to their daily costs and expenditures (Table 2-1).

Interviews were conducted with vendors at ten different water hydrant locations in the city. Of these, four were government hydrants (LSR-Civic Center, Muslimabad, Clifton and Jamia Millia) and six were private hydrants (TeenHaiti, Landhi, Site, Malir, Lasbella) (Map 2-2).

Government hydrant locations are easily identifiable in the city because there are only six and commercial sale of water is only allowed at one. On the basis of this information, four government hydrants were selected, the largest one being the one where commercial sale is permitted. Interviews with private hydrant owners started from one cluster in the Center City known as "Teen Haiti," famous in the city as a water source. Through interviews with hydrant and tanker truck owners, other potential clusters of private hydrants were identified in the city. Following up on this information, visits were made to these areas and interviews were conducted at another five-cluster location of private hydrants.

\footnotetext{
${ }^{16}$ A survey was conducted by Citizen Police Liaison Committee- Neighborhood Committee (CPLC-NC), a coalition of police and residents of PECH Society in 1996. Almost $88 \%$ of households that responded stated that the water supply issue as an important concern in the neighborhood and suggested involvement of the NC to address this issue in its future activities.

${ }^{17}$ See Appendix II for copy of the vendor survey
} 


\begin{tabular}{rrrrrrrrrr}
$C$ & $H$ & A & P & T & E & R & T & W & O \\
\hline O V V E R V I E W & O F & K A R A C H I & A N D & S T U D Y & A P P R OA C H
\end{tabular}

Most of the interviews with tanker truck drivers and owners were held either at the government or private hydrant locations in the city. The strategy adopted for interviews was to approach any tanker truck vendor waiting for his truck to be filled with water. This approach generated a sample, which included tanker truck vendors who were government contractors, those who were only buying water from the private hydrants, and those who were doing both.

Hydrant owner interviews were carried out in the 6 clusters of private hydrants. It was observed that most of the private hydrants have an office on their premises. The strategy adopted was to visit several offices in each cluster. If someone with knowledge about the day-to-day operation of the hydrant was available, then an interview was conducted. If the owner was not available, the person responsible for running the day to day operation of the hydrant was interviewed.

\subsubsection{KWSB/KMC Officials Interviews}

Semi-structured discussions were held with officials of KWSB to understand institutional perspectives of the water supply situation in the city and to gather information about plans for improvements. These meetings were held with different groups of people in the organizational hierarchy in management, operation and maintenance, and supply and distribution. These discussions formed the basis for understanding KWSB's contractual and commercial arrangements with tanker truck owners regarding usage and sale of water from the government hydrants.

The Director of Health at KMC was also interviewed as private hydrants in Karachi fall under this organization's jurisdiction. This discussion yielded information about the existing bylaws that are relevant to hydrant regulation (Table 2-1).

\subsubsection{Concerned Affiliates/Organizations}

Interviews were held with organizations representing the interests of the hydrant owners, tanker truck owners, neighborhoods where household interviews were conducted, 


\begin{tabular}{cccccccccc}
$\mathrm{C}$ & $\mathrm{H}$ & A & P & T & E & R & T & W & O \\
\hline O V E R V I E W & O F & K A R A C H I & A N D & S T U D Y A P P R OAC A
\end{tabular}

and institutions and individuals involved in the water sector in Karachi. The purpose of these meetings was to extend the understanding of institutional arrangements that exist between the different stakeholders involved in water service delivery and to collect secondary data in the form of published reports. Meetings with neighborhood organizations prior to household interviews established a preliminary understanding of the nature and extent of the water supply problems at the neighborhood level. In addition, they facilitated access to households in the neighborhood for interviews (Table 2-1).

\subsection{Secondary Data Review}

Another important source of data for this thesis was the Water Loss Reduction and System Strengthening Project - Consumer Survey $1996 .{ }^{18}$ This study was conducted by Mott McDonalds International, Limited, in association with Associated Consulting Engineers (Pvt.) Ltd., MM Pakistan (Pvt.) Ltd., and Thames Water, UK. The data set from the study includes 2051 observations and covers the whole of the Karachi metropolitan region. The survey used included questions about the households' current water supply situation. ${ }^{19}$

Other literature used in this research includes the Karachi Water and Sewerage Board's Basic Facts, which is published annually. Other sources include World Bank Staff appraisal reports and ancillary data gathered from KWSB, the Karachi Municipal Corporation (KMC), and neighborhood committees.

\subsection{Limitation of the Study - Caveats}

This study does not provide a statistically significant picture of the households and informal private providers (vendors). Instead, it provides a snapshot of the current water supply situation of Karachi both from the demand (households) and supply (KWSB \& informal private providers) perspectives. A possible focus for further research is the political economy of water, which is not the focus of this thesis, but it does influence how water is

\footnotetext{
${ }^{18}$ See Appendix III for copy of the consumer survey questionnaire

19 The data set is primarily used to illustrate the different sources which households in Karachi are using to meet their water needs; distinction is made with those with a water connection and those without one.
} 


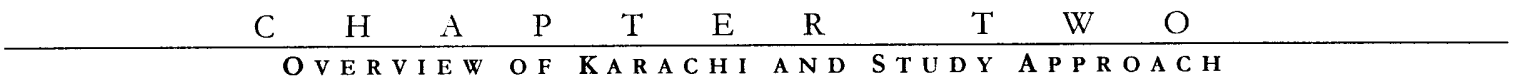

valued in Karachi. Other issues related to water supply and associated services that have not been examined in depth could also be an area for further research. For instance, additional research can be conducted to determine whether there is any connection between the level of sanitation and the sources of water used by households, or whether there is an informal sector providing sanitation services to households.

Not much attention has been paid to the social benefits of the water vending industry from income and employment generation perspectives. From the study, it is understood that the vending industry in Karachi provides many job opportunities to unskilled labor, both directly and indirectly (due to the spillover effect of activities i.e., mechanics, tire repair and paint stores). However, the vending industry has not been considered in its entirety as generator of employment and social mobility.

This study identifies secondary vendors as important players in the informal water service delivery sector at the neighborhood level. It provides a description of different forms of secondary vendors who service the sample households. However, it does not deal with this sector in as much detail as it does primary vendors. Furthermore, individual solutions to the water supply situation, such as public or private wells and informal resale by neighbors, have not been considered in detail.

\subsection{Socioeconomic Characteristics of the Sample Respondents}

Of the 40 households interviewed, $67 \%$ of the respondents were male and $33 \%$ female. Of the households that responded, almost $15 \%$ were headed by females. The average age of the respondent for the sample was 38 years. Almost $65 \%$ of the respondents were married.

The average number of persons per household for the sample was 8.3 . About $5 \%$ of the respondents had no formal education; 3\% had completed primary school; $23 \%$ had completed secondary school; $10 \%$ had completed high school; $45 \%$ had completed a university degree; and 14\% had completed some secondary school education. All respondents are Muslims. 


\begin{tabular}{cccccccccc}
$\mathrm{C}$ & $\mathrm{H}$ & A & P & T & E & R & T & W & O \\
\hline O OVE R VI E W & O F & K A R A C H I & A N D & S T U D Y & A P P R OA C H
\end{tabular}

Approximately $55 \%$ of the households live in single family, detached houses, while $45 \%$ live in multi-family houses. Thirty-six \% of the households in this sample live in houses with just a ground floor, $46 \%$ live in ground plus one-story houses, and $18 \%$ live in houses with two stories or more. Only $5 \%$ of the households in the sample responded that they have a commercial establishment on the premises.

All the households that responded have electricity and their average monthly bill is PKR. 2182.0 (\$41.6). Gas, which is available in abundance in Pakistan, is the primary cooking fuel for $97 \%$ of the households. $95 \%$ of the households in the sample have private water sealed toilets and are connected to the sewerage system, either through a closed underground drainage system or an open drainage system.

The sample response indicated that the average daily wage rate for an unskilled laborer in Karachi is PKR.141.0 (\$2.7) (Table 2-2).

The survey was held in three distinct income groups in the city, as explained in the earlier section. To verify these categories, self-reported estimates of income, plot size, market value of the house, expected rent per month and asset ownership were solicited from the households.

Eleven percent of the sample population has fewer than three assets; $;^{20} 90 \%$ have three or more assets. Of the households interviewed, $92 \%$ live in owned houses and $8 \%$ in rental units. This outcome is very similar to that observed in the Water Loss Reduction and System Strengthening Project in which $92.5 \%$ of respondents were owners and $7.5 \%$ were renters.

The plot size of the households ranges from 60 to 2000 square yards. The expected monthly rent of the respondents in the sample ranges from PKR. 600 (\$11.5) to 80,000 $(\$ 1526.7)$ per month. The market value of the houses in the sample ranged from PKR.

\footnotetext{
${ }^{20}$ The question asked if households owned any of the following: radio, telephone, bicycle, television, sewing machine, motorcycle, telephone, television, motorcycle, satellite dish, mobile phone, automobile.
} 


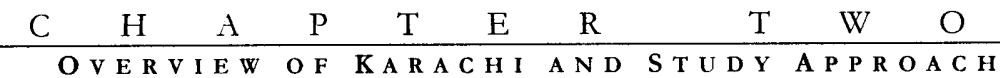

$80,000(\$ 1526.7)$ to $40,000,000(\$ 763,358.7)$. The disparities between the different income groups are very distinct (Table 2-2).

Table 2-2: Summary of the Socioeconomic Characteristics of Sample Respondents

\begin{tabular}{|c|c|c|c|c|c|}
\hline & $\begin{array}{c}\text { Full } \\
\text { Sample }\end{array}$ & $\begin{array}{c}\text { High } \\
\text { Income } \\
\end{array}$ & $\begin{array}{l}\text { Middle } \\
\text { Income } \\
\end{array}$ & $\begin{array}{c}\text { Low } \\
\text { Income } \\
\end{array}$ & $\begin{array}{l}\text { Katchi } \\
\text { Abadis }\end{array}$ \\
\hline Number of households & 40 & 11 & 10 & 10 & 9 \\
\hline \multicolumn{6}{|l|}{ Gender of respondent } \\
\hline Male & $\begin{array}{c}27 \\
(67.5 \%) \\
\end{array}$ & $\begin{array}{c}7 \\
(64 \%) \\
\end{array}$ & $\begin{array}{c}8 \\
(80 \%) \\
\end{array}$ & $\begin{array}{c}5 \\
(50 \%) \\
\end{array}$ & $\begin{array}{c}7 \\
(78 \%) \\
\end{array}$ \\
\hline Female & $\begin{array}{c}13 \\
(32.5 \%) \\
\end{array}$ & $\begin{array}{c}4 \\
(36 \%) \\
\end{array}$ & $\begin{array}{c}2 \\
(20 \%) \\
\end{array}$ & $\begin{array}{c}5 \\
(50 \%) \\
\end{array}$ & $\begin{array}{c}2 \\
(22 \%) \\
\end{array}$ \\
\hline Average age of respondent (years.) & 38 & 50.4 & 32.4 & 34.3 & 34.5 \\
\hline \multicolumn{6}{|l|}{ Marital status } \\
\hline Single & $\begin{array}{c}14 \\
(35 \%) \\
\end{array}$ & $\begin{array}{c}1 \\
(9 \%) \\
\end{array}$ & $\begin{array}{c}6 \\
(60 \%) \\
\end{array}$ & $\begin{array}{c}5 \\
(50 \%) \\
\end{array}$ & $\begin{array}{c}2 \\
(22 \%) \\
\end{array}$ \\
\hline Martied & $\begin{array}{c}26 \\
(65 \%) \\
\end{array}$ & $\begin{array}{c}10 \\
(91 \%) \\
\end{array}$ & $\begin{array}{c}4 \\
(40 \%) \\
\end{array}$ & $\begin{array}{c}5 \\
(50 \%) \\
\end{array}$ & $\begin{array}{c}7 \\
(78 \%) \\
\end{array}$ \\
\hline \multicolumn{6}{|l|}{ Occupancy status } \\
\hline Owned & $\begin{array}{c}36 \\
(92.0 \%) \\
\end{array}$ & $\begin{array}{c}10 \\
(91 \%) \\
\end{array}$ & $\begin{array}{c}9 \\
(90 \%) \\
\end{array}$ & $\begin{array}{c}9 \\
(100 \%) \\
\end{array}$ & $\begin{array}{c}8 \\
(89 \%) \\
\end{array}$ \\
\hline Rental & $\begin{array}{c}3 \\
(8 \%) \\
\end{array}$ & $\begin{array}{c}1 \\
(9 \%)\end{array}$ & $\begin{array}{c}1 \\
(10 \%) \\
\end{array}$ & $\begin{array}{c}0 \\
(0 \%) \\
\end{array}$ & $\begin{array}{c}1 \\
(11 \%) \\
\end{array}$ \\
\hline Average household size (persons) & 8.3 & 7.2 & 8.5 & 8.7 & 8.8 \\
\hline Households with electricity & 40 & 11 & 10 & 10 & 9 \\
\hline Average electricity bill per month (PKR.) & $\begin{array}{l}2182.0 \\
(\$ 41.6) \\
\end{array}$ & $\begin{array}{c}6111.1 \\
(\$ 116.6) \\
\end{array}$ & $\begin{array}{r}1037.5 \\
(\$ 19.8) \\
\end{array}$ & $\begin{array}{l}504.4 \\
(\$ 9.6) \\
\end{array}$ & $\begin{array}{l}325.0 \\
(\$ 6.2) \\
\end{array}$ \\
\hline Average household income (PKR.)/month & $\begin{array}{c}31,560 \\
(\$ 602.3) \\
\end{array}$ & $\begin{array}{c}90,000 \\
(\$ 1717.6)\end{array}$ & $\begin{array}{c}24,400 \\
(\$ 465.7) \\
\end{array}$ & $\begin{array}{c}10,000 \\
(\$ 190.8) \\
\end{array}$ & $\begin{array}{c}5,000 \\
(\$ 95.4) \\
\end{array}$ \\
\hline Asset ownership & 5 & 8 & 6 & 4 & 3 \\
\hline Average plot size (square yards) & 587 & 1606 & 205 & 114 & 72 \\
\hline Average market value of the house (PKR.) & $\begin{array}{l}7,773,333 \\
(\$ 148,346) \\
\end{array}$ & $\begin{array}{l}23,250,000 \\
(\$ 443,702) \\
\end{array}$ & $\begin{array}{l}1,988,889 \\
(\$ 37,955) \\
\end{array}$ & $\begin{array}{c}670,000 \\
(\$ 12,786) \\
\end{array}$ & $\begin{array}{l}463,333 \\
(\$ 8,842) \\
\end{array}$ \\
\hline $\begin{array}{l}\text { Average expected monthly rental for the house } \\
\text { (PKR.) }\end{array}$ & $\begin{array}{c}14,467 \\
(\$ 276.1) \\
\end{array}$ & $\begin{array}{c}56,000 \\
(\$ 1068.7) \\
\end{array}$ & $\begin{array}{c}7,111 \\
(\$ 135.7) \\
\end{array}$ & $\begin{array}{r}3,657 \\
(\$ 69.8) \\
\end{array}$ & $\begin{array}{r}3,500 \\
(\$ 66.8) \\
\end{array}$ \\
\hline
\end{tabular}

Source: Fieldwork, January 1999

This chapter presents a background to the city of Karachi and the adopted study methodology with a brief description of the various stakeholders involved in water service delivery. The chapter that follows describes the current water supply situation in Karachi in the context of 'formal' and 'informal' water service delivery provisions, using the data from households' survey to understand the nature of the demand for different forms of water supply in Karachi. The chapter then examines water demand, using data from the household surveys. 


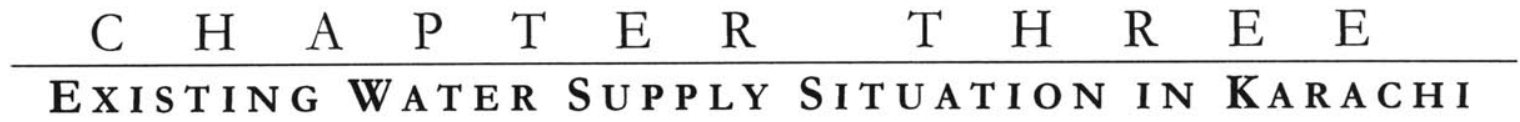
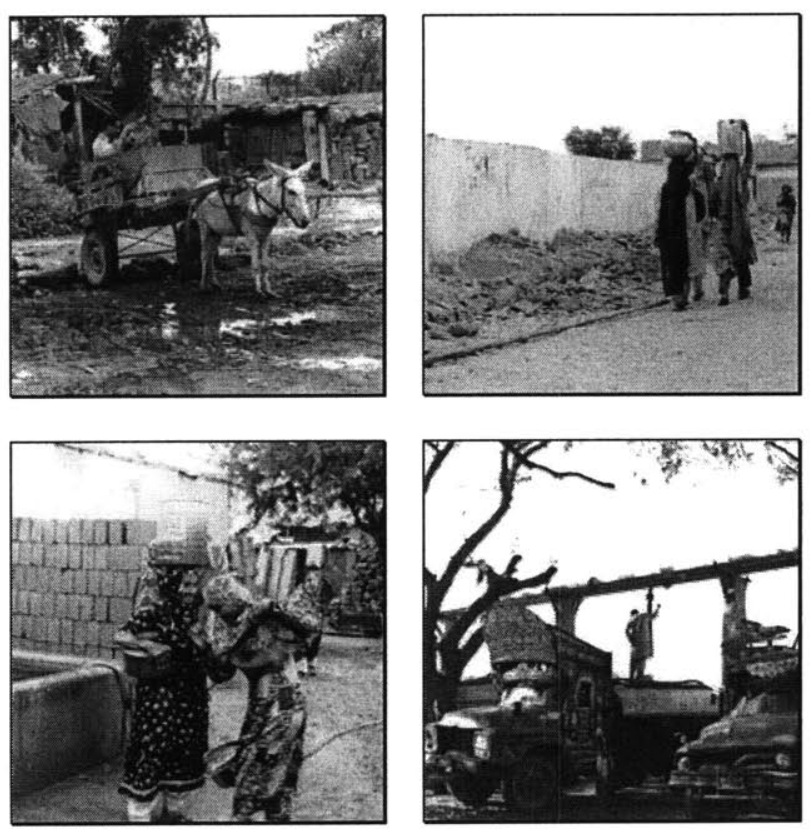


$\begin{array}{llllllllllll}\mathrm{C} & \mathrm{H} & \mathrm{A} & \mathrm{P} & \mathrm{T} & \mathrm{E} & \mathrm{R} & \mathrm{T} & \mathrm{H} & \mathrm{R} & \mathrm{E} & \mathrm{E}\end{array}$

\subsection{Introduction}

Almost $78 \%$ of Karachi's households receive water through a conventional piped network system managed by the Karachi Water and Sewerage Board (KWSB). ${ }^{21}$ However, the Water Loss Reduction and System Strengthening Project Consumer Survey (1996) suggests that many households in Karachi are also using other sources of water to meet their water needs. The sample included 1969 households with and 93 without private water connections. The survey was conducted with 2062 households throughout Karachi, and indicates that $49 \%$ of those surveyed and were connected to the piped network were use only their household connection for water supply, whereas $51 \%$ use other sources in addition to their pipe connection. Water supply delivered tanker trucks is most common supplementary water source to households with connections. For the $4.5 \%$ of households not connected to the pipe network, standpipes ${ }^{22}$ and private wells are the main sources of water supply (Table 31).

\section{Table 3-1: $\quad$ Households' Supplementary Sources of Water in Karachi}

\begin{tabular}{|c|c|c|c|c|}
\hline \multirow{2}{*}{ Sources of Water } & \multicolumn{2}{|c|}{ With Water Connection } & \multicolumn{2}{|c|}{ With No Water Connection } \\
\hline & Winter $^{1}$ & Summer $^{2}$ & Winter & Summer \\
\hline \multirow{2}{*}{ KWSB } & 966 & 561 & - & - \\
\hline \multirow{2}{*}{ Water Tankers } & $(49.1 \%)$ & $(28.5 \%)$ & 11 \\
& 338 & 546 & 13 & $(11.8 \%)$ \\
\hline Standpipes & $(17.2 \%)$ & $(27.8 \%)$ & $(14.0 \%)$ & 34 \\
\hline Public Wells & 144 & 291 & 34 & $(36.6 \%)$ \\
\hline Private Wells & $(7.3 \%)$ & $(14.8 \%)$ & $(36.6 \%)$ & 1 \\
\hline Vendors & 82 & 95 & 1 & $(1.1 \%)$ \\
\hline Neighbors & $(4.2 \%)$ & $(4.8 \%)$ & $(1.1 \%)$ & 25 \\
& $(8.7 \%)$ & $(172 \%)$ & $(25.8 \%)$ & $(26.9 \%)$ \\
\hline & 33 & 50 & 4 & 3 \\
& $(1.7 \%)$ & $(2.5 \%)$ & $(4.3 \%)$ & $(3.2 \%)$ \\
\hline
\end{tabular}

1 This estimate assumes seven months of dry weather of off peak season for winters from September to March

2 This estimate assumes five months of peak season for summers from April to August

${ }^{3}$ Includes both donkey carts and kiosk vendors

Source: Water Loss Reduction and System Strengthening Project Consumer Survey (1996)

21 KWSB, 1999. Water Supply System of Karachi - Database 1999

22 Standpipe provision falls within KWSB services 


$\begin{array}{lllllllllllll}C & H & A & P & T & E & R & T & H & R & E & E\end{array}$

ExISTING WATER SUPPLY SITUATION IN KARACHI

Use of supplementary water sources by households connected to the KWSB network varies according to season. During winter months, roughly half of households with private water connections use one additional water source on a regular basis; during summers months this fraction rises to three-quarters. These additional water sources include tanker trucks, kiosks and donkey carts, neighbors, and public and private wells.

Table 3-2: $\quad$ Sample Household's Number of Water Sources

\begin{tabular}{|c|c|c|c|}
\hline & Number of Sources & Winter $^{1}$ & Summer $^{2}$ \\
\hline \multirow[t]{4}{*}{ KWSB Connection } & Only KWSB connection & $\begin{array}{c}966 \\
(49.1 \%)\end{array}$ & $\begin{array}{c}561 \\
(28.5 \%)\end{array}$ \\
\hline & KWSB connection and one other source & $\begin{array}{c}943 \\
(47.9 \%) \\
\end{array}$ & $\begin{array}{c}1235 \\
(62.7 \%) \\
\end{array}$ \\
\hline & KWSB connection and two other sources or more & $\begin{array}{c}60 \\
(3.0 \%)\end{array}$ & $\begin{array}{c}173 \\
(8.8 \%)\end{array}$ \\
\hline & TOTAL & $\begin{array}{c}1969 \\
(100 \%)\end{array}$ & $\begin{array}{c}1969 \\
(100 \%)\end{array}$ \\
\hline \multirow[t]{3}{*}{ No KWSB Connection } & Only one source & $\begin{array}{c}80 \\
(86.0 \%)\end{array}$ & $\begin{array}{c}78 \\
(83.9 \%)\end{array}$ \\
\hline & Two sources or more & $\begin{array}{c}13 \\
\left(14.0^{\circ} \%\right)\end{array}$ & $\begin{array}{c}15 \\
(16.1 \%)\end{array}$ \\
\hline & TOTAL & $\begin{array}{c}93 \\
(100 \%)\end{array}$ & $\begin{array}{c}93 \\
(100 \%)\end{array}$ \\
\hline
\end{tabular}

${ }_{1}^{1}$ This estimate assumes seven months of dry weather of off peak season for winters from September to March

2 This estimate assumes five months of peak season for summers from April to August

Source: Water Loss Reduction and System Strengthening Project Consumer Survey (1996)

Table 3-3: Overview of the Water Supply Situation of the Sample

\begin{tabular}{|c|c|c|}
\hline Number of household surveyed & \multicolumn{2}{|c|}{2062} \\
\hline Percentage of households with water connection & \multicolumn{2}{|c|}{$95.5 \%$} \\
\hline Percentage of households with water storage facilities & \multicolumn{2}{|c|}{$71.1 \%$} \\
\hline Avetage duration of water supply during winter & \multicolumn{2}{|c|}{$3.0 \mathrm{hrs}$} \\
\hline Average duration of water supply during summer & \multicolumn{2}{|c|}{$2.8 \mathrm{hrs}$} \\
\hline \multirow[t]{2}{*}{$\begin{array}{l}\text { Percentage of households that say they received sufficient supply of } \\
\text { water from their private connection... }\end{array}$} & in winter & in summer \\
\hline & $\begin{array}{c}869 \\
(44.1 \%)\end{array}$ & $\begin{array}{c}530 \\
(26.9 \%)\end{array}$ \\
\hline
\end{tabular}

Source: Water Loss Reduction and System Strengthening Project Consumer Survey - 1996

The data in table 3-3 suggests that the water supply needs of many households' with connections to the KWSB network are unmet. This conclusion is supported by additional information from the consumer survey (Table 3-3). For example, among the households 
\begin{tabular}{llllllllllll}
$\mathrm{C}$ & $\mathrm{H}$ & $\mathrm{A}$ & $\mathrm{P}$ & $\mathrm{T}$ & $\mathrm{E}$ & $\mathrm{R}$ & $\mathrm{T}$ & $\mathrm{H}$ & $\mathrm{R}$ & $\mathrm{E}$ & $\mathrm{E}$ \\
\hline
\end{tabular}

EXISTING WATER SUPPLY SITUATION IN KARACHI

with a private water connection, the average number of hours of service per day was only 3.0 during winter months and 2.8 during summer months. This is the average number of hours that water is actually flowing into the pipe connection. Seventy-three percent and $56 \%$ of households indicated that the amount of water they received from their connection was not sufficient for their needs in summer and winter, respectively.

Water sources in Karachi can be categorized as formal or informal means of water supply service delivery. Formal water supply options includes all services that fall under the responsibility of KWSB. Informal water supply options includes those services beyond KWSB's scope. Each of these sources is described in greater detail below.

\subsection{Formal Water Supply Services-KWSB}

The Karachi Water and Sewerage Board (KWSB) supplies water to its consumers through three principal sources: a piped network, standpipes and tanker trucks that deliver water to areas not served by the piped system. KWSB's customer records indicate that approximately 8.5 million of the 11.5 million residents of Karachi are connected to the water supply network. Another 1.7 million customers receive water from standpipes or tankers regulated by KWSB (KWSB, 1997). Overall KWSB serves $78 \%$ of Karachi's total population from one or more of these three sources. ${ }^{23}$

KWSB was created as a semi-autonomous body in 1979 through an amendment to the Sindh Local Government Ordinance. KWSB was formed as a subsidiary of the Karachi Municipal Corporation (KMC) ${ }^{24}$ and was delegated the responsibility for providing water and sewerage infrastructure to the Karachi metropolitan area. The KMC exercised control over KWSB staff salaries, tariffs, and the appointment of top management. However, in 1996, KWSB was separated from Karachi Municipal Corporation (KMC) and became an autonomous body under direct control of the Government of Sindh (GoS). Since then the appointment of the Chairman, are in the hands of GoS.

\footnotetext{
${ }^{23}$ There exists a discrepancy in the figures, 8.5 of 11.5 million equals $74 \%$ coverage. Whereas, according to official KWSB figures it has service coverage of $78 \%$. Both these figures are from KWSB official source. However, they don't add up. ${ }^{24} \mathrm{KMC}$ is the largest city government in Pakistan, has the status of a metropolitan corporation, given this status in 1976.
} 


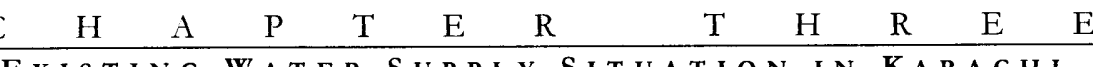

KWSB is based on a centralized and hierarchical organizational model. The highest power rests with the Managing Director, who directly reports to the Chairman of the Board appointed by the Government of Sindh (GoS). Since 1996, this position of the chairman has been vacant. KWSB is organized into five main departments, each headed by a Deputy Managing Director (DMD), who directly reports to the Managing Director. A high level of discretion rests with these DMDs.

The total staff of KWSB is approximately 11,600 , with 10,000 employed by the technical services department alone. The current staff to connection ratio is approximately 17:1000, which is higher than other cities in the region (e.g. Manila, Tianjan, Dehli Bangkok, Shanghai, Honk Kong and Seoul) (ADB, 1997).

\subsubsection{Piped Network}

\section{a) Sources of Water}

The River Indus, located approximately $120 \mathrm{~km}$ east of Karachi, is the principal source of raw water for the city. Other smaller sources include the Hub River to the north and Dumlotte ground water wells to the northeast (table 3-4). In all, $99 \%$ of the water distributed by KWSB comes from surface sources, while only $1 \%$ is ground water (map 2-1). A detailed description of these sources is provided in appendix 4.

Table 3-4: $\quad$ Existing Raw Water Source and Yields

\begin{tabular}{|l|c|}
\hline Source & Yield (MGD) $^{\mathbf{1}}$ \\
\hline Dumlottee Wells & 4 \\
\hline Indus Source & 421 \\
\hline Hub Source & 100 \\
\hline & Total \\
\hline
\end{tabular}

${ }^{1}$ Million gallons per day (MGD)

Source: Private Sector Participation in KWSB - Draft Feasibility Report (1997)

\section{b) Water Distribution}

There are only 24 bulk meters installed along the main distribution network but only three of these are operational. It is therefore difficult to estimate volume of water moving around the system or to reliably quantify the volume of unaccounted for water (UAW). 


$\begin{array}{lllllllllllll}\mathrm{C} & \mathrm{H} & \mathrm{A} & \mathrm{P} & \mathrm{T} & \mathrm{E} & \mathrm{R} & \mathrm{T} & \mathrm{H} & \mathrm{R} & \mathrm{E} & \mathrm{E}\end{array}$

EXISTING WA TER SUPPLY SITUATION IN KARACHI

However, according to KWSB's estimate almost $37 \%$ of the water put into the supply, leaks from the distribution system. This figure is comparable to other cities in Asia and Pacific Region. $^{25}$

The degraded condition of the distribution infrastructure is due to poor quality materials and construction techniques used in joint and service connections. Furthermore, the water distribution system is complex and highly vulnerable; minor setbacks disrupt supply to large areas and major breakdowns can paralyze the whole system. Failure of power supply and lack of standby power source available with KWSB often cause disruption in supply. ${ }^{26}$ Pressure in the water distribution system is generally low. Low or negative pressure in main pipes causes groundwater leakage into the system and occasional water contamination.

\section{c) Customer Profile}

KWSB's records indicate that approximately 8.5 million people are connected to the water supply network. Another 1.7 million customers receive water from standpipes or tankers regulated by KWSB. Approximately 1.4 million people obtain water by other means (i.e., illegal connections, supplies from unregulated tankers). However, as seen from the data presented in Table 3-1 and 3-2, households use multiple sources of water in Karachi Although, there are no reliable estimates of how much of the population is connected to the sewerage network, anecdotal reports suggest that it is about 40\% (KWSB, 1997).

In many parts of the city, water is unavailable for long periods each day due to supply rotation and ad hoc valving procedures. ${ }^{27}$ The poor service capacity due to low average volumes of water available to the population is made worse by inequitable distribution due to outside (political) interference and theft from the system (illegal

${ }^{25}$ Cities with comparable unaccounted for water $(\mathrm{UAW})$ in Asia and Pacific Region i.e. Bombay (24\%), Dehli (30\%), Calcutta (36\%), Colombo (51\%), Dhaka (62\%) as reported in the Second Water Utilities Data Book - Asia and Pacific Regions - 1997 - An Asian Development Bank Publication

26 PSP-KWSB Strategy Report, 1997

${ }^{27}$ Due to rationing in the supply of water, a valving system in the tertiary distribution is in place, a mechanism in the distribution system that allows for control of supply monitored by the employee of KWSB. 


$\begin{array}{llllllllllll}\mathrm{C} & \mathrm{H} & \mathrm{A} & \mathrm{P} & \mathrm{T} & \mathrm{E} & \mathrm{R} & \mathrm{T} & \mathrm{H} & \mathrm{R} & \mathrm{E} & \mathrm{E}\end{array}$

EXISTING WATER SUPPLY SITUATION IN KARACHI

connections), the effects of which cannot be quantified..$^{28}$ As a result, $40 \%$ of water flow is classified as non-revenue water for KWSB (ADB, 1997).

Table 3-5: Overview of KWSB Customer Profile and Service Indicators

\begin{tabular}{|c|c|}
\hline Indicators & Value \\
\hline Population & 11.5 million \\
\hline Households (7 person/household) & $1,642,857$ \\
\hline Connections 1997-98 & $1,106,836$ \\
\hline Connected & 785,665 \\
\hline Unconnected & 321,171 \\
\hline Public yap 100 persons/PT & 10,000 \\
\hline Average daily production & $488 \mathrm{MGD}$ \\
\hline Water loss due leakage @ 37\% ${ }^{29}$ & $135 \mathrm{MGD}$ \\
\hline Service coverage & $78 \%$ \\
\hline Water availability & $1-4 \mathrm{hours} / \mathrm{day}$ \\
\hline Average per capita consumption of water & $21 \mathrm{~g} / \mathrm{c} / \mathrm{d}$ \\
\hline
\end{tabular}

Source: Water Supply System Database 1999

Average domestic per capita consumption is estimated to be $21 \mathrm{~g} / \mathrm{c} / \mathrm{d}$ for households connected to the distribution system and 10 gallons per capita per day $(\mathrm{g} / \mathrm{c} / \mathrm{d})$ for customers who receive water via standpipes or tankers. However, this calculation does reflect water consumption of households using multiple sources.

Around $50 \%$ of the people who receive water via connection to the water distribution system or via standpipes are in low socioeconomic category. Two thirds of the people who obtain water by other means also fall in this category. ${ }^{30}$

\section{d) Tariff Levels ${ }^{31}$}

The current average water tariff based on domestic bulk consumption amounts to PKR. $11.5(\$ 0.22) / \mathrm{m}^{3}{ }^{32}$ This cost includes water and sewerage charges, as well as a fire tax, which is based on a percentage of net annual rental value (NARV). KWSB has two types of tariff - one for households connected to the piped network and another for unconnected households. Connected customers pay the tariff and receive water supply at their homes.

${ }^{28}$ Areas where residents have a political clout have a better level of service, compared to other areas.

${ }^{29}$ This value has been understated the UAW has been calculated on the basis of current supply being 365MGD

${ }^{30}$ Private Sector Participation in KWSB - Strategy Report - February 1997

31 Dollar (\$) are US dollars throughout the document. Unless noted otherwise, I use the exchange rate in effect in January 1999 which equalled US $\$ 1.00=$ PKR. 52.4

32 Based on domestic bulk supply of PKR. 44/1000 gallons 


$\begin{array}{lllllllllllll}C & H & A & P & T & E & R & T & H & R & E & E\end{array}$

EXISTING WATER SUPPLY SITUATION IN KARACH I

Unconnected customers also have to pay a tariff to KWSB to obtain water from a public standpipe located close to their dwelling or through regulated water tankers. Table 3-5 briefly explains the current tariff structure, and the tariff document is provided in Appendix 5. Currently KWSB has 785 thousand customers with connections and 321 thousand customers without connections (KWSB, 1997).

As many as 300,000 connections exists that are not on KWSB's current billing record, as of the most recent database review 1984, the record has not been updated since. Supplies to domestic customers are not metered; the tariff for water and sewerage services is not based on volumetric consumption, but rather on the plot size and covered area of the property. Bulk supplies (both domestic and commercial/industrial) are metered, with a volumetric tariff in place.

\section{Table 3-6: $\quad$ Tariff Structure ${ }^{1}$}

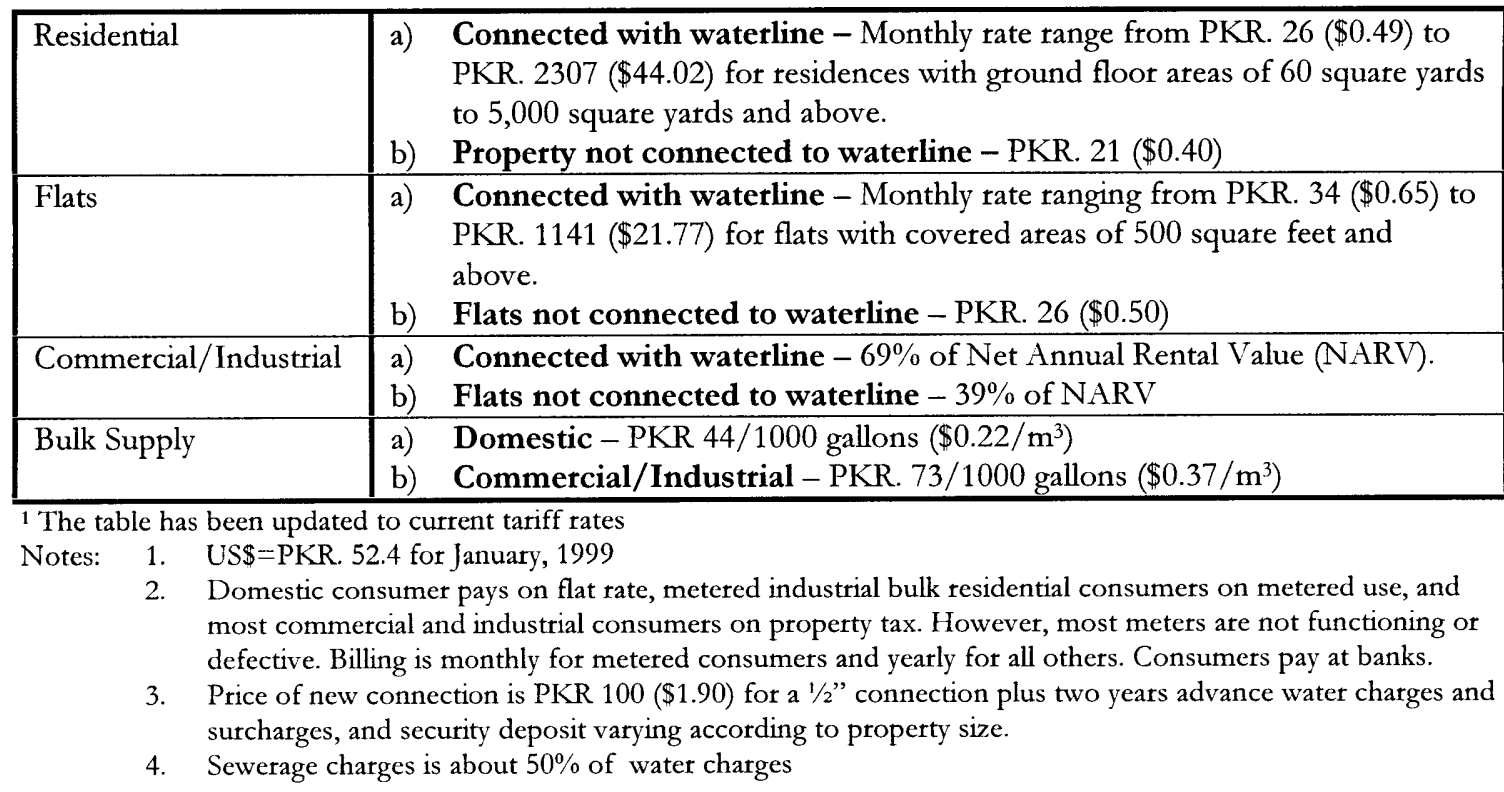

Source: Second Water Utilities Data Book - Asian Development Bank (1997)

The last tariff increase was implemented in July 1998. It is reported in the Private Sector Participation in KWSB, 1997 - strategy document that, except bulk customers, this increase has had a negative impact on the collection rate. Only around two percent $(2 \%)$ of 


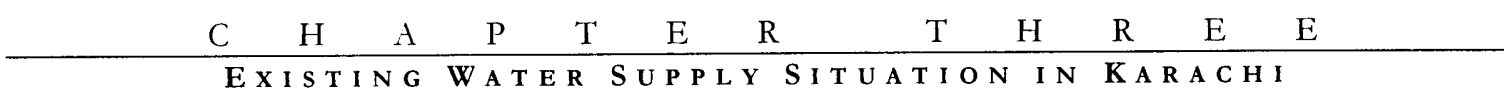

the average household income is spent on water and sanitation services even after the tariff increase, as against a generally accepted benchmark of five percent $(5 \%) .^{33}$

\section{e) Financial Performance}

The KWSB strategy is to keep tariffs low and cover costs through a combination of revenues and subsidies. However, KWSB's cash flow situation has deteriorated in the past couple of years and its operating shortfall has increased to reach PKR. $489 \mathrm{~m}(\$ 12.2 \mathrm{~m})$ in 1994-95. There are many reasons for KWSB's operating shortfall: low tariff levels and inadequate increases over time, bill collection rates of only $23 \%$, as well as loss of earnings due to illegal connections and tanker deliveries, increase in overall operating costs due to physical leakage in the system, high power costs per cubic meter billed as a result of poor maintenance, obsolescence of plant and equipment, and physical losses, in addition to the high establishment cost (the cost of personnel represents some $37 \%$ of the operating expenditure) $)^{34}$ have all contributed to the deteriorating financial situation of KWSB (KWSB, 1997).

As a result, KWSB is in deep financial crisis and is in the process of exploring options such as private sector participation in water and sanitation with the support of the World Bank.

\section{f) Existing and Projected Supply and Demand of Water}

As shown in table 3-7, the gap between demand for water and KWSB's supply capacity is expected to widen in the coming decade as a result of industrial growth, population growth, changes in standard of living, and changes in the effectiveness of the transmission and distribution system.

In the last couple of years, most of the capital investment from the Government of Sindh (GoS) or donor support (World Bank/ADB) has been directed mainly toward upgrading the infrastructure, increasing water supply from the Indus River, water loss reduction and institutional restructuring programs.

\footnotetext{
${ }^{33}$ See footnote 4 in Chapter 1

${ }^{34}$ Quoted as 54\% in Second Water Utilities Data Book - ADB Publication - 1997
} 


$\begin{array}{lllllllllllll}\mathrm{C} & \mathrm{H} & \mathrm{A} & \mathrm{P} & \mathrm{T} & \mathrm{E} & \mathrm{R} & \mathrm{T} & \mathrm{H} & \mathrm{R} & \mathrm{E} & \mathrm{E}\end{array}$

Table 3-7: Future Average Water Demand versus Projected Supply

\begin{tabular}{|c|c|c|c|}
\hline Year & Demand (MGD) & Supply (MGD) & Shortfall (MGD) \\
\hline 1997 & 680 & 388 & 292 \\
\hline 2000 & 820 & 494 & 320 \\
\hline 2010 & 1338 & 594 & 744 \\
\hline
\end{tabular}

Source: Report compiled by the World Bank in collaboration with the Sindh Government. Also published in NEWSLINE, November, 1997

\section{g) Sample Household Response to KWSB connection}

Approximately $73 \%$ of responding households have a working water connection,

$13 \%$ have a non-working water connection and $15 \%$ have no water connection. Most of the households without water connections are from katchi abadis. Roughly, $17 \%$ of the respondents are connected illegally to the network; their reported reason for connecting illegally was that the utility had not been able to extend the network main, so they have extended the connection from their household to the network main. Almost $67 \%$ of the respondents said they use suction pumps to siphon water from the main during the hours of supply; this practice is least prevalent in high-income households. Although, it is not legal to use suction pumps for water, and there is a penalty for their use, its prevalence and use among households is widespread. The suction pump costs on average PKR. 2700 (\$51.5). The average supply to households is 1.5 hours on the days they received water, which is much lower than the 2.9 hours average indicated in the Water Loss Reduction and System Strengthening Project Consumer Survey - 1996.

Approximately $45 \%$ of the respondents indicated that they were getting water every other day, $9 \%$ said they got water every day, another $9 \%$ said that they got water once or twice a week, and $6 \%$ said that the supply was inconsistent. On average $67 \%$ of the sample households responded that their need were being met by the water supplied through the network. ${ }^{35}$

\footnotetext{
35 This is a calculated average of a question that asked households to approximate how much of their total consumption was being met by this source. A percentage was assigned to these selections and the average is the outcome over all households who responded to the question.
} 


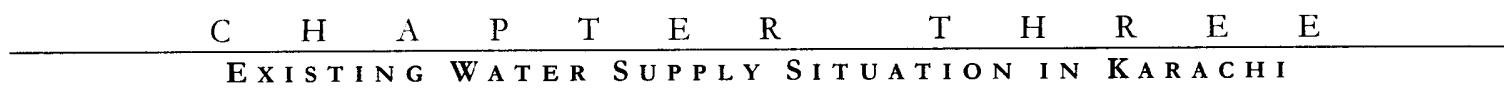

Almost $70 \%$ of the households that responded said they received a bill annually and $18 \%$ said that they received a bill biannually. My interviews at KWSB also suggest that billing of water and conservancy charges are biannual. Almost $80 \%$ of the respondents said that they always paid the water bill, which is very high as compared to KWSB's collection rate, $23 \%$.

Table 3-8: $\quad$ Status of KWSB Connection from Sample Respondents

\begin{tabular}{|c|c|c|c|c|c|}
\hline & $\begin{array}{c}\text { Full } \\
\text { Sample }\end{array}$ & $\begin{array}{c}\text { High } \\
\text { Income }\end{array}$ & $\begin{array}{l}\text { Middle } \\
\text { Income }\end{array}$ & $\begin{array}{c}\text { Low } \\
\text { Income }\end{array}$ & $\begin{array}{l}\text { Katchi } \\
\text { Abadis }\end{array}$ \\
\hline Households have working water connection & $\begin{array}{c}29 \\
(73 \%)\end{array}$ & $\begin{array}{c}8 \\
(73 \%)\end{array}$ & $\begin{array}{c}10 \\
(100 \%)\end{array}$ & $\begin{array}{c}8 \\
(80 \%)\end{array}$ & $\begin{array}{c}3 \\
(33 \%)\end{array}$ \\
\hline Households have non working water connection & $\begin{array}{c}5 \\
(13 \%) \\
\end{array}$ & $\begin{array}{c}3 \\
(27 \%) \\
\end{array}$ & $\begin{array}{c}0 \\
(0 \%) \\
\end{array}$ & $\begin{array}{c}2 \\
(20 \%) \\
\end{array}$ & $\begin{array}{c}0 \\
(0 \%) \\
\end{array}$ \\
\hline Households having no water connection & $\begin{array}{c}6 \\
(15 \%) \\
\end{array}$ & $\begin{array}{c}0 \\
(0 \%) \\
\end{array}$ & $\begin{array}{c}0 \\
(0 \%) \\
\end{array}$ & $\begin{array}{c}0 \\
(0 \%) \\
\end{array}$ & $\begin{array}{c}6 \\
(67 \%) \\
\end{array}$ \\
\hline Households having illegal connection & $\begin{array}{c}6 \\
(17 \%)\end{array}$ & $\begin{array}{c}0 \\
(0 \%)\end{array}$ & $\begin{array}{c}0 \\
\left(0^{\circ} \%\right)\end{array}$ & $\begin{array}{c}1 \\
(10 \%)\end{array}$ & $\begin{array}{c}5 \\
(100 \%) \\
\end{array}$ \\
\hline Average hours of supply to households & 1.5 & 2.0 & 1.9 & 0.8 & 0.4 \\
\hline Households using suction pump for water & $\begin{array}{c}22 \\
(67 \%)\end{array}$ & $\begin{array}{c}3 \\
(27 \%)\end{array}$ & $\begin{array}{c}9 \\
(90 \%)\end{array}$ & $\begin{array}{c}7 \\
(70 \%) \\
\end{array}$ & $\begin{array}{c}3 \\
(100 \%) \\
\end{array}$ \\
\hline$\%$ of water need of household met by KWSB & $67 \%$ & $56 \%$ & $86 \%$ & $63 \%$ & $58 \%$ \\
\hline Average KWSB household bill for the year $(\mathrm{PKR} .)^{1}$ & $\begin{array}{c}5,755 \\
(\$ 109.8)\end{array}$ & $\begin{array}{c}11,250 \\
(\$ 214.7)\end{array}$ & $\begin{array}{c}2,450 \\
(\$ 46.8)\end{array}$ & $\begin{array}{c}2,283 \\
(\$ 43.6)\end{array}$ & -2 \\
\hline
\end{tabular}

1 These are actual reported figures by the sample households

2 Almost all households in the katchi abadis were either not connected to the network or were connected illegally so they did not respond to this question

Source: Fieldwork, January 1999

Ninety two percent of the respondents were using the water for multi purposes including drinking, cooking, bathing, and washing. Four percent were not using it for drinking but were buying filtered drinking water and another four percent were using it only for drinking and cooking.

None of the households reported selling water from their piped connection to their neighbors. All in all, almost $75 \%$ of the respondents were either not satisfied at all or less than satisfied with their water service delivery through household piped connection from KWSB. 


$\begin{array}{llllllllllll}\mathrm{C} & \mathrm{H} & \mathrm{A} & \mathrm{P} & \mathrm{T} & \mathrm{E} & \mathrm{R} & \mathrm{T} & \mathrm{H} & \mathrm{R} & \mathrm{E} & \mathrm{E}\end{array}$

EXISTING WATER SUPPLY SITUATION IN KARACHI

\subsubsection{KWSB's Hydrant Supply through Tanker Trucks}

On its creation, in 1983, KWSB installed 14 hydrants in Karachi in response to the unplanned expansion of the previous decade, during which a proportional increase in the bulk supply system was not made. The hydrants were installed to meet the water requirements of areas known as the 'deficient pockets', which were located either at the tail ends of water supply system or on higher geographical ground. Purified water from the treatment plants supplies the hydrants. KWSB used the hydrants to provide water tankers service to its consumers, located in the deficient pockets, and to meet the needs of amenities (i.e. hospitals), and to cope with emergencies encountered as a result of disruption of water supply due to damage in the main trunk or electric failures. The number of water tankers supplied per day was about 4080 in 1983 (KWSB, 1999).

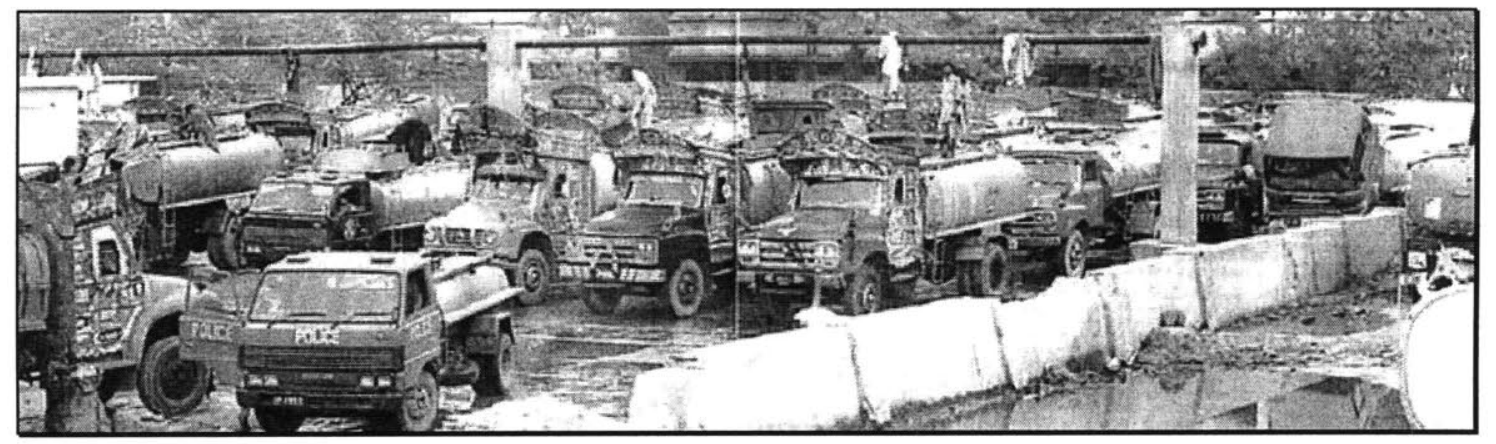

KWSB had initially planned to phase out the water tanker supply and close down many of its hydrants after receiving 100 MGD water from the Indus as a result of the K-2 project. ${ }^{36}$ However, due to dry spell of monsoon for the last couple of years, in the catchment areas of Hub Dam, the desired result of increase of 100MGD has not been achieved. Thus, the curtailment of water supply via water tankers could not be implemented. KWSB has nevertheless decreased the frequency of trips to 450 per day on a commercial basis and 555 per day for its residential consumers. KWSB has also made a serious effort to curtail its hydrant operation and has closed down 8 of its hydrants. At present, only 6 hydrants are operational and only one is used for commercial filling. ${ }^{37}$

\footnotetext{
${ }^{36}$ K-2 Project (Second Karachi Water Supply Project), whereby the city of Karachi will get an additional 100 MGD of water from the Indus source. It is suppose to come into effect by June 15, 1998. (quoted in DAWN - June 5, 1998) ${ }^{37}$ Muslimabad, Jammia Millia, Shah Faisal No. 4, Sakhi Hasan, Frere Town and LSR hydrant all supply water to tanker trucks through contractual arrangement but only at the Muslimabad hydrant is commercial selling allowed.
} 


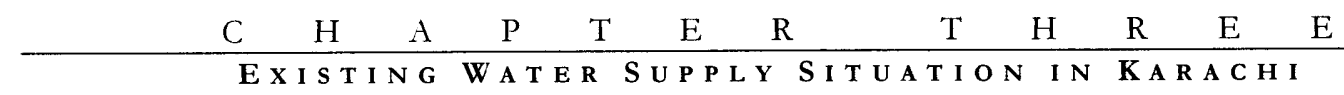

Water supply delivery using hydrants has two components. One is the contractual component, whereby bids are invited each year from tanker truck owners for delivery to households in deficient areas, high seated government officials, and delegates of consulates and embassies. Provision in the KWSB budget for this form of delivery service has been made since 1983-84, when PKR. 4.719 million were allocated for this purpose. This budget grew to PKR. 40 million in 1990-91. For 1997-98 the budget is PKR 30 million. ${ }^{38}$ At present, 11 government contractors, making around 1020 trips per day, have a monopoly over this component of KWSB distribution. Furthermore, according to KWSB documents, most of these trips (almost 80\%) are for katchi abadis and low-income areas to supplement their already existent water supply through standposts. It is estimated that tankered water accounts for around $10 \%$ of the water supplied in Karachi. ${ }^{39}$

Sixty-five percent of households that responding to the survey indicated that they needed KWSB tankers either because their area was not connected to the network or because they were not getting any water through the network system. Overall, the households that responded are either less than satisfied or not satisfied at all with the service, likely because of the time required to get the tanker approved from a local councilor and numerous trips to the hydrant to get a tanker supplied to the household. Sometimes, the tanker truck supply from the government hydrant comes at odd hours of night, making it inconvenient for households. The households that responded to the survey indicated that the tanker from KWSB is not free of cost, as it should be, but rather on an average cost of PKR. 40 for a 1200-gallon tanker truck; the money, which is given as a token to the driver for obliging. ${ }^{40}$

The other component of tanker truck water supply entails commercial selling from the government hydrant, whereby any tanker can be registered as a petty contractor with KWSB by depositing a lump sum in bank as security. ${ }^{41}$ This lump sum is equal to the average number of trips the tanker truck can make in a month multiplied by the filling cost

\footnotetext{
${ }^{38}$ KWSB - 5 year strategic performance 1994-99

39 PSP in KWSB - Strategy Report, 1997

40 One respondent indicated that he/she had to pay PKR. 20 to the councilor for a slip to get a tanker approved, and then pay PKR. 60 to the driver (PKR 30 for the cost of water and PKR. 30 as tip to the driver).

+1 No listing was available of the names or the number of these contractors with KWSB.
} 
for the tanker truck, and it can range from PKR. 5,000 to 10,000. Approximately 450 trips are authorized per day on a commercial basis from KWSB's hydrant, which entails revenue of PKR. 18,900 (\$360.7) per day for the sale of $0.8 \mathrm{MG}$ of water. The filling of water at the hydrant costs PKR. 28 for a 1200 gallon tanker truck and PKR. 56 for a 2400 gallon tanker truck. However, this tanker can be sold in the market from anywhere between PKR. 175 215 or more for a 1200 -gallon tanker and PKR. 365 - 432 or more for a 2400 -gallon tanker. The consumers are mostly located in residential areas, although one tanker truck driver at the government hydrant indicated that the beverage industry in the city is also a big consumer of water from this source.

The tanker truck delivery system is open to exploitation in both the contractual and commercial facets of delivery for various reasons. In Karachi, the contractual vendors (tanker trucks) supply water from the water utility's hydrant source on a regular basis to these deficient areas. The tanker owners are supposed to be paid PKR. $80^{42}$ by KWSB for each trip under the contracted arrangement. Water vendors skip this procedure and charge water consumers PKR. 250 instead, all of which presumably goes into their own pockets. No receipts are given for the consumer payments. The KWSB, according to it's 1997-98 annual report, set aside PKR. 25 million for the contracted payments. If KWSB's procedure is followed, approximately 372,300 tanker trips could be made in one year within the city for water distribution. ${ }^{43}$ Because of the formal arrangement that the vendors have with the utility, they have access to water supply hydrants from which they can get water. Moreover, they are able to sell this tanker truck of water at a higher price, not only to the residents of the "deficient area", but to the residents throughout the city. This is due to the citywide water supply shortage. Clearly, the formal arrangement is giving way to a growing informal tanker truck vending activity. Furthermore, the way the slip transaction is managed at the hydrant, there is only one person collecting and authorizing the slips and checking that the tankers are filled. It is impractical for one individual to monitor these three tasks simultaneously. This has resulted in considerable under the table dealing (corruption) and theft of water from hydrants. ${ }^{44}$

42 This varies depending on the distance from the hydrant to the area serviced.

${ }^{43}$ DAWN Newspaper - 05/20/96

4. This situation is improving, however, because of Governor rule in the Karachi, which has posted army personnel at all the government hydrants. 


$\begin{array}{llllllllllll}\mathrm{C} & \mathrm{H} & \mathrm{A} & \mathrm{P} & \mathrm{T} & \mathrm{E} & \mathrm{R} & \mathrm{T} & \mathrm{H} & \mathrm{R} & \mathrm{E} & \mathrm{E}\end{array}$

EXISTING WATER SUPPLY SITUATION IN KARACHI

\subsubsection{Standpipes}

The total number of standpipes and community taps provided and maintained by KWSB in Karachi is around 3378, most of which are in low-income, water deficient pockets. ${ }^{45} \mathrm{KWSB}$ 's future plans do not indicate improving or expanding the existing system of standpipes in the city.

\subsection{Different Forms of Water Supply - INFORMAL}

The household survey suggests the existence of a thriving informal water delivery service, which takes the form of tanker trucks, private and public wells, neighbors, donkey carts, and neighborhood kiosks that serve households within different income groups in Karachi. ${ }^{46}$ This system coexists with the conventional piped network system discussed above. Between forty-nine and sixty-eight percent, depending on the season, of households with a household connection use a secondary informal water supply source. 85 percent of the households that responded have water connections and only 8 percent do not buy or obtain water from a source other than their household connection. Fifty-five percent of the households buy or obtain water from a single source, 30 percent use two sources, and 5 percent use three or more sources to meet their daily water needs.

\subsubsection{Tanker Truck Vending ${ }^{47}$}

The most common method of informal water supply delivery observed takes the form of a tanker truck that delivers water in bulk quantity to homes from one of the private hydrants in the city. The private hydrants extract ground water from deep-bored wells, and the extracted water is not of potable quality. The truck suppliers can be classified as Primary $\underline{\text { Vendots }}^{48}$ because of the sizeable quantity of water they deliver throughout the city. The

\footnotetext{
${ }^{45}$ Since it is beyond the scope of this thesis, not much documentation on this aspect has been covered. Documentation collected from KWSB does not have any information about community taps.

Also the area selected for survey did not have community taps. The areas where community taps are provided include Baldia, Mauripur Village, Kharadar, Lyari, Nayabad, and Doriabad.

${ }_{46}$ There maybe other forms of water delivery service to households available, which have not been identified, maybe because in the selected areas these were the most prevalent forms of water delivery observed.

${ }^{47}$ This section is covered in more detail in the following chapter

${ }^{48}$ Refer to Chapter 2 for definition, and to Chapter 4 for a more elaborate explanation
} 


$\begin{array}{llllllllllll}C & H & A & P & T & E & R & T & H & R & E & E\end{array}$

clientele for this kind of water supply service is determined by two factors: households with access to lanes wide enough for the tanker trucks to drive in; and households with sufficient capacity to store water in form of an underground water storage tank. Tankers are available in numerous sizes - 1200, 2400, 3600 and 4800 gallons. The 1200 gallons tanker trucks have a larger consumer market in katchi abadis (low-income areas), where people with small plots have limited capacity for underground storage.

The average per trip cost of a water tanker that delivers 1200 gallons to households ranges from PKR. 208 to 270 . This figure fluctuates seasonally, and is higher during the summer months when water demand is high. ${ }^{49}$ In the household survey, 93 percent of those that responded said that houses in their neighborhood buy water from tanker trucks. This response was constant over income groups. However, only 75 percent of the households that responded actually buy water from tanker trucks. Households in the higher income groups buy water from tanker trucks primarily due to water shortage and unreliable service. In the katchi abadis, however, households buy water primarily because they are not connected to the piped network system..$^{50}$ According to survey responses, households seem to be aware of two predominant water supply sources - the commercial KWSB hydrant, and private wells. Forty eight percent of the surveyed households said that the water tankers get water from both these sources, whereas 27 percent indicated that water tankers get the water they sell from the KWSB hydrants. Another 24 percent of households said the water was from private wells. Although it is difficult to distinguish among tanker truck water sources, households that have been buying water for a long time are likely able to make the distinction. The water from KWSB hydrants tends to be sweet water - metha paani, as it is commonly called. Water from the private wells is slightly salty - khara. To a lay man these distinctions are not very apparent

Water bought from tanker trucks is sometimes resold at neighborhood level through kiosks, households, or donkey carts. The resellers can be classified as Secondary Vendors.

\footnotetext{
49 This estimate assumes five months of summer season from April-August.

${ }^{50} 65 \%$ of the household who responded said that they were buying water because of shortage, $16 \%$ said they were not connected to the network (mostly in katchi abadis) and $19 \%$ gave multiple reason as being both shortage of water and unreliable service.
} 


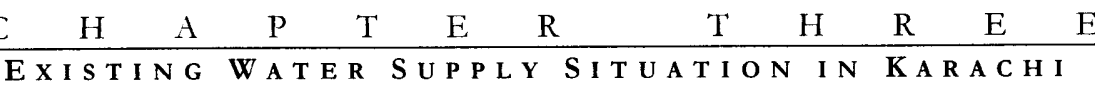

\subsubsection{Public and Private Wells}

Public and private wells are also prevalent water sources for individual households or at neighborhood level as seen from the household survey. Eighteen percent of the respondents use private wells, of which 57 percent are shared. Five percent use public wells, 75 percent of which are individually owned. No private well-owners sell water, and none of the households using public wells buy water from this source with the exception of one household. Households commonly use electric pumps to retrieve water from wells, but hand pumps and buckets are also used in a couple of instances.

According to KWSB sources, a number of consumers in various neighborhoods have constructed shallow bore wells due to low water pressure, and have found water at depths of 20-30 feet. This water, which is brackish, originates from leakage in the water supply and sewerage network and is used primarily for household chores. Seventy-seven percent of households that responded indicated that they use water from public and private wells for bathing and washing. Ninety-two percent of the households using this source of water said that the water tastes salty, while all responded that that water looked clean and clear. On average, however, households thought that the water is risky for general health purposes. Moreover, 89 percent of public and private well-water users indicated that the water constitutes a very small proportion of their daily consumption. About 55 percent of households indicated there is no regular pattern for getting water from the wells, even though 44 percent of the respondents said that water from this source is used daily. Households spend close to fifteen minutes getting water from the wells. Private well owners in the respondent sample indicated that the construction of wells entails an average initial capital investment of almost PKR. 25,000 (\$477.0).

\subsubsection{Donkeys Carts}

Water is also conveniently delivered to household doorsteps via donkey carts that carry water in tanks with an average storage capacity of around 60-100 gallons per trip. This form of vending entails a capital cost of PKR. 15,000-20,000 (\$286.3-381.7), which includes the donkey, the cart, and the water tank. The donkey cart business is typically a one-man 


$\begin{array}{llllllllllllll}\mathrm{C} & \mathrm{H} & \mathrm{A} & \mathrm{P} & \mathrm{T} & \mathrm{E} & \mathrm{R} & \mathrm{T} & \mathrm{H} & \mathrm{R} & \mathrm{E} & \mathrm{E}\end{array}$

EXISTING WATER SUPPLY SITUATION IN KARACHI

show. An individual collects water from a point source of leakage, an underground water storage tank filled by a tanker truck, or from a household connection, and makes around 5-6 trips per day. Donkey cart vendors use cans to transport water from the tank to the households' water storage. The clientele comprises mainly those households with limited water storage facilities or those not easily accessible by motor traffic. The donkey-cart clientele is not entirely fixed; the vendors may get occasional customers from commercial areas, or they may be called to a household while they are riding around the neighborhood. Thus, the number of trips vendors make per day depends on the number of customers they get. The donkey cart vendors can be classified as Secondary Vendors in the supply chain, as primary vendors (tanker trucks, in this case) supply water to them. ${ }^{51}$

The donkey cart vendors live in the neighborhood they cater to. The cost of water delivered on a donkey cart is dependent on the distance of the household from the source of water. The cost of transporting a donkey cartful up to a distance of $2 \mathrm{~km}$ can cost PKR 40, while the same quantity transported over a $3 \mathrm{~km}$ distance can cost PKR. 80. A donkey cart tank can store up to 20 to 26 cans $^{52}$ of water, depending on its size; thus, a canister of water could cost anywhere between PKR. 2 to PKR. 4.

In response to the household survey, 25 percent of respondents identified this source of water delivery as available in their neighborhood. However, only 50 percent of these households actually use this service. The response received was mostly from katchi abadis. According to households interviewed, the donkey carts obtain water from a private well, tanker truck, water connection, or leakage point. The average cost of water reported by households was PKR. 60 for approximately 116 gallons. This figure implies that, on average, a gallon of water from donkey carts costs PKR. 0.52. Almost 60 percent of the households that responded said donkey cart water tastes sweet, while the rest claimed that it is salty. Ninety percent of the households that responded reported that the water looks clean and clear, while 50 percent thought that the water is a risk to public health; 20 percent were neutral, and the rest thought it was safe. Households obtaining water from the donkey carts

${ }^{51}$ Most of this information is based on my field notes observation in summer 1998.

$521 \mathrm{Can}=15 \mathrm{Litres}$ and $1 \mathrm{Litre}=4.5 \mathrm{Gallons}$ 


$\begin{array}{llllllllllll}\mathrm{C} & \mathrm{H} & \mathrm{A} & \mathrm{P} & \mathrm{T} & \mathrm{E} & \mathrm{R} & \mathrm{T} & \mathrm{H} & \mathrm{R} & \mathrm{E} & \mathrm{E}\end{array}$

EXISTING WATER SUPPLY SITUATION IN KARACHI

spend about a quarter of an hour each day performing this function. Sixty percent of the households using donkey-cart vendors get water once a fortnight, while the rest get some every other day. On average, the vendors fulfill 40 percent of the needs of households utilizing donkey cart vendors. Also, households get twice as much water from this source during summer as compared to winters. All in all, the households that use this source are less than satisfied about water quality availability.

\subsubsection{Neighbors}

Neighbor vending may occur when one household within a group of houses is closely located to a main street, has storage capacity, and sells water to its neighbors, typically at a very low cost of PKR. 1 - 1.5 per can. ${ }^{53} \mathrm{~A}$ customer fills up his own cans from a pump controlled by the selling household, which pipes water outside the house. The household's children monitor the operation, while the women handle the cash transaction. This kind of vending is common in the katchi abadis, where people sell water to help cover the cost of water tanker delivery to the household. This form of water delivery is also observed in low and middle-income areas; in these areas, water is shared with rather than sold neighbors.

Thirty-three percent of the households that responded to the survey said that households do get water from other neighbors located within an average distance of 20 feet. Almost 70 percent of these households get water from their neighbors. Of these, only 23 percent actually pay their neighbors for this water. The water from this source is collected and distributed mainly through buckets or extension pipes. The average cost reported by the households is PKR1.4 for one bucket, which carries roughly 15 liters. So, a gallon of water from a neighbor costs approximately PKR. 0.42.

Most of the households indicated that there is no regular pattern of getting water from their neighbors; much of this activity takes place during times of acute water shortage, which occurs now and then. The water from neighbors is used mostly for drinking and cooking purposes. According to the respondents, most of the selling neighbors get water

\footnotetext{
$531 \mathrm{Can}=15$ Litres and 1 Litre $=4.5 \mathrm{Gallons}$
} 


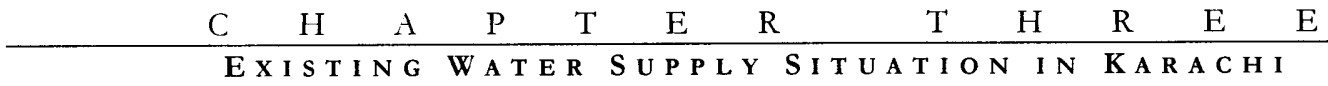

either from private wells or water tankers. The households spend an average of about 45 minutes getting water from the neighbors to their homes. The supply from neighbors constitutes approximately 28 percent of the households' water need. In sum, households are satisfied with this form of water delivery, both in terms of quality and availability of water.

\subsubsection{Kiosks}

Vending from kiosks is a more formal way to sell water at the neighborhood level. The approach is essentially the same as household vending, but a formal shop is set up outside the house. Water from the kiosks is collected and sold by the bucket, which costs PKR. $1.5 .{ }^{54}$ Kiosks are located at the intersection of the main street, targeting the neighborhood level, as people carry water from the kiosks on a shoulder stick, wheelbarrow, bicycle, etc. The water is available from early morning to late night.

Thirteen percent of all households that responded said that their neighbors buy water from kiosks. Sixty percent of these households, mostly katchi abadi residents, get water from kiosks. The unit price of water per gallon from the kiosk is PKR. $0.45\left(\$ 2.3 / \mathrm{m}^{3}\right)$. All households that responded were of the opinion that the kiosk owners get water from the tanker trucks. Households generally conceded that this water is safe from a public health perspective, and most households reported this water to be clean, clear, and sweet in taste. There is no consistent pattern by which households get water from this source. Water from the kiosks meets approximately $18 \%$ of the households' water needs. Households that use this source were somewhat satisfied with this source of service delivery, both in terms of water quality and availability of water.

Other solutions for compensating for water shortage include cost sharing for tanker trucks among renter and owners in one household. Katchi abadis that abut more affluent localities get water in a matk $a^{55}$ from their more fortunate neighbors in the evenings; women are usually seen on the streets carrying these utensils on their heads and knocking on doors for water. Some people who have struck luck boring private wells and find that the ground

\footnotetext{
54 ibid.

${ }^{55}$ Matka - a traditional utensil for carrying of water
} 


\section{$\begin{array}{llllllllllll}\mathrm{C} & \mathrm{H} & \mathrm{A} & \mathrm{P} & \mathrm{T} & \mathrm{E} & \mathrm{R} & \mathrm{T} & \mathrm{H} & \mathrm{R} & \mathrm{E} & \mathrm{E}\end{array}$}

water is of drinkable quality have made it available to their community free of charge as a gesture of good will, but this water only reaches people living close to the source.

\subsection{Sample Household Response to Different Water Sources}

It is apparent from the above discussion that households in Karachi use multiple sources of water. The breakup of the household sample by water source used is illustrated in table 3-9. After household connections, a significant proportion of households uses tanker trucks, both as a primary and secondary source of water for their needs.

\section{Table 3-9: $\quad$ Sample Household's Sources of Water}

\begin{tabular}{|l|c|c|c|c|c|}
\hline SOURCES* & TOTAL & High Income & Middle Income & Low Income & Katchi Abadis \\
\hline KWSB & 34 & 11 & 10 & 10 & 3 \\
& $(85 \%)$ & $(100 \%)$ & $(100 \%)$ & $(100 \%)$ & $(33 \%)$ \\
\hline Private Well & 7 & 0 & 3 & 2 & 2 \\
& $(18 \%)$ & $(0 \%)$ & $(30 \%)$ & $(20 \%)$ & $(22 \%)$ \\
\hline \multirow{2}{*}{ Public Well } & 2 & 0 & 1 & 0 & 1 \\
& $(5 \%)$ & $(0 \%)$ & $(10 \%)$ & $(0 \%)$ & $(11 \%)$ \\
\hline \multirow{2}{*}{ Neighbors } & 9 & 0 & 5 & 2 & 2 \\
& $(23 \%)$ & $(0 \%)$ & $(50 \%)$ & $(20 \%)$ & $(22 \%)$ \\
\hline \multirow{2}{*}{ Donkey Carts } & 5 & 0 & 0 & 5 & 0 \\
& $(13 \%)$ & $(0 \%)$ & $(0 \%)$ & $(50 \%)$ & $(0 \%)$ \\
\hline \multirow{2}{*}{ Kiosks } & 3 & 0 & 0 & 0 & 3 \\
& $(8 \%)$ & $(0 \%)$ & $(0 \%)$ & $(0 \%)$ & $(33 \%)$ \\
\hline \multirow{2}{*}{ Water Tankers } & 29 & 8 & 9 & 6 & 6 \\
& $(73 \%)$ & $(73 \%)$ & $(90 \%)$ & $(60 \%)$ & $(67 \%)$ \\
\hline
\end{tabular}

* Standpipes are not listed, since in the selected areas standpipe distribution is not available; however, it is also another source of water available to households from KWSB

Source: Fieldwork, January 1999

As seen from Table 3-10, 93 percent of the households interviewed obtain or buy water from outside sources; this figure does not include the water connection as one of the sources. The following table classifies the households interviewed on the basis of the number of sources they were using to get water. Eighty-three percent of the households interviewed obtain water from two or more sources. 


$\begin{array}{lllllllllllll}\mathrm{C} & \mathrm{H} & \mathrm{A} & \mathrm{P} & \mathrm{T} & \mathrm{E} & \mathrm{R} & \mathrm{T} & \mathrm{H} & \mathrm{R} & \mathrm{E} & \mathrm{E}\end{array}$

EXISTING WATER SUPPLY SITUATION I N KARACH I

Table 3-10: Sample Household's Number of Water Sources

\begin{tabular}{|c|c|c|c|c|c|}
\hline & Full Sample & High Income & Middle Income & Low Income & Katchi Abadis \\
\hline $\begin{array}{l}\text { Households obtain/buy } \\
\text { water from outside sources }\end{array}$ & $\begin{array}{c}37 \\
(93 \%)\end{array}$ & $\begin{array}{c}9 \\
(82 \%)\end{array}$ & $\begin{array}{c}10 \\
(100 \%)\end{array}$ & $\begin{array}{c}9 \\
(90 \%)\end{array}$ & $\begin{array}{c}9 \\
(100 \%)\end{array}$ \\
\hline $\begin{array}{l}\text { Obtain water from only } \\
\text { one source* }\end{array}$ & $\begin{array}{c}7 \\
(18 \%)\end{array}$ & $\begin{array}{c}3 \\
(27 \%) \\
\end{array}$ & $\begin{array}{c}0 \\
(0 \%) \\
\end{array}$ & $\begin{array}{c}0 \\
(0 \%)\end{array}$ & $\begin{array}{c}4 \\
(44 \%) \\
\end{array}$ \\
\hline $\begin{array}{l}\text { Obtain water from two } \\
\text { sources }\end{array}$ & $\begin{array}{c}19 \\
(48 \%)\end{array}$ & $\begin{array}{c}8 \\
(73 \%)\end{array}$ & $\begin{array}{c}5 \\
(50 \%) \\
\end{array}$ & $\begin{array}{c}4 \\
(40 \%) \\
\end{array}$ & $\begin{array}{c}2 \\
(22 \%) \\
\end{array}$ \\
\hline $\begin{array}{l}\text { Obtain water from three or } \\
\text { more sources }\end{array}$ & $\begin{array}{c}14 \\
(35 \%)\end{array}$ & $\begin{array}{c}0 \\
(0 \%)\end{array}$ & $\begin{array}{c}5 \\
(50 \%)\end{array}$ & $\begin{array}{c}6 \\
(60 \%)\end{array}$ & $\begin{array}{c}3 \\
(33 \%)\end{array}$ \\
\hline
\end{tabular}

* Single source does not necessarily imply only piped water connection

Source: Fieldwork, January 1999

The unit price of water from the different sources is tabulated in Table 3-11. These tabulations are based on the responses received from the household surveys. Per gallon price of water is lowest for the tanker truck and highest for the donkey cart vendor. Average household usage of water from each of these sources is listed in the next column. On average, 58 percent of the water that households are using for drinking, cooking, bathing, washing and other chores comes from tanker trucks and 67 percent from their water connection.

Table 3-11: Unit Cost of Water from Different Source

\begin{tabular}{|l|c|c|}
\hline \multicolumn{1}{|c|}{ Sources of Water } & Price PKR/gallon & $\begin{array}{c}\text { Average percentage need of } \\
\text { each household being fulfilled } \\
\text { from each source }\end{array}$ \\
\hline KWSB & $0.044^{56}\left(\$ 0.22 / \mathrm{m}^{3}\right)$ & $67.2 \%$ \\
\hline Tanker truck & $0.16\left(\$ 0.81 / \mathrm{m}^{3}\right)$ & $58.0 \%$ \\
\hline Donkey carts & $0.52\left(\$ 2.6 / \mathrm{m}^{3}\right)$ & $31.2 \%$ \\
\hline Neighbors & $0-0.42\left(\$ 0-2.1 / \mathrm{m}^{3}\right)$ & $28.1 \%$ \\
\hline Kiosks & $0.45(\$ 2.26)$ & $17.5 \%$ \\
\hline Private wells & 0 & $32.9 \%$ \\
\hline Public wells & 0 & $25.0 \%$ \\
\hline
\end{tabular}

Source: Fieldwork, January 1999

The above table shows that the vended water from the primary vendors (tanker truck) costs almost 4 times as much as water from a piped connection. The price charged by secondary vendors is much higher, but they cater to a particular segment of the society that ${ }^{56}$ Calculated on the basis of bulk supply of PKR. $44 / 1000$ gallons, equals to $\$ 0.22 / \mathrm{m}^{3}$, already explained earlier in the
tariff section 


$\begin{array}{llllllllllll}C & H & A & P & T & E & R & T & H & R & E & E\end{array}$

EXISTING WATER SUPPLY SITUATION IN KARACHI

does not have the storage capacity for water or whose households are not located such that they have access to a main street.

\subsubsection{Satisfaction with existing water services}

Each respondent in the household survey was asked to discuss the different sources used by his or her household, as well as the quality and reliability of each source.

Subsequently, respondents were asked to rate their overall satisfaction with the existing water sources. The result from this survey question has been summarized in table 3-12. Overall, 55 percent of the households that responded to the question were "satisfied" or "very satisfied" with their different water sources and situations. Seventy-two percent of the households, though, were either "less than satisfied" or "not satisfied" with their household connection from KWSB. In contrast, 61 percent of the households were "satisfied" or "very satisfied" with quality and reliability of tanker truck water delivery.

Table 3-12: Level of satisfaction with existing water services

\begin{tabular}{|l|c|c|c|c|c|c|c|c|}
\hline & Overall & KWSB & $\begin{array}{c}\text { Private } \\
\text { Wells }\end{array}$ & $\begin{array}{c}\text { Public } \\
\text { Wells }\end{array}$ & Neighbors & Kiosks & $\begin{array}{c}\text { Donkey } \\
\text { Carts }\end{array}$ & $\begin{array}{c}\text { Water } \\
\text { Tankers }\end{array}$ \\
\hline "Very Satisfied" - & $\begin{array}{c}22 \\
\text { "Satisfied" }\end{array}$ & $\begin{array}{c}9 \\
(55 \%)\end{array}$ & $\begin{array}{c}2 \\
(28.1 \%)\end{array}$ & $\begin{array}{c}2 \\
(50 \%)\end{array}$ & $\begin{array}{c}6 \\
(100 \%)\end{array}$ & $\begin{array}{c}3 \\
(86 \%)\end{array}$ & $\begin{array}{c}1 \\
(100 \%)\end{array}$ & $\begin{array}{c}(20 \%) \\
(61 \%)\end{array}$ \\
\hline "Less than satisfied"- & 18 & 23 & 2 & 0 & 1 & 0 & 5 & 11 \\
$(72 \%)$ & $(50 \%)$ & $(0 \%)$ & $(14 \%)$ & $(0 \%)$ & $(80 \%)$ & $(39 \%)$ \\
\hline
\end{tabular}

Source: Fieldwork, January 1999

\subsubsection{Perception of service from different sources}

The survey asked households to rate the quality each source of water they were using in terms of risks to human health. Households were asked to respond on a scale of 1 to 5 , with 1 being "very safe" and 5 being "very risky". The responses are illustrated in the table below. Forty percent of the households thought that the water from KWSB was "fairly safe"; another 40 percent thought that the water was "risky." In contrast, in response to similar questions about water from the tanker trucks, 38 percent of the respondents thought that the water was "risky", 31 percent said it was fairly safe, and 28 percent were "neutral" in their opinion. 


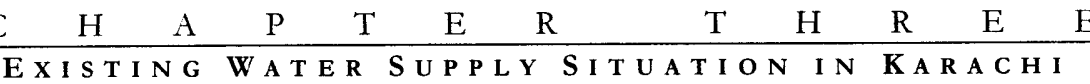

Table 3-13: Perception of public health risk posed by water from different sources

\begin{tabular}{|l|c|c|c|c|c|c|c|}
\hline & KWSB & $\begin{array}{c}\text { Private } \\
\text { Wells }\end{array}$ & $\begin{array}{c}\text { Public } \\
\text { Wells }\end{array}$ & Neighbors & Kiosks & $\begin{array}{c}\text { Donkey } \\
\text { Carts }\end{array}$ & $\begin{array}{c}\text { Water } \\
\text { Tankers }\end{array}$ \\
\hline 1="Very Safe" & $\begin{array}{c}1 \\
(3 \%)\end{array}$ & $\begin{array}{c}1 \\
(14 \%)\end{array}$ & $\begin{array}{c}0 \\
(0 \%)\end{array}$ & $\begin{array}{c}0 \\
(0 \%)\end{array}$ & $\begin{array}{c}0 \\
(0 \%)\end{array}$ & $\begin{array}{c}0 \\
(0 \%)\end{array}$ & $\begin{array}{c}0 \%) \\
(0 \%)\end{array}$ \\
\hline 2=Fairly Safe" & 12 & 2 & 0 & 8 & 4 & 3 & 10 \\
$(30 \%)$ & $(28 \%)$ & $(0 \%)$ & $(18 \%)$ & $(80 \%)$ & $(30 \%)$ & $(31 \%)$ \\
\hline 3="Neutral" & 5 & 0 & 0 & 0 & 0 & 2 & 9 \\
& $(17 \%)$ & $(0 \%)$ & $(0 \%)$ & $(0 \%)$ & $(0 \%)$ & $(20 \%)$ & $(28 \%)$ \\
\hline 4="Risky" & 12 & 2 & 4 & 2 & 1 & 5 & 12 \\
& $(40 \%)$ & $(28 \%)$ & $(100 \%)$ & $(20 \%)$ & $(20 \%)$ & $(50 \%)$ & $(38 \%)$ \\
\hline 5="Very Risky" & 0 & 2 & 0 & 0 & 0 & 0 & 1 \\
\hline & $(0 \%)$ & $(28 \%)$ & $(0 \%)$ & $(0 \%)$ & $(0 \%)$ & $(0 \%)$ & $(3 \%)$ \\
\hline
\end{tabular}

Source: Fieldwork, January 1999

The implication of the households' perception of the potential health risk from different sources of water is reflected in their response to questions about water boiling practices as seen in Table 3-11. Sixty percent of the households "always" boil their drinking water, whereas 33 percent "never" boil their water. Another 7 percent boil their drinking water "half the time" or "less than half the time". The households that never boil their drinking water are mostly from low-income groups and katchi abadi.

Table 3-14: Water Boiling Practices of Households

\begin{tabular}{|l|c|c|c|c|c|}
\hline & Total & High Income & Middle Income & Low Income & Katchi Abadis \\
\hline "Always" & 24 & 10 & 10 & 4 \\
$(100 \%)$ & $(40 \%)$ & $(0 \%)$ \\
\hline $\begin{array}{l}\text { "Half the time"- "Less } \\
\text { than half the time" }\end{array}$ & $(60 \%)$ & $(91 \%)$ & 0 & 1 & 2 \\
"Never" & $13 \%)$ & $(0 \%)$ & $(0 \%)$ & $(10 \%)$ & $(22 \%)$ \\
\hline & $(33 \%)$ & $(9 \%)$ & $(0 \%)$ & 5 & 7 \\
$(78 \%)$
\end{tabular}

Source: Fieldwork, January 1999

\subsubsection{Sample Households' spending on water for tanker trucks}

The table 3-15 indicates that demand for vended water is more in high income then in the other income groups in Karachi. Households in the high-income category were on average buying 5.4 tanker trucks of water per week and spending approximately PKR. 44,614 (US\$850) annually on vended water. Whereas, households in the low-income category were 


$\begin{array}{llllllllllll}\mathrm{C} & \mathrm{H} & \mathrm{A} & \mathrm{P} & \mathrm{T} & \mathrm{E} & \mathrm{R} & \mathrm{T} & \mathrm{H} & \mathrm{R} & \mathrm{E} & \mathrm{E}\end{array}$

EXISTING WATER SUPPLY SITUATION IN KARACHI

buying on average 0.7 tankers weekly and spending PKR. 6,750 (US\$128.8) annually on vended water. This suggests that the demand for vended water in Karachi is highest in highincome groups and these are households with water connection.

Table 3-15: An assessment of the amount of money spent by household on water tankers bought and on the water bill

\begin{tabular}{|l|c|c|c|c|c|}
\hline & Total & $\begin{array}{c}\text { High } \\
\text { Income }\end{array}$ & $\begin{array}{c}\text { Middle } \\
\text { Income }\end{array}$ & $\begin{array}{c}\text { Low } \\
\text { Income }\end{array}$ & $\begin{array}{c}\text { Katchi } \\
\text { Abadis }\end{array}$ \\
\hline $\begin{array}{l}\text { Average number of tanker per week bought by } \\
\text { households in the sample in winter }\end{array}$ & 1.6 & 4.1 & 1.1 & 0.5 & 0.5 \\
\hline $\begin{array}{l}\text { Median number of tanker per week bought by } \\
\text { households in the sample in winter }\end{array}$ & 0.6 & 3.5 & 1.0 & 0.4 & 0.5 \\
\hline $\begin{array}{l}\text { Average number of tanker per week bought by } \\
\text { households in the sample in summers }\end{array}$ & 2.3 & 5.4 & 2.1 & 0.7 & 0.7 \\
\hline $\begin{array}{l}\text { Median number of tanker per week bought by } \\
\text { households in the sample in summers }\end{array}$ & 1.5 & 5.5 & 1.5 & 0.6 & 0.7 \\
\hline $\begin{array}{l}\text { Average total amount spent on tanker trucks per } \\
\text { year (PKR.) }\end{array}$ & $\begin{array}{c}20,377 \\
(\$ 388.9)\end{array}$ & $\begin{array}{c}44,614 \\
(\$ 851.4)\end{array}$ & $\begin{array}{c}18,929 \\
(\$ 361.2)\end{array}$ & $\begin{array}{c}6,750 \\
(\$ 128.8)\end{array}$ & $\begin{array}{c}7,417 \\
(\$ 141.5)\end{array}$ \\
\hline Average water bill /year (PKR.) & $\begin{array}{c}3,977 \\
(\$ 75.9)\end{array}$ & $\begin{array}{c}11,119 \\
(\$ 212.2)\end{array}$ & $\begin{array}{c}1,358 \\
(\$ 25.9)\end{array}$ & $\begin{array}{c}720 \\
(\$ 13.7)\end{array}$ & $\begin{array}{c}1,966 \\
(\$ 37.5)\end{array}$ \\
\hline Factor difference (tanker trucks/KWSB) & 5.12 & 4.01 & 13.9 & 9.4 & 3.8 \\
\hline
\end{tabular}

Source: Fieldwork, January 1999

\subsection{Water Quality Issue}

According to the World Health Organization (WHO) nearly $80 \%$ of all diseases in developing countries are attributable to the use of unsafe water. Safe water is free from pathogenic (disease-causing) organisms; is not saline; has a low turbidity; does not cause corrosion or encrustation; does not contain chemicals, metals or radioactive substances at levels which can have adverse health effects; and does not posses odor or taste (WHO, 1984).

Table 3-16 shows the result of a water sample analysis from 3 different sources in Karachi. One is a KWSB (C) piped water connection. The second source is a private water hydrant (A) located eastern part of city that includes several deep boring sites (>100 feet). The Third sample is from another private hydrant located in the western part of town that also has boring sites (<100 feet). 


$\begin{array}{lllllllllllll}C & H & A & P & T & E & R & T & H & R & E & E\end{array}$

EXISTING WATER SUPPLY SITUATION IN KARACHI

Table 3-16: Analysis of water from different sources ${ }^{57}$

\begin{tabular}{|l|c|c|c|c|}
\hline & WHO Standard & $\begin{array}{c}\text { Private } \\
\text { Hydrants (A) }\end{array}$ & $\begin{array}{c}\text { Private } \\
\text { Hydrant (B) }\end{array}$ & $\begin{array}{c}\text { KWSB } \\
\text { (C) }\end{array}$ \\
\hline pH Level & $6.5-8.5$ & 7.5 & 8.2 & 7.4 \\
\hline Hardness & $500 \mathrm{mg} /$ liter & 135 & 360 & 128 \\
\hline Alkalinity & & 21 & 35 & 20 \\
\hline Color & 15 true color units & 2 & 2 & 2 \\
\hline Turbidity NTU & $<5$ & 0.8 & 0.4 & 0.5 \\
\hline Iron & $\leq 0.3 \mathrm{mg} / \mathrm{L}$ & Nil & 0.02 & nil \\
\hline Aluminum & $\leq 0.2 \mathrm{mg} / \mathrm{L}$ & Nil & Traces & Nil \\
\hline Nitrates & 45 & Traces & Nil & Traces \\
\hline Fluoride & $0.8-1.0 \mathrm{mg} / \mathrm{L}$ & 0.04 & Nil & 0.04 \\
\hline TDS & $\leq 500$ & 310 & 620 & 285 \\
\hline Bacteria in $100 \mathrm{ml}$ & 0 & 35 & 100 & 10 \\
\hline
\end{tabular}

${ }^{1}$ WHO. 1984. Guidelines for Drinking - Water Quality. Geneva : WHO

Source: Waterman International, Karachi, Pakistan

All of the water quality test results from all three sources fall within the range of WHO standard guidelines with the exception of Bacteria. From a public health perspective, the most important aspect of drinking water is the bacteriological quality. The presence of bacteria in water indicates the degree of fecal pollution. It is clear that the water from each of the sources sampled is unsafe for human consumption, as its bacteriological content exceeds the WHO drinking quality standard.

\footnotetext{
${ }^{57}$ Sample has been collected from three separate sources in the city. The KWSB sample has been collected from a house in the eastern part of Karachi. The hydrant water collected from a hydrant located in the east west part of town and the well sample is from another hydrant in the western part of town. Dr. Muti-ur-Rehman tested the chemical composition in Paragon Laboratory, Karachi, Pakistan.
} 
$\begin{array}{llllllllllll}C & \mathrm{H} & \mathrm{A} & \mathrm{P} & \mathrm{T} & \mathrm{E} & \mathrm{R} & & \mathrm{F} & \mathrm{O} & \mathrm{U} & \mathrm{R}\end{array}$

WATER VENDING IN KARACHI
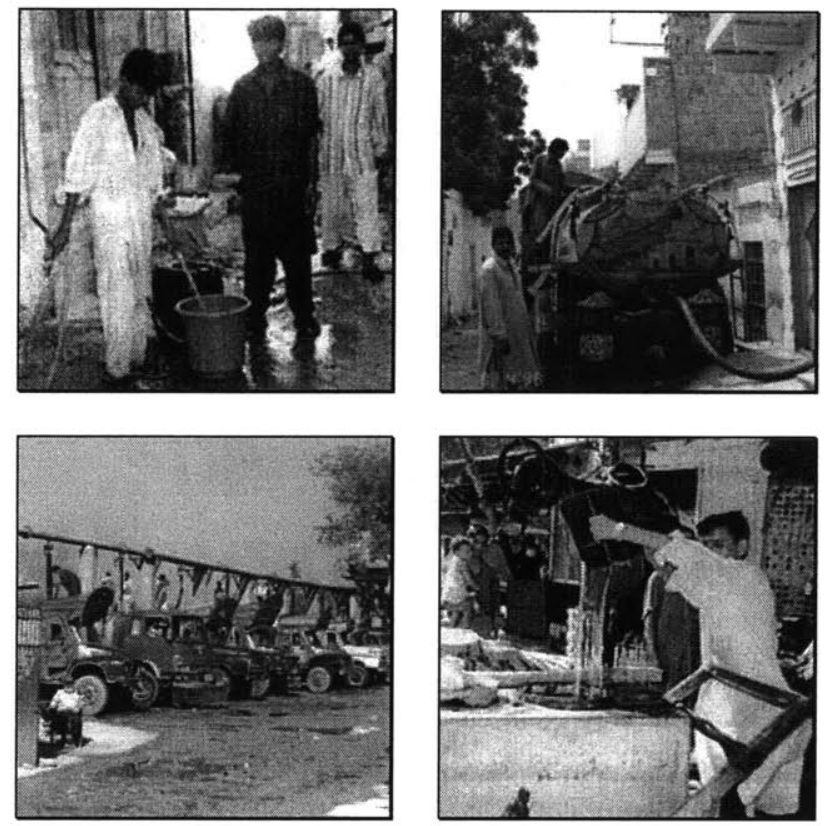


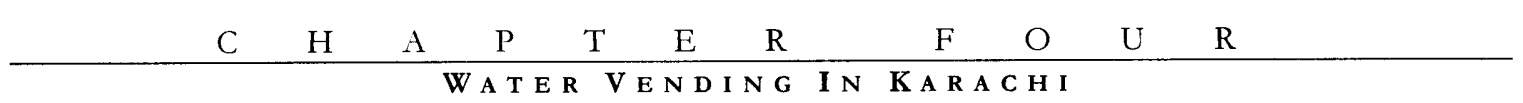

\subsection{Introduction}

Interviews with water vendors, organizations that represent them and personal observations that a thriving and organized water vending industry exists in Karachi. The previous chapter has shown that the clients of the vending industry include households with a wide variety of socioeconomic and water supply characteristics. This chapter now elaborates on the water-vending sector primarily focusing on hydrant owners and tanker truck vendors and regulations that apply to them to analyzed the water distribution in Karachi, and what their market share in water service delivery sector.

The water service delivery from the water vending industry in Karachi can be classified into "providers", those, who are producing and supplying water in the city from ground and surface sources and, "distributors", who are delivering water at household level. The "providers" include the Karachi Water and Sewerage Board (KWSB) and informal, private water suppliers. KWSB provides water to distributing vendors from only one hydrant in the city. Meanwhile, the informal private hydrants are spread throughout the city. The Karachi Metropolitan Corporation (KMC), has documented $106^{58}$ private hydrants in the city (Map 4-1). ${ }^{59}$ The informal private providers are required to be registered with KMC under the "Control and Regulations of Hydrants Bylaws 1994"; ${ }^{60}$ however, currently only 25 private hydrants are registered with KMC. The main distinction between the two providers is their source of water. KWSB supplies treated surface water from its hydrants, whereas the water sold by the private hydrants is untreated groundwater.

Distributors can be further classified into "primary" and "secondary" water vendors. The primary vendors include tanker truck vendors, who obtain water from government or private hydrant, and deliver it to households or industries throughout the city. The primary vendors mostly comprise of tanker trucks, which operate throughout the city. The secondary vendors distribute the water they get from the primary vendors through a leakage point in the main pipe or through their own household connections. Therefore, the quantity of water

\footnotetext{
${ }^{58}$ According to the president of the "Karachi Water Tanker Owners Welfare Association" the number of private hydrants is approximately 200 .

59 More information on the location of these private hydrants is provided in Appendix VI.

${ }^{60}$ Sec Appendix VIII
} 


\begin{tabular}{lllllllllllll}
$C$ & $H$ & $A$ & P & T & E & R & F & O & U & R \\
\hline W A T E R & V E E N D I N G & I N & K A R A C H I & &
\end{tabular}

they distribute is much smaller as compared to the primary vendors. The secondary vendors, however, operate mostly at neighborhood level and comprise of donkey carts, neighbors, kiosks, push carts and bhistee (manual water carrier). ${ }^{61}$ The major distinction between the primary and secondary vendors is the quantity of water they distribute on a daily basis, the scale of operation (city versus neighborhood) and the mode of distribution (vehicle versus animal or foot driven) (figure 4-1).

Figure 4-1: Characterization of the vending industry in Karachi

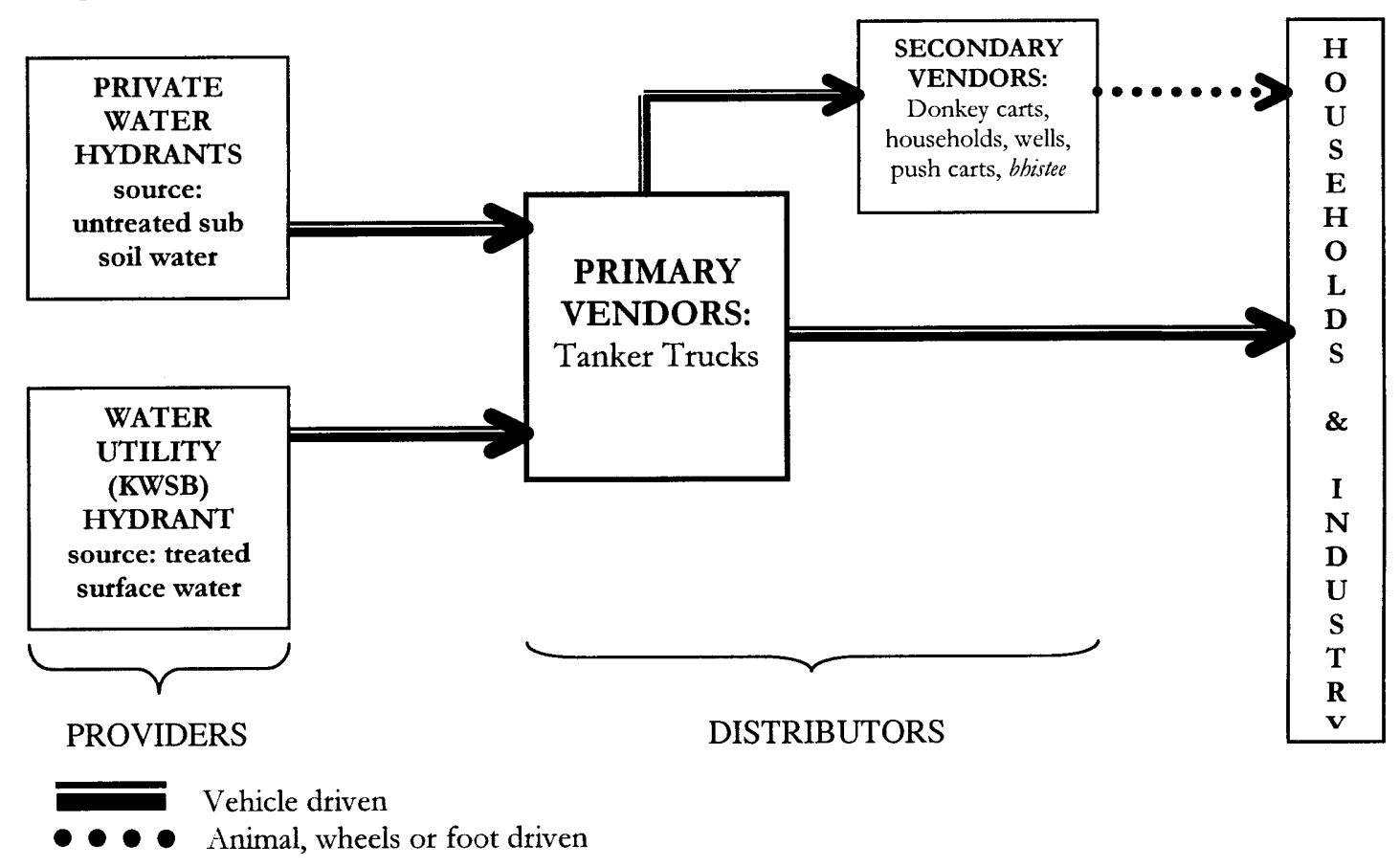

Although it is difficult to estimate how many people are employed in the vending industry in Karachi, according to an estimate the primary vendors, alone, employ approximately 16,000 people, working full time transporting water by tanker trucks from private and government hydrants to all parts of the city. ${ }^{62}$ This estimate, however, does not include the employment of secondary vendors and staff of the city's 106 private hydrants.

61 The different forms of vending observed through the household sample have already been described in Chapter 3 62 This is a direct conclusion from the data collected in the field. There are approximately 4000 tanker truck in Karachi, each tanker truck runs on a double shift and employs two people, the driver and the helper, so in sum only the tanker truck vending generates and provides employment for 16,000 people. 


$\begin{array}{ccccccccccc}\text { C } & \text { H } & \text { A } & \text { P } & \text { T } & \text { E } & \text { R } & \text { F } & \text { O } & \text { U } & \text { R } \\ \text { W A TE R } & \text { VE N D I N G } & \text { I N } & \text { K A R A C H I } & & \end{array}$

\subsection{Primary Distributors: Tanker Truck Vendors and Owners}

The Tanker truck vending industry comprises of two groups, owners and drivers. Owners makes the capital investment for the vehicle and drivers are employees of the owners (or are owners themselves). Almost $50 \%$ of those interviewed were tanker truck owners; of these $71 \%$ were also tanker truck drivers.

Table 4-1: Comparison of socioeconomic and demographic characteristic of water tanker truck owners and drivers

\begin{tabular}{|l|c|c|}
\hline & Tanker Truck Owner $^{\mathbf{1}}$ & Tanker Truck Driver $^{-}$ \\
\hline Average age of vendor (years) & 29.8 & 32.0 \\
\hline Average \# of year working as a vendor & 9.4 & 8.2 \\
\hline Percentage of vendors who migrated from upcountry & $50 \%$ & $87 \%$ \\
\hline \multicolumn{1}{|c|}{ Average length of residence in Karachi (years) } & 12.8 & 14.0 \\
\hline Average earning per month & $\begin{array}{c}\text { PKR. } 42,419 \\
(\$ 809.8)\end{array}$ & $\begin{array}{c}\text { PKR. 3,891 } \\
(\$ 74.3)\end{array}$ \\
\hline Median earning per month & $\begin{array}{c}\text { PKR. 36,000 } \\
(\$ 687.3)\end{array}$ & $\begin{array}{c}\text { PKR. 3,750 } \\
(\$ 71.6)\end{array}$ \\
\hline Percentage reporting affiliation with a vendor association & $69 \%$ & $29 \%$ \\
\hline
\end{tabular}

${ }^{1}$ Seventy one percent of those who responded as owners were also tanker truck drivers

Note: $\quad$ US $\$=P K R .52 .4$ for January, 1999

Source: Fieldwork, January 1999

The typical tanker truck vendor in Karachi is a male aged 30.9 years old who has been working as a vendor for an average of 8.8 years (table 4-1). All vendors reported that tanker truck vending is a full-time job for them. Almost $30 \%$ of the tanker truck vendors interviewed were born in Karachi, whereas, the rest had migrated from upcountry and lived in Karachi for an average of 13.6 years. ${ }^{63}$ The data shows that this profession attracts a high percentage of migrant population from upcountry.

\section{Table 4-2: $\quad$ Tanker truck vendors and their sources of water}

\begin{tabular}{|l|c|}
\hline & Percentage (\%) \\
\hline Percentage of vendors who obtain water from KWSB hydrant only & 58.8 \\
\hline Percentage of vendors who obtain water from private hydrant & 70.6 \\
Percentage of vendors who obtain from both KWSB and private hydrant & 41.2 \\
\hline
\end{tabular}

Source: Fieldwork, January 1999

\footnotetext{
${ }^{63}$ The data shows that $70 \%$ of the time the migrant tanker truck vendor was living in Karachi, he has employed in this profession for at least 8 years.
} 


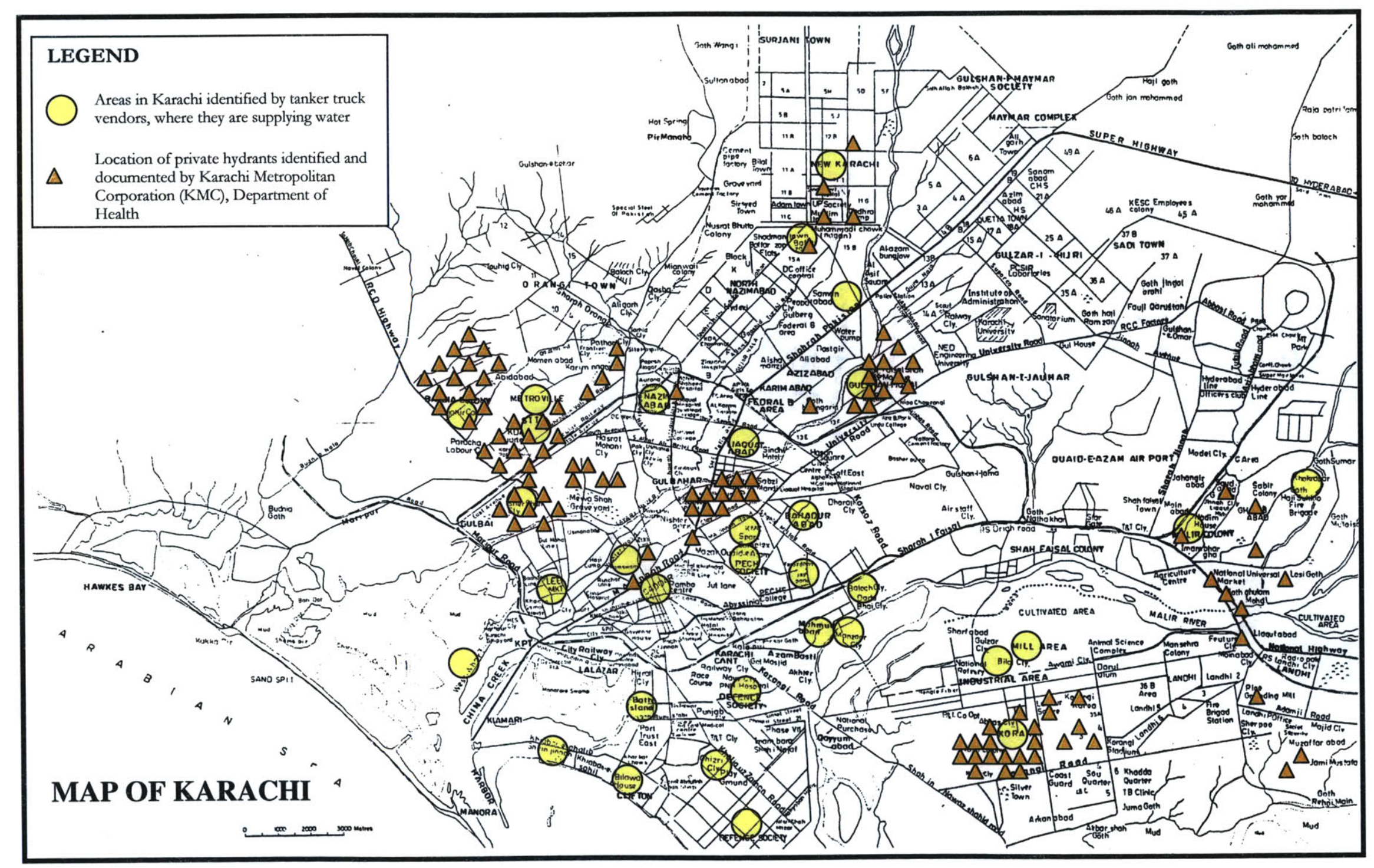

Map 4-1: Location of Private Hydrants and the Areas they are servicing Source: Urban Resource Center, Karachi 


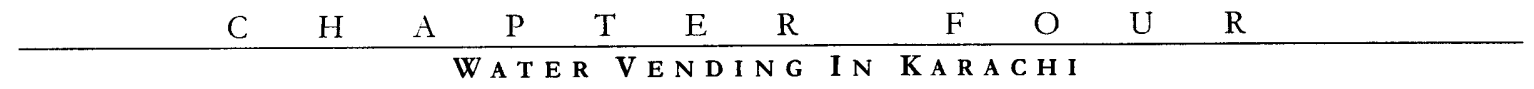

Approximately $59 \%$ of the vendors interviewed indicated that they obtain water from the government hydrant at an average cost of PKR. 28.0 (US\$0.5) for 1200 gallons. Whereas, almost $71 \%$ of the vendors interviewed obtained the same volume of water from the private hydrants at an average cost of PKR. 23.3 (US\$0.4). Not all vendors interviewed were getting water from only one source (government hydrant or private hydrant), $59 \%$ of the vendors who responded were obtained water from the government or private hydrant only, whereas $41 \%$ obtained water from both the government and private hydrants (Table 4-2 \& 4-3). The price structure of water at the government and private hydrant suggests that the price of the water sold at the government hydrant is approximately $17 \%$ to $21 \%$ higher than the private hydrant. This indicates that the private hydrants are setting their price of water in direct competition with the price of water at the government hydrant.

\section{Table 4-3: Cost of water to the vendor at the hydrant}

\begin{tabular}{|l|c|c|}
\hline & 1200 gallons & 2400 gallons \\
\hline Average Price of filling of a tanker truck at govt. hydrant & PKR. 28.0 & PKR. 56.0 \\
\hline Average Price of filling of a tanker truck at pvt. hydrant & $(\$ 0.5)$ & $(\$ 1.1)$ \\
\hline
\end{tabular}

Source: Fieldwork, January 1999

The vendors interviewed were asked to identify the areas of Karachi where they typically deliver water (Map 4-1). It is apparent from the map that vended water is being sold throughout Karachi. ${ }^{64}$

Tanker truck vendors interviewed reported that in peak season on average, they sell 7 trucks of either 1200 or 2400 gallons of water per day. ${ }^{65}$ However, during off-peak season on average their sales are reduced to 5 tanker trucks per day. These findings are supported by reports from household members who purchase vended water (Table 3-15). According to vendors, the water vending business operates on average for 19 hours per day, 7 days a week all year round. ${ }^{66}$

\footnotetext{
${ }^{6+}$ Names of the areas identified by vendors are listed in Appendix VII

${ }^{65}$ Estimate assumes five months of peak season for summers from April to August

${ }^{66}$ Interviews with hydrant owners indicated that the business runs for 24 hours a day
} 


$\begin{array}{ccccccccccc}\text { C } & H & \text { A } & \text { P } & \text { T } & \text { E } & \text { R } & \text { F } & \text { O } & \text { U } & \text { R }\end{array}$

Table 4-4: Overview of the water vending business in Karachi

\begin{tabular}{|l|c|c|c|}
\hline & $\begin{array}{c}\text { Full } \\
\text { Sample }\end{array}$ & $\begin{array}{c}\text { Tanker Truck } \\
\text { Owners }\end{array}$ & $\begin{array}{c}\text { Tanker Truck } \\
\text { Drivers }\end{array}$ \\
\hline Number of vendors surveyed & 34 & 17 & 17 \\
\hline Average number of working days / week & 6.8 & 6.7 & 6.9 \\
\hline Average number of months worked / week & 11.7 & 11.6 & 11.8 \\
\hline Average number of hours worked / day & 13.42 & -2 & 13.42 \\
\hline Average number of hours the business operates each day & 19.27 & 18.75 & 19.76 \\
\hline Average number of tankers ${ }^{3}$ sold per day during peak season ${ }^{4}$ & 7 & 6 & 7 \\
\hline Average number of tankers sold per day during off peak season & 5 & 4 & 5 \\
\hline Percentage of vendors with regular customers & $77 \%$ & $80 \%$ & $73 \%$ \\
\hline ....of these, \% offering & & & $80 \%$ \\
\hline Discounts & $83 \%$ & $85 \%$ & $90 \%$ \\
\hline
\end{tabular}

${ }^{1}$ Seventy one percent of those who responded as owners were also tanker truck drivers

${ }^{2}$ Numbers of trips the tanker truck makes is irrespective of the gallons or volume it can carry

${ }^{3}$ Estimate assumes five months of peak season for summers from April to August

Source: Fieldwork, January 1999

Almost $77 \%$ tanker truck vendors reported having customers to whom they deliver water on a regular basis; of these $83 \%$ indicated that they give these customers a special discount (Figure 4-2). Non-regular customers pay approximately $28 \%$ more than regular customers for a 2400 -gallon tanker truck, and almost $41 \%$ more than the regular customer for a 1200-gallon truck. Furthermore, both regular and non-regular customers were paying on an average $8 \%$ more per tanker truck during peak season as compared to off peak season.

Table 4-5: Price of water for regular and non-regular customers, by season

\begin{tabular}{|l|c|c|}
\hline & 2400 gallons & 1200 gallons \\
\hline Regular customer average price during peak season* & $\begin{array}{c}\text { PKR 299.8 } \\
(\$ 5.7)\end{array}$ & $\begin{array}{c}\text { PKR 140.2 } \\
(\$ 2.7)\end{array}$ \\
\hline Regular customer average price during off peak season & PKR 287.3 & $\begin{array}{c}\text { PKR } 131.0 \\
(\$ 2.5)\end{array}$ \\
\hline Non regular customer average price during peak season* & PKR 395.0 & PKR 199.3 \\
\hline Non regular customer average price during off peak season & PKR 353.9 & $(\$ 7.5)$ \\
\hline
\end{tabular}

*This estimate assumes five months of peak season for summers from April to August

Source: Fieldwork, January 1999

Another privilege afforded to regular customers is credit for payment of their bills. Approximately $96 \%$ of tanker truck vendors indicated that they extend credit to their regular customers, with almost $90 \%$ providing monthly credit. 


$\begin{array}{lllllllllllll}\text { C } & H & \text { A } & \text { P } & \text { T } & \text { E } & \text { R } & \text { F } & \text { O } & \text { U } & \text { R }\end{array}$

Other factors that can affect the final price of the tanker truck to the household include (1) travelling distance from the source of water; (2) ability of households to pay for services; and (3) the length of the pipe required to transfer water from the tanker truck to a household's underground water storage tank.

Tanker truck operators can obtain raw water either from the KWSB hydrant or more than 100 private hydrants throughout the city (Table 4-6). The unit price per gallon at the government hydrant is higher than the private hydrants; however, the average profit per unit gallon from the government hydrant is $7 \%$ less than the private hydrant. However, the selling price of water per gallon from the KWSB's hydrant is approximately $10 \%$ to $13 \%$ higher from the private hydrant.

Table 4-6: Comparison between water service delivery from KWSB and private hydrant

\begin{tabular}{|c|c|c|}
\hline & KWSB Hydrant & Private Hydrant \\
\hline Customer Type & Residential & $\begin{array}{l}\text { Residential and } \\
\text { Industrial }\end{array}$ \\
\hline Approximate shate of total sales supplied to these customer types & $>80 \%$ & $\approx 55 \%$ and $45 \%$ \\
\hline Average \# of tankers sold per day during peak season & 3 & 7 \\
\hline $\begin{array}{l}\text { Average \# of tankers sold per day during off peak season }(1200 \& 2400 \\
\text { gallons) }\end{array}$ & 3 & 5 \\
\hline Average queuing time at water hydrant during peak season (minutes) & 144 & 74 \\
\hline Queuing time at water hydrant during off peak season (minutes) & 92 & 25 \\
\hline Average price of water per gallon at the water hydrant (PKR.) & $\begin{array}{c}0.023 \\
\left(\$ 0.12 / \mathrm{m}^{3}\right) \\
\end{array}$ & $\begin{array}{c}0.020 \\
\left(\$ 0.10 / \mathrm{m}^{3}\right) \\
\end{array}$ \\
\hline $\begin{array}{l}\text { Average price of water per gallon to the (including all costs, diesel, } \\
\text { bhatta(bribes) and maintenance) (PKR.) }\end{array}$ & $\left(\$ 0.45 / \mathrm{m}^{3}\right)$ & $\begin{array}{c}0.070 \\
\left(\$ 0.35 / \mathrm{m}^{3}\right)\end{array}$ \\
\hline Average selling price of water per gallon during peak season (PKR.) & $\begin{array}{c}0.180 \\
\left(\$ 0.90 / \mathrm{m}^{3}\right)\end{array}$ & $\begin{array}{c}0.164 \\
\left(\$ 0.82 / \mathrm{m}^{3}\right)\end{array}$ \\
\hline Average selling price of water per gallon during off peak season (PKR.) & $\begin{array}{c}0.149 \\
\left(\$ 0.75 / \mathrm{m}^{3}\right)\end{array}$ & $\begin{array}{c}0.132 \\
\left(\$ 0.66 / \mathrm{m}^{3}\right) \\
\end{array}$ \\
\hline Average profit on per gallon during peak season (PKR.) & $\begin{array}{c}0.068 \\
\left(\$ 0.34 / \mathrm{m}^{3}\right)\end{array}$ & $\begin{array}{c}0.073 \\
\left(\$ 0.37 / \mathrm{m}^{3}\right) \\
\end{array}$ \\
\hline Average profit on per gallon during off peak season (PKR.) & $\begin{array}{c}0.057 \\
\left(\$ 0.29 / \mathrm{m}^{3}\right) \\
\end{array}$ & $\begin{array}{c}0.061 \\
\left(\$ 0.31 / \mathrm{m}^{3}\right) \\
\end{array}$ \\
\hline
\end{tabular}

Source: Fieldwork, January 1999

Another distinction between the government and the private hydrant is the queuing time to fill the tanker truck. The waiting at the KWSB hydrant the waiting is twice that of a private hydrant, as a result, tanker trucks sold per day from the private hydrant is almost 


\begin{tabular}{cccccccccccc}
$\mathrm{C}$ & $\mathrm{H}$ & $\mathrm{A}$ & $\mathrm{P}$ & $\mathrm{T}$ & $\mathrm{E}$ & $\mathrm{R}$ & $\mathrm{F}$ & $\mathrm{O}$ & $\mathrm{U}$ & $\mathrm{R}$ \\
\hline W A T E R & V E N D I N G & I N & K A R A C H I & &
\end{tabular}

twice as those sold from the KWSB hydrant. This makes the private hydrants a more lucrative option for tanker truck vendors, therefore, it provides better business proposition in terms of number of trip per day and lower cost of water at the hydrant.

Table 4-7 shows the daily revenues and costs of a typical tanker truck owner and driver. The main costs to the tanker truck owner are the vehicle, hired or his own labor, water and the opportunity cost of his capital investment. The average initial investment for a tanker truck, is approximately PKR. 560,719 (US\$10,700). Drivers can be hired for approximately PKR. 5,500 (US\$105) per month. A monthly supply of water costs an average of PKR. 4,620 (US\$88), and miscellaneous expenses (e.g., certificates and permits, insurance, taxes) amount to roughly PKR. 5,400 (US\$103) annually. In sum, entering the water vending business in Karachi requires an initial capital investment of approximately PKR. 600,000 (US\$11, 450). ${ }^{67}$ Working 13 hours per day, 7 days a week the distributing vendors can recover his investment in a little more than three years (assuming average profits of PKR. 16,400 (US\$315) per month). The imputed daily wage rate for the tanker truck owner is PKR. 529 (US\$10) which is almost four times the average wage rate of an unskilled laborer in Karachi. ${ }^{68}$ Distributing water to Karachi households as the owner of a tanker truck is indeed a lucrative business but distributing vendors are not making excessive profits.

A typical tanker truck driver who does not own his own vehicle is male, works for almost 14 hours a day, 7 days per week, and earns PKR. 3,900 (US $\$ 74$ ) per month. This wage is approximately $8 \%$ lower than the average wage tate of an unskilled labor in Karachi. ${ }^{69}$ However, this position entails no investment or commercial risk on the driver's part.

${ }^{67}$ For one tanker truck of either 1200 or 2400 gallons

68 The wage rate of an unskilled laborer in Karachi is approximately PKR 141 (US\$2.7) (as reported by households).

${ }^{69}$ Same as the previous footnote 


$\begin{array}{lllllllllll}\mathrm{C} & \mathrm{H} & \mathrm{A} & \mathrm{P} & \mathrm{T} & \mathrm{E} & \mathrm{R} & \mathrm{F} & \mathrm{O} & \mathrm{U} & \mathrm{R}\end{array}$

Table 4-7: Daily costs and revenue of a typical vendor

\begin{tabular}{|c|c|c|}
\hline & Tanker Truck Owner & Tanker Truck Driver \\
\hline Average Revenue (PKR./day) & $1414(\$ 27.0)$ & $130(\$ 2.5)$ \\
\hline Average estimated costs (PKR./day) & $884.8(\$ 16.9)$ & 0 \\
\hline average cost of tanker truck ${ }^{1}$ & $153.6(\$ 2.9)$ & 0 \\
\hline labor $^{2}$ & $178.3(\$ 3.4)$ & 0 \\
\hline water $^{3}$ & $153.9(\$ 2.9)$ & 0 \\
\hline Fitness certificate for the tanker truck & $4.4(\$ 0.1)$ & 0 \\
\hline Insurance & $0.3(\$ 0.005)$ & 0 \\
\hline road permit & $2.0(\$ 0.04)$ & 0 \\
\hline road tax & $8.2(\$ 0.2)$ & 0 \\
\hline opportunity cost and tisk premium ${ }^{4}$ & $384.1(\$ 7.3)$ & 0 \\
\hline Imputed daily wage rate (tevenue - cost) / shift & $529.2(\$ 10.0)$ & $130(\$ 2 . .5)$ \\
\hline \multicolumn{3}{|c|}{$\begin{array}{l}{ }^{1} \text { Assumes an average cost per truck of PKR. 560,710 (US\$ 10,700) and an annual depreciation rate of } 10 \% \\
2 \text { Two people are employed per tanker truck: one is the driver who earns PKR. } 3750 \text { (US } \$ 72 \text { ), the other employee is a cleaner and earns } \\
\text { approximately PKR. } 1600 \text { (US } \$ 31 \text { ) per month, the cost figure used accounts for both. } \\
{ }^{3} \text { Assumes that tanker trucks makes } 6 \text { trips per day costing PKR. } 25.65 \text { (US\$0.5) (average of PKR. } 23.33 \text { and } 28 \text { from government and } \\
\text { private hydrant) for } 1200 \text { gallons } \\
{ }^{4} \text { Opportunity cost is on the capital investment is taken to be } 15 \% \text { and risk premium is taken as } 10 \% \text {. This calculation is based on bank } \\
\text { borrowing rate prevalent in January } 1999 \text {. }\end{array}$} \\
\hline
\end{tabular}

Source: Fieldwork, January 1999

According to the Water Tanker Owners Welfare Association the price of a tanker truck for 1200 gallons was same in 1992 as it is today, implying that in real terms the value of water has fallen, although the cost of labor and fuel have increased over the same period. This suggests that competition in the vending industry has kept prices from increasing. The association has a membership of approximately 5000 and according to them roughly 4000 tanker trucks operate on a daily basis in Karachi. Almost $63 \%$ of the tanker trucks operating in Karachi have a capacity of 1200 ; the rest have a capacity of 2400 gallons.

It is apparent that water vending by tanker trucks operates as a small-scale competitive industry. Vended water is expensive in Karachi not because vendors are charging monopoly prices but because of high startup cost (initial investment) for the tanker truck owner, can be seen in table 4-7 as opportunity cost and risk premium on investment. 


\begin{tabular}{cccccccccccc}
$C$ & $H$ & $A$ & $P$ & $T$ & $E$ & $R$ & $F$ & $O$ & $U$ & $R$ \\
\hline W A T E R & V E E N D I N G & I N & KA R R A C H I &
\end{tabular}

\subsection{Private Water Hydrants}

The first private hydrant in Karachi was built in 1983; since then the number has grown to $106 .^{70}$ These hydrants invest heavily in extracting untreated groundwater and selling it to tanker truck vendors, who then deliver it throughout the city. Based on the observation in the filed, these hydrants can be classified as large, medium and small sized. This classification is based on several factors (1) the number of water points for filling the tanker trucks, which can range from anywhere between 1 to 12 or more; (2) the plot size on which the hydrant is located; and (3) number of tanker trucks of water sold each day from the hydrant, this number can range from anywhere 60 to 1000 tanker trucks.

Private hydrants are clustered in different parts of the city (Map 4-1). Furthermore, they are usually located close to a drainage channel or a riverbed where groundwater is available. These hydrants do not treat the ground water in any way before selling it tanker trucks. $^{71}$

Based on the number of tanker trucks in Karachi and the average number of trips these tanker truck make each day, approximately 16,000 tanker trips of water are made each day from theses private hydrants. ${ }^{72}$ Approximately 27 MGD (million gallons per day) of water are transported each day from the private hydrants to households and industries in Karachi. ${ }^{73}$ All transaction at the private hydrants is either based on cash or monthly credit.

Although private and KWSB hydrants provide water of different quality and the origin (untreated groundwater versus treated surface water), the two compete against one another for customers. The price per unit volume of water is approximately $20 \%$ lower at the private hydrant, and their growing number and clustered location provide additional pressure to keep prices low.

\footnotetext{
${ }^{70}$ Although, only 106 hydrants have been documented by KMC. However, according to the president, hydrant association, there are approximately 200 private hydrant in the city.

71 The water quality aspect of water from different source has been discussed in Chapter 3

72 According to the Tanker Owners Welfare Association there are 4000 tankers and they each make on an average 4 trips a day (it ranges from 7-4), this calculation assume the lower range.

${ }^{73}$ Assuming the average number of trips to 6 per tanker truck, the quantity of water sold per day from the private hydrants would equal $40 \mathrm{MGD}$.
} 


$\begin{array}{ccccccccccc}\text { C } & H & \text { A } & \text { P } & \text { T } & \text { E } & \text { R } & \text { F } & \text { O } & \text { U } & R \\ \text { W A T E R } & \text { V E E N D I N G } & \text { I N } & \text { K A R A C H I } & \end{array}$

Table 4-8: Daily costs and revenue of a private hydrant owner ${ }^{74}$

\begin{tabular}{|c|c|c|c|c|}
\hline & Average & Median & Min & Max \\
\hline Number of years operating hydrant & 2.5 & 2.1 & 0.25 & 5 \\
\hline Depth of the bore hole (feet) & 130.7 & 125 & 50 & 250 \\
\hline Average number of bore holes & 8.75 & 9 & 5 & 12 \\
\hline Diameter of the bore (inches) & 8 & 6 & 3 & 15 \\
\hline Number of water points for filling & 5 & 4 & 1 & 12 \\
\hline Number of water tankers filling water per day & 398 & 200 & 60 & 1000 \\
\hline Cost of water at the source (PKR.)/1200 gallons & $\begin{array}{c}19.3 \\
(\$ 0.36)\end{array}$ & $\begin{array}{c}20 \\
(\$ 0.38)\end{array}$ & $\begin{array}{c}15 \\
(\$ 0.28)\end{array}$ & $\begin{array}{c}25 \\
(\$ 0.48)\end{array}$ \\
\hline Revenue from sale of water / day (PKR) & $\begin{array}{c}14,361 \\
(\$ 274.1)\end{array}$ & $\begin{array}{c}8,100 \\
(4154.6)\end{array}$ & $\begin{array}{c}1620 \\
(\$ 30.9)\end{array}$ & $\begin{array}{c}36,000 \\
(\$ 687.1)\end{array}$ \\
\hline Number of people employed & 12 & 6 & 2 & 50 \\
\hline Number of hours the business operates & 24 & 24 & 24 & 24 \\
\hline Capital cost for one bore (PKR) & $\begin{array}{c}377,143 \\
(\$ 7,197.4)\end{array}$ & $\begin{array}{c}400,000 \\
(\$ 7,633.6)\end{array}$ & $\begin{array}{c}60,000 \\
(\$ 1,145.1)\end{array}$ & $\begin{array}{c}700,000 \\
(\$ 13,358.8)\end{array}$ \\
\hline O\&M cost / month (PKR.) & $\begin{array}{c}166,667 \\
(\$ 3,180.7)\end{array}$ & $\begin{array}{c}150,000 \\
(\$ 2,862.6)\end{array}$ & $\begin{array}{c}125,000 \\
(\$ 2,385.5)\end{array}$ & $\begin{array}{c}225,000 \\
(\$ 4,293.9) \\
\end{array}$ \\
\hline \multicolumn{5}{|l|}{ Average estimated costs (PKR/day) } \\
\hline capital cost $^{1}$ & $\begin{array}{c}904 \\
(\$ 17.3)\end{array}$ & $\begin{array}{c}986 \\
(\$ 18.8)\end{array}$ & $\begin{array}{c}82 \\
(\$ 1.6)\end{array}$ & $\begin{array}{c}2,301 \\
(\$ 43.9)\end{array}$ \\
\hline $\mathrm{O} \& \mathrm{M}^{2}$ & $\begin{array}{c}5,556 \\
(\$ 106.1)\end{array}$ & $\begin{array}{l}5,000 \\
(\$ 95.4) \\
\end{array}$ & $\begin{array}{l}4,167 \\
(\$ 79.5)\end{array}$ & $\begin{array}{l}7,500 \\
(\$ 143.1)\end{array}$ \\
\hline $\mathrm{KMC} \mathrm{fee}^{3}$ & $?$ & $?$ & $?$ & $?$ \\
\hline land $\operatorname{tax}^{4}$ & $?$ & $?$ & $?$ & $?$ \\
\hline opportunity cost ${ }^{5}$ & $\begin{array}{c}2261 \\
(\$ 43.1)\end{array}$ & $\begin{array}{c}2466 \\
(\$ 47.1)\end{array}$ & $\begin{array}{c}123 \\
(\$ 2.3)\end{array}$ & $\begin{array}{c}5753 \\
(\$ 109.8)\end{array}$ \\
\hline Imputed daily wage rate (revenue-cost) & $\begin{array}{c}5641 \\
(\$ 107.7) \\
\end{array}$ & $\begin{array}{c}-352 \\
(-\$ 6.8) \\
\end{array}$ & $\begin{array}{c}-2,752 \\
(-\$ 52.6) \\
\end{array}$ & $\begin{array}{c}20,445 \\
(\$ 390.2) \\
\end{array}$ \\
\hline
\end{tabular}

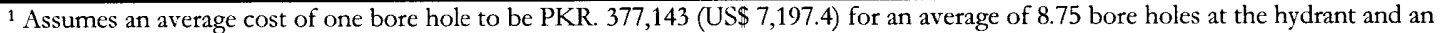
annual depreciation rate of $10 \%$. However, land cost is not included in this calculation.

${ }^{2}$ Assume average $\mathrm{O} \& \mathrm{M}$ per month is 166,667 (US\$3,180), which include the cost per month and includes the cost of labor and electricity

${ }^{3} \mathrm{KMC}$ according to its bye laws charges a fee which is based on the horsepower used to extract water - this information was not asked of the respondent because of its technical and would have been difficult to verify the information

${ }^{4}$ Land on which the hydrant is taxable in Karachi and this amount is accrued annually and is based on the value of the property

${ }^{5}$ Opportunity cost is on the capital investment is taken to be $15 \%$ and risk premium is taken as $10 \%$. This calculation is based on bank

borrowing rate prevalent in January 1999

Source: Fieldwork, January 1999

Table 4-8 shows the daily revenues and costs of a typical private hydrant owner. The main costs to the hydrant owner include capital $\operatorname{cost}^{75}$ which is based on the number of bore holes at the hydrant, operation and maintenance cost and the opportunity cost of the capital investment. The average initial investment for a hydrant owner for one bore hole is PKR. 377,100 (US\$7197). Average operation and maintenance cost is PKR. 166,700 (\$3180) per month. The average in the table 4-8 indicates that operation and maintenance and the

\footnotetext{
74 These calculation are based on limited data collected from the hydrant owner, for this reason the mean, median, min and max are all being reported to provide a complete picture

75 Assumes capital cost to include only the cost of bore holes, land cost is not included
} 


\begin{tabular}{ccccccccccc}
$C$ & $H$ & $A$ & $P$ & $T$ & $E$ & $R$ & $F$ & $O$ & $U$ & $R$ \\
\hline W A T E R & VE N D I N G & I N & K A R A C H I &
\end{tabular}

opportunity cost of investment is very high for the private hydrant owners. However, as seen through the range presented in the table, it can be concluded that the hydrant owners are making more than a fair return each day on their investment as compared to the tanker truck owners (table 4-7 \& 4-8). The imputed daily wage rate for the private hydrant owner is PKR. 5641 (US\$108) which is almost forty times the average wage rate of an unskilled laborer in Karachi. ${ }^{76}$ This suggests the possibility of rent seeking behavior by hydrant owners. $^{77}$

\subsection{Control and Regulations of Hydrants Bylaws 1994}

The bylaws pertaining to the control and regulation of hydrants are applicable both to private hydrant owners and to tanker trucks delivering water from these locations. The Karachi Metropolitan Corporation (KMC) licenses the private hydrants, with the condition to supply water for non-drinking purposes only. ${ }^{78}$ Evidence from this study, however, indicates that the water from these hydrants is also being used for drinking purposes.

Despite the fact that tankers supplying water from private hydrants are required to be painted pink and those supplying potable water are to be painted green. The KMC was directed to monitor the tankers and to take preventive or penal action against violators; however, little enforcement has been implemented.

KMC in 1998 made an effort to document the hydrant that fall under its jurisdiction, as a result of this effort it has documented 106 hydrants in the city. According to KWSB, however, only 25 are registered with KMC and only 3 have been authorized to sell drinking water. These three hydrants lie within a cluster of many and could have been given this clearance due to some political clout of the owners.

\footnotetext{
${ }^{76}$ The wage rate of an unskilled laborer in Karachi is approximately PKR 141 (US\$2.7) (as reported by households). ${ }^{77}$ Implying that individuals act in ways to create and sustain monopolies in the provision of water from which they can derive private gains, and such rent seeking behavior can have far-reaching implications for management of urban water systems (Lovei and Whittington, 1993). This has been discussed in detail in Chapter 1.

${ }^{78} \mathrm{KMC}$ reserves the discretion after the required water quality checks to allow the water to be sold from the hydrant for drinking purposes.
} 


$\begin{array}{llllllllllllllll}\mathrm{C} & \mathrm{H} & \mathrm{A} & \mathrm{P} & \mathrm{T} & \mathrm{E} & \mathrm{R} & \mathrm{F} & \mathrm{O} & \mathrm{U} & \mathrm{R}\end{array}$

WATER VEN DING I N KA RA C H I

Table 4-9: $\quad$ Schedule of License Fee for Private Sources of Water Supply (Hydrants and Tanker Trucks) ${ }^{1}$

\begin{tabular}{|c|c|c|}
\hline & Mechanical Power & Rate of Fee \\
\hline a. & 1 H.P. to 5 H.P. & PKR. $300 /$ month ( $\$ 5.7 /$ month $)$ \\
\hline b. & $>5$ H.P. to 10 H.P. & PKR. $400 /$ month ( $\$ 7.6 /$ month $)$ \\
\hline c. & $>10$ H.P to 20 H.P & PKR. $600 /$ month ( $\$ 11.4 /$ month) \\
\hline d. & $>20$ H.P. & PKR. $800 /$ month $(\$ 15.2 /$ month $)$ \\
\hline \multicolumn{3}{|c|}{ 2. Water for puposes other than drinking } \\
\hline a. & 1 H.P. to 5 H.P. & PKR. $200 /$ month $(\$ 3.8 /$ month $)$ \\
\hline b. & $>5$ H.P. to 10 H.P. & PKR. 300/ month ( $\$ 5.7 /$ month $)$ \\
\hline c. & $>10$ H.P to 20 H.P & PKR. $500 /$ month $(\$ 9.5 /$ month $)$ \\
\hline d. & $>20$ H.P. & PKR. $700 /$ month $(\$ 13.3 /$ month $)$ \\
\hline \multicolumn{3}{|c|}{ 3. Vehicles supplying and selling water } \\
\hline a. & Water sold for drinking purposes & PKR. $200 /$ month ( $\$ 3.8 /$ month $)$ \\
\hline b. & Water sold for purposes other than drinking & PKR. $100 /$ month ( $\$ 1.9 /$ month) \\
\hline
\end{tabular}

${ }^{1} \mathrm{~F}$ ee is levied and charged on the mechanical power being used for carrying on the commercial trade

\section{Source: Karachi Metropolitan Corporation, Director Health Services}

The hydrant are charged a fee by KMC based on the mechanical power used for extraction of water, whereas, the tanker trucks are charged on the basis of whether they are selling drinking or non drinking water (Table 4-9). The fee is calculated on a per month basis but is paid annually. In practice, the policy was instituted for reason of health implication of distribution of poor quality water and falls under the public health division of KMC. Furthermore, the designed tariff does not capture the externality cost of the water extracted, neither is the cost of using a public resource as the groundwater has been incorporated.

In sum, the policy for regulating the hydrant owners have failed in its implementation because of two reason, (1) very few hydrants have registered (25 of 106), and no penal action against those that are unregistered has been taken, and (2) the license fee to the hydrant and tanker truck owners does not incorporate the economic value of water from extraction to its final cost to the consumer. Furthermore, KMC does not have a task force that would go out in the field and identify violators, both private hydrants and tanker trucks. 


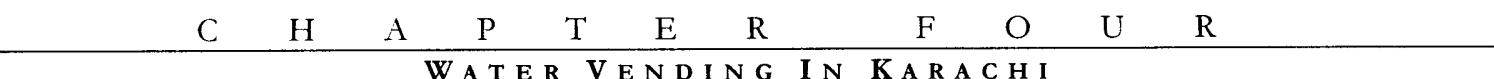

\subsection{Analysis of the Water Distribution in Karachi}

Almost 17,500 tanker trucks, carrying 29.4 million gallons of water (MGD) are distributed daily, of which 16,500 are sold commercially by the tanker truck vendors. Approximately $92 \%$ (27 MGD) of this water is provided by private hydrants owners from groundwater sources. The remaining $8 \%(2.4 \mathrm{MGD})$ is supplied from the government hydrants, which includes supply for its regulated tanker truck delivery to deficient areas and the rest is sold commercially in the city. Only $3 \%$ of the water sold commercially by the vendors in the city is from the KWSB hydrant.

Figure 4-2 summarizes estimates of the daily flows of money and water in Karachi. Private water hydrants provide approximately $8 \%$ of the total water supplied in the city ${ }^{79}$ and the private tanker truck vendors distribute approximately $9 \%$ of the city's domestic water supply. ${ }^{80}$ The unit price of a gallon of water at the private hydrants is PKR. 0.019 (US $\$ 0.10 / \mathrm{m}^{3}$ ), being almost $20 \%$ lower than price of PKR. $0.024 /$ gallon (US $\$ 0.12 / \mathrm{m}^{3}$ ) at the Government Hydrant. This illustrates that private hydrants are setting their price in direct competition with the price at the government hydrant, the latter being lower. However, the unit price of gallon water sold by the tanker truck vendors is PKR. 0.16 (US $\$ 0.8 / \mathrm{m}^{3}$ ), being almost 6 times the unit price of water at the hydrant.

Households in Karachi are spending approximately PKR. 1617.7 (US\$30.9) million on vended water annually or more. Of this amount only PKR. 6.6 (US\$0.1) million goes to the KWSB and the rest remains in the private vending sector in Karachi. In addition, KWSB further pays PKR. 25.0 (US\$0.5) million to the vendors to deliver water under its regulated tanker truck delivery for deficient areas in the city. The per day earning of hydrants owners and vendors combined (PKR. 4,432,000) is comparable to the revenue collected by KWSB (PKR. 4,500,000) from households connected to the piped network system for 1997-98 and

${ }^{79}$ According to the information in PSP Strategy document it suggest that private hydrant provide approximately $10 \%$ of the total water supply, which would equal 31.5MGD.

80 This figure includes both the contractual and commercial vending by tanker trucks 


$\begin{array}{llllllllllll}\mathrm{C} & \mathrm{H} & \mathrm{A} & \mathrm{P} & \mathrm{T} & \mathrm{E} & \mathrm{R} & \mathrm{F} & \mathrm{O} & \mathrm{U} & \mathrm{R}\end{array}$

W A T E R V E N D I N G I N K A R A C H I

Figure 4-2: Daily money and water transaction in Karachi, Pakistan ${ }^{81}$
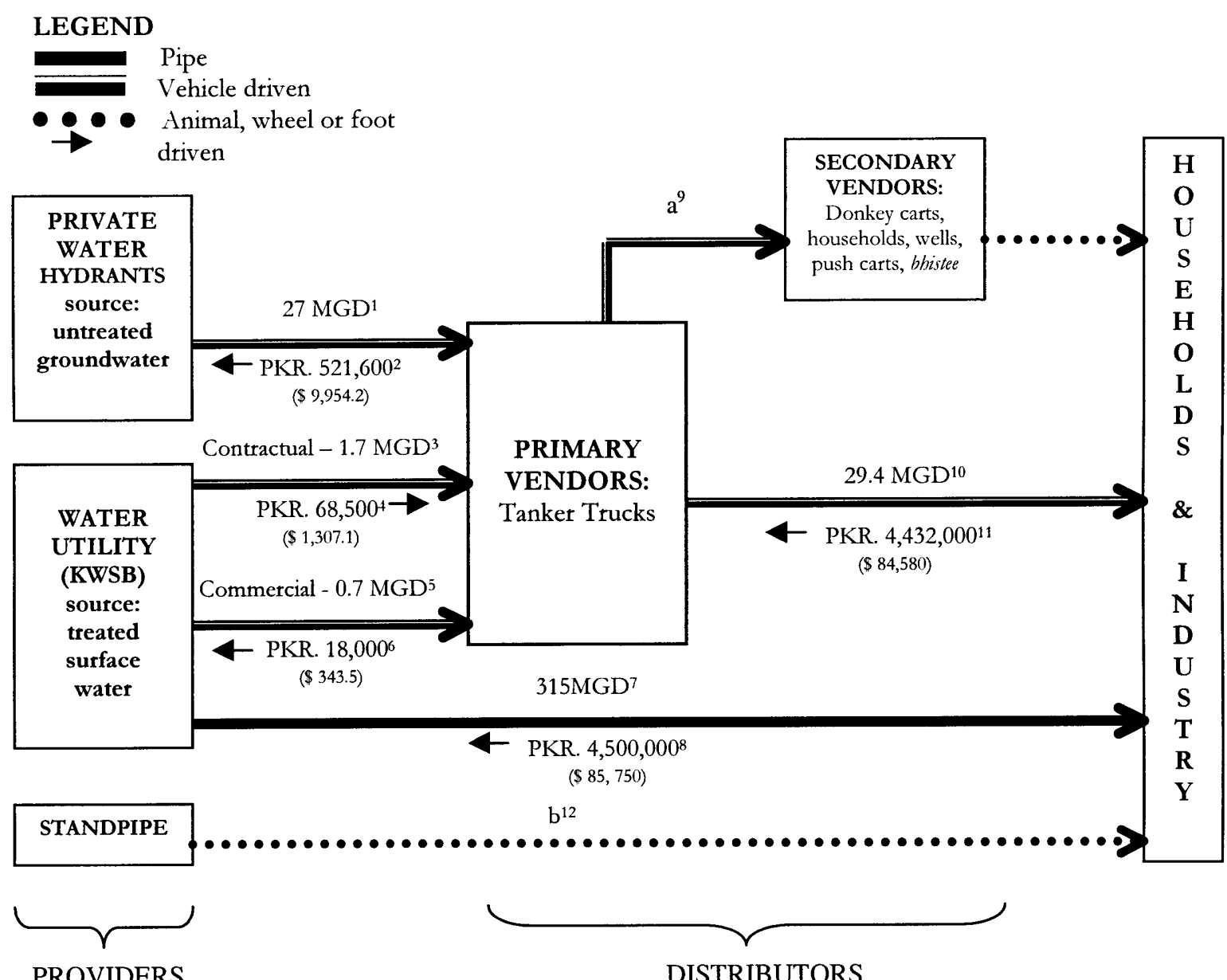

PROVIDERS

DISTRIBUTORS

${ }^{1}$ Assuming 4000 trucks making 4 trips per day, a weighted average of 1650 gallons is used for the volume of each truck ( $62.5 \%$ have a volume of 1200 gallons; $37.5 \%$ have a volume of 2400 gallons).

${ }^{2}$ As already known, the average price of a 1200 and 2400 gallon tanker truck at a private hydrant is PKR. 23.3 and PKR. 48.0 respectively. A weighted average of PKR. 32.6 is used for calculating the revenues for the private hydrants $(62.5 \%$ have a volume of 1200 gallons; $37.5 \%$ have a volume of 2400 gallons).

${ }^{3}$ KWSB has sanctioned 1020 tanker trips per day to deficient and tail end. A weighted average of 1650 is used.

4 The annual budget allocated for these contracted trips is PRK. 25.0 million.

${ }^{5}$ Commercial trips sanctioned by KWSB each day are equal to 450 . A weighted average of 1650 is used.

${ }^{6}$ As already known, the average price of a 1200 and 2400 gallon tanker truck at a government hydrant is PKR. 28 and PKR. 56 respectively. A weighted average of PKR. 40 is used for calculating the revenues for the KWSB (62.5\% have a volume of 1200 gallons; $37.5 \%$ have a volume of 2400 gallons).

${ }^{7}$ Water supply by KWSB is 525 MGD; however, $40 \%$ is lost as Unaccounted for Water (UAW).

8 This is KWSB's revenue from water charges, collection arrears and conservancy charges for 1998-99, equal to PKR. 1640 million. Source: KWSB Basic Facts 1998-99.

${ }^{9} \mathrm{~A}$ small percentage of all the water sold in Karachi is sold to the secondary vendors, who then sell it further at the neighborhood level. Since it was beyond the scope of the study to estimate the quantity of water being sold by secondary vendors, it is being assumed to be negligible as compared to tanker trucks.

10 This number is cumulative of water sold by private hydrants and government hydrants $(27+0.7 \mathrm{MGD})$.

11 A weighted average of PKR. 267.15 (PKR. 0.16/gallon) which is derived from the tankers, reported selling prices of 1200 and 2400 gallons tanker truck, averaged over season and sources (the average price of a 1200 gallons tanker is PKR. 188 and for 2400 gallons the average price is PKR. 374).

12 Water supply in Karachi is not metered, due to which the quantity of water supplied through standpipes is not indicated in any document published by KWSB and tariff is on basis of unconnected customers.

81 This figure is based on estimates collected during fieldwork in Karachi from formal and informal source, to a construct this picture 


\begin{tabular}{ccccccccccccc}
$C$ & $H$ & $A$ & $P$ & $T$ & $E$ & $R$ & $F$ & $O$ & $U$ & $R$ \\
\hline W A T E R & V E E N D I N G & I N & K A R A C H I &
\end{tabular}

for the supply of 315 MGD to the whole city. ${ }^{82}$ This shows that a thriving private water market exists in Karachi, which is wide spread and complex. Although the vending sector does not have a significant market share in quantity supplied, it is still a lucrative business because of the turnover per day for both the tanker truck vendors and the hydrant owners.

The informal water market exists in Karachi, comprising of primary and secondary vendors as distributors and hydrant owners as providers of water. Although, this sector is formally regulated by the Karachi Metropolitan Corporation (KMC), in practice these regulations are rarely enforced as a result of pressure from hydrants and tanker truck owners. As a result vendors operate in a totally unregulated market.

In sum, water-vending sector constitute a very small portion $(8 \%)$ of the total water supply to the city ( 315 versus 27.7 ). However the revenue returns of the vendors are comparable to those of the utility (KWSB), indicating potential of water markets operating in an unregulated market.

\subsection{Conclusion}

The above discussion about the water vending industry brings to focus the following issues:

\footnotetext{
- The vending industry in Karachi shows characteristics of competitive industry

- Structure of the Vending Industry

- $\quad$ Rent Seeking behavior of Hydrant Owners
}

Chapter Five builds on the finding of this chapter and Chapter Three to argue for the key findings of the study and propose recommendations.

\footnotetext{
82 According to KWSB - Basic Facts 1998-99, the total receipt budget for KWSB was in the amount of PKR. 1778 million, which included water, charges, subsidy, capital receipts and conservancy and fire tax.
} 
\begin{tabular}{ccccccccccc} 
C & $H$ & A & $P$ & $T$ & $E$ & $R$ & F & I & V & E \\
\hline CONCLUSIONS & AND POLICY SugGeSTIONS
\end{tabular}
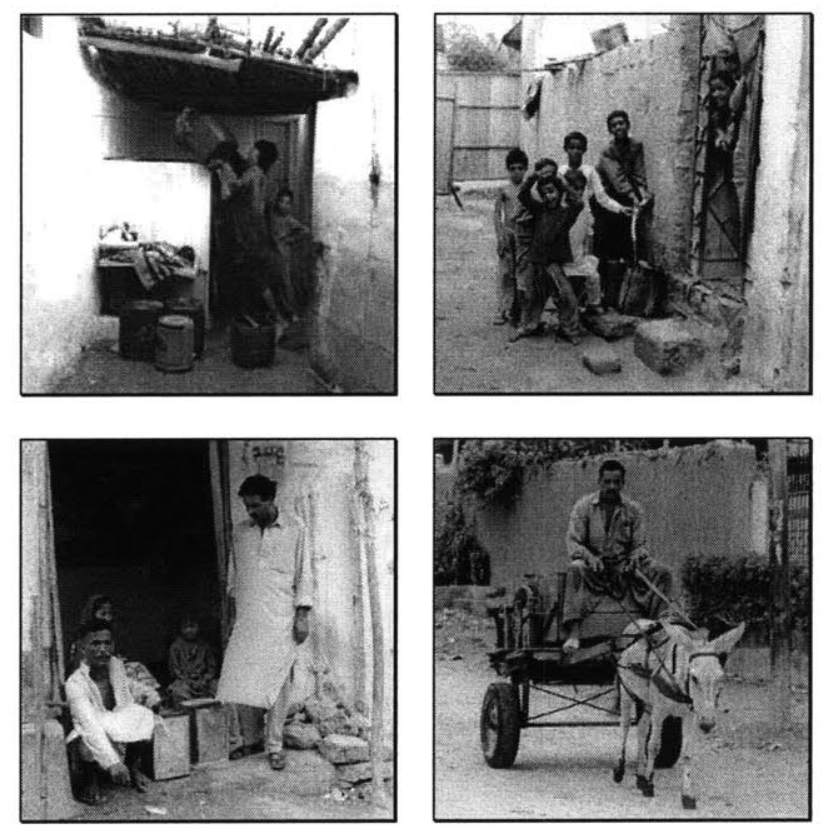


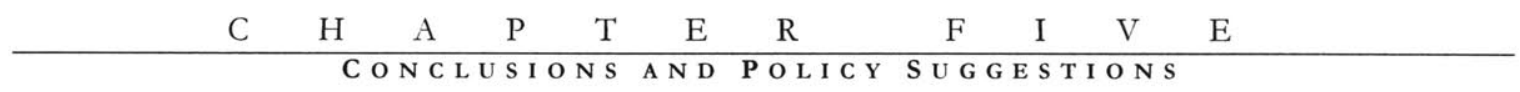

Previous chapters have described the overall water supply situation in Karachi in the context of both formal and informal water delivery systems. As the Karachi Water and Sewerage Board (KWSB) is unable to meet the households' demand for water, households rely on water vending as a supplementary source of water supply. Unlike the majority of the cases in the water vending literature, clients of the vending industry in Karachi consist of households with a wide variety of socioeconomic characteristics and levels of water supply. This Chapter presents three key findings, as well as recommendations for several policy reforms to Karachi's water sector. Although these findings are specific to the case of Karachi, they help extend the understanding of water vending's role in water supply for urban areas in developing countries.

\subsection{Main Findings}

\section{Nature of the water vending market in Karachi}

The water vending market in Karachi has some distinctive characteristics. Although the vending market provides only $9 \%$ (30 of 344 MGD) of the water consumed by city resident on a daily basis, it earns almost $50 \%$ of the all revenues expended on water (PKR. $4,432,000(\$ 84,580)$ of $8,932,000(\$ 170,458)) .{ }^{83}$ Consequently, water vending in Karachi has a small market share in terms of volume but a significant market share in terms of monetary flows, comparable to those of KWSB (Figures 5-1 and 5-2).
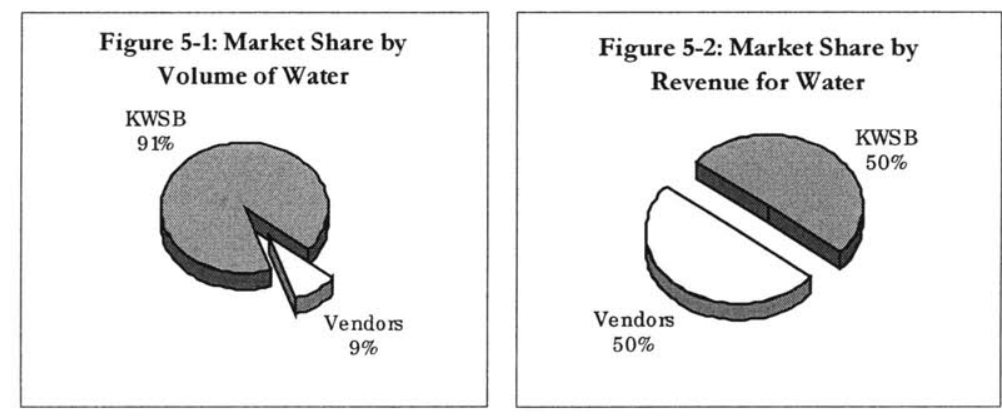

Researchers have also documented similar discrepancy in the market share of water and revenues commanded by water vending in other developing countries, but Karachi

${ }^{83}$ According to an estimate, households in Karachi spend approximately PKR. 1618 million ( $\$ 30$ million) annually on $11,000 \mathrm{MG}$ of vended water from both ground (private hydrants) and surface (KWSB) water sources (fieldwork, 1999). 


$\begin{array}{ccccccccccc}\text { C } & \text { H } & \text { A } & \text { P } & \text { T } & \text { E } & \text { R } & \text { F } & \text { I } & \text { V } & \text { E }\end{array}$

represents one of the most extreme examples of this skewed distribution. In Nigeria, for example, the private water vending system supplies $66 \%$ (2.96 of $4.46 \mathrm{MGD}$ ) of the water consumed daily in the dry season and earns $96 \%(\$ 28,000$ of $\$ 29,100)$ of the revenues (Whittington et al., 1991). In this case, the larger share of revenues is associated with a larger share of the water delivered through vending. Compared with Karachi, no other case was found in which vendors supplied so small a proportion of a community's water and received so large a share of all water supply services' revenues. There are several reasons for this wide difference in volume of water and revenue share in Karachi, and can be explained by three important observations.

First, the water supplied by KWSB per day does not approach the city's effective demand for water. By KWSB's own estimates, gross demand for water by Karachi's households is on the order of 600MGD; the utility is only able to supply 315MGD. Because the utility is unable to provide sufficient service, households turn to the private sector to meet their water supply needs. The money the households spend in the private sector is money that KWSB loses. Second, KWSB charges a low tariff for water, which is unrelated to the volume, consumed by households. Finally, KWSB collects only $23 \%$ of tariff receipts, and thus is unable to cover its operation and maintenance costs, much less fund needed repairs and improvements.

\section{Failure to recognize the common property nature of the ground water}

The KMC \& KWSB do not recognize that the groundwater supplying households' wells and private hydrants is a common property resource. ${ }^{84}$ As a result, existing government policy fails to address the consequences of unregulated private groundwater use. Anyone with sufficient capital can construct a hydrant and begin selling extracted groundwater as a private good, and pay only a nominal fee to the KMC for this privilege.

\footnotetext{
${ }^{84}$ Common property resource is defined, as a resource owned in common rather than privately. Entitlements to use common property resource may be formally protected by specific legal rules, or may be informally protected by tradition and customs. Common property resource regimes exhibit varying degrees of efficiency and sustainability, depending on the rules, which emerge from collective decision-making. While some very successful examples of common property regime exists, unsuccessful examples are even more common (Tietenberg, 1996).
} 


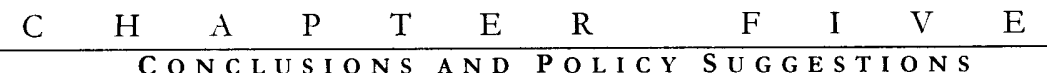

KMC's effort to register private hydrants has been motivated entirely by its interest in regulating it as commercial activity (trade); public health was the main reason for the enactment of these regulations. Despite their effort, only $24 \%$ of the hydrants (25 of 106) in the city are registered. Moreover, regulation attempts by $\mathrm{KMC}$ have been fairly unsuccessful. Because KMC and KWSB do not regulate access to groundwater, private hydrant owners are able to capture the full value of the resource in private markets. As a result, hydrant owners' earnings are on average 40 times those of other unskilled laborers in Karachi.

Existing regulations also fail to deal with the externalities ${ }^{85}$ private hydrants impose on the society as result of groundwater extraction. Each marginal withdrawal of groundwater imposes four kinds of external cost on society: 1) water extracted for one use (or user) is not available for another use (or user) and hence incurs an opportunity cost of the value in the next best use; 2) as the aquifer depletes, each extraction further lowers the declining level of the ground water table and thereby increases pumping costs for all other users; 3 ) the decline in the ground water table causes land subsidence and thereby increases flooding and risks serious damage to buildings and roads; and 4) the decline in the ground water table increases the salinity of the groundwater, which reduces its quality for other users and damages pumps (Porter, 1996). ${ }^{86}$ Although little is known about the condition of Karachi's ground water table and the effects of unregulated extraction by hydrant owners on it, there is evidence that ground water extraction is causing land subsidence and damaging roads where clusters of hydrants are located. ${ }^{87}$

\section{Nature of the demand for vended water}

Another significant finding of this study pertains to the nature of the demand for vended water in Karachi. It shows that a market for vended water exists even in a city with a high proportion of households served by piped water connections $(78 \%)$. When levels of the

\footnotetext{
${ }^{85}$ Externality exists when an action by either a producer or consumer that affects other producers or consumers, yet is not accounted for in the market price (Pindyck and Rubinfeld, 1992).

86 According to Porter the correct policy response to the depletion of the aquifer is a tax on users to reflect the external costs they impose on others users.

${ }^{87}$ DAWN Newspaper.
} 


\begin{tabular}{lllllllllll}
$\mathrm{C}$ & $\mathrm{H}$ & $\mathrm{A}$ & $\mathrm{P}$ & $\mathrm{T}$ & $\mathrm{E}$ & $\mathrm{R}$ & $\mathrm{F}$ & $\mathrm{I}$ & $\mathrm{V}$ & $\mathrm{E}$ \\
\hline
\end{tabular}

public utility's service are low - in this case an average of 3 hours of service each day households are forced to turn to other sources to meet their water supply needs.

In communities in many developing countries, vended water is purchased primarily by the poor who cannot afford connections to a piped water network (Zaroff and Okun, 1984; Whittington et al., 1988; Whittington et al., 1989; Lovei and Whittington, 1993; Crane, 1994). In Karachi, however, the demand for vended water exists in all socioeconomic groups and water supply characteristics, a fact that motivates vendors to target wealthier neighborhoods with a relatively high effective demand. Thus, wealthier households with piped water connections and water storage facilities tend to purchase vended water, more frequently than lower income households who are forced to rely more heavily on standpipes and private wells.

\subsection{Policy Implications}

Based on the above findings, two traditional justifications for public sector intervention in the water vending market apply to the case of Karachi: (1) exploitative use of groundwater resources, and (2) rent seeking by hydrant owners. The following policy recommendations address these aspects of Karachi's water service delivery sector and the financial situation of KWSB.

Clearly, the evidence presented in this thesis suggests that KWSB should not maintain the status quo. First, if not addressed directly, exploitation of the existing groundwater resources is likely to continue unabated. It is possible that groundwater is being extracted at a rate greater than it naturally recharges, risking depletion in the future. Second, the quality of water sold by vendors is not likely to improve, with implications on the health and well being of consumers. ${ }^{88}$ Furthermore, hydrant owners have no incentive to treat the groundwater they sell, apart from households' willingness to pay higher prices for treated water (see Chapter 3).

\footnotetext{
88 Research has shown that almost $57 \%$ of all deaths in Pakistan are caused by one disturbingly common factor: dangerously polluted and highly contaminated drinking water (HERALD, April 1992).
} 


\section{$\begin{array}{lllllllllll}\mathrm{C} & \mathrm{H} & \mathrm{A} & \mathrm{P} & \mathrm{T} & \mathrm{E} & \mathrm{R} & \mathrm{F} & \mathrm{I} & \mathrm{V} & \mathrm{E}\end{array}$}

One might argue that, since vendors are providing poor quality water and the KWSB is losing revenues, the water hydrants should be shut down and water delivery through tanker trucks from private hydrants should be completely prohibited in the city. In my opinion, this scenario would have several untenable implications. First, it would generate an outcry from a public already dealing with water scarcity. Second, it would result in an artificial water shortage, which can give rise to inflation of water rates in the black market from government hydrants. ${ }^{89}$ Therefore, the artificial shortage could also cause price inflation of the limited tanker trucks of water being sold commercially from the government hydrants to the consumers. ${ }^{90}$ Third, this approach counters the ideology held by the public authorities that water is a "basic need" (or "merit good"), a minimal consumption level of which should be afforded by all families regardless of their ability to pay. Tampering with the informal water market may result in eliminating this minimal consumption for certain households. Finally, the prohibition of vending would result in the unemployment of approximately 16,000 or more people employed by the vending industry and could broaden the impact to the entire Karachi labor market. Indeed, a previous attempt by KWSB to prohibit vending in March 1997 proved difficult, short-lived and unsuccessful. ${ }^{91}$

I contend that a better interim approach would be to regulate the water vending market in Karachi in ways that address the two primary problems: First lack of compensation for the social costs of groundwater extraction, and second, exorbitant rent seeking by the hydrant owners.

As discussed below, these problems can be addressed in a number of ways:

- Regulate use of groundwater in the form of a volumetric charge levied on the extractor, which would internalize the externality cost of groundwater extraction,

- Rationalize prices of groundwater extracted through metering,

- Regularize by requiring licenses of all vendors to operate, and

\footnotetext{
${ }^{89}$ As already discussed in Chapter Three, KWSB sells water commercially as well as also supplies water through regulated tanker truck delivery to deficient areas in the city from its hydrants.

${ }^{90} \mathrm{An}$ attempt was made in March 1997 by KWSB to seal the private hydrants. One interviewer indicated that the price of a water tanker during the three days the hydrants were sealed had escalated to PKR. 1200 (\$22.9) for a 2400 gallon tanker truck as against the current price of PKR. 400 (\$7.7) for the same volume of water.

${ }^{11}$ Eight hydrants in the south of the city were sealed for three days on the directive of a senior minister on alleged charges of supplying water - unfit for human consumption. However, after 3 days the hydrants were unsealed. Inquiries show that the unsealing took place in the wake of public outcry and protests owing to acute water scarcity (DAWN 6/1/97).
} 
\begin{tabular}{ccccccccccc}
$C$ & $H$ & $A$ & $P$ & $T$ & $E$ & $R$ & $F$ & I & V & $E$ \\
\hline CONCLUSIONS & AND POLICY SUGGESTIONS
\end{tabular}

- Increase supply of commercial vending from the government hydrants to create competition and hold prices of vended water in check i.e. limit the capacity of private hydrant owners to pass on the cost of licensing and groundwater volumetric charge to consumers.

\section{Recommendation 1: Regulate use of Groundwater}

Groundwater extraction should be regulated in the form of a volumetric charge levied on the extractor, which will help internalize the externality cost of groundwater extraction (Porter, 1996). As a starting point, a groundwater quality and water table level study is essential for any future policy initiative related to ground water regulation. Such a study would include data about the rate of ground water depletion compared to its rate of natural recharge, and other water quality issues. This empirical data would assist in determining an annual cap on the volume of water to be extracted by private individuals in the city and the appropriate prices to charge them. The empirical findings of the proposed study about the water quality will help the public agency to invest in appropriate technology for water treatment. In addition, a simulated model can be used to calculate the optimal amount of yearly withdrawal from ground water sources, and to determine the tariff to be charged to hydrant owners for groundwater extraction. The revenues generated through the volumetric charge will improve the utility's financial situation, enabling it to make investments to improve its service.

In order to be able to regulate the use of groundwater, the volume of groundwater withdrawal should be recorded. For this purpose, meters should be installed at private hydrants at each bore hole point of extraction. The meters should be designed such that they are difficult to tamper with. Monthly checks by the utility staff should be conducted. To minimize the opportunity for corruption, staff should be rotated to different areas of the city each month. 


\begin{tabular}{ccccccccccc}
$C$ & $H$ & $A$ & $P$ & $T$ & $E$ & $R$ & F & I & V & E \\
\hline
\end{tabular}

Recommendation 2: Reduce Rent Seeking by Hydrant Owners

The traditional approach to reducing rent seeking in the literature on water vending is to adopt "deregulation" as a policy prescription, and thereby induce competition in the water market. This policy was implemented in Jakarta, Indonesia, where households were allowed to sell water from their private piped water connections to their neighbors. The policy resulted in decreasing the control of vendors and introducing competition between vendors and households (Lovei and Whittington, 1993). The direct benefits of the policy were reflected in the prices of water, which as a result of market liberalization, dropped below the market price of other private water suppliers. As a result, household spending on water in Jakarta, Indonesia decreased. However, deregulating and opening up the sector for more vendors in Karachi may not be advisable, as the water vending industry is primarily supplying groundwater, and as mentioned earlier, imposing an externality on the society. Thus, deregulation and thereby increasing competition alone cannot be the solution to reducing rent seeking among Karachi's private hydrant owners.

The alternate approach to reducing rent seeking, and the strategy that should be adopted in the case of Karachi, is to "regulate" the water vending market. Simultaneously, it is also important to induce competition so that the hydrant owners do not pass along the increased production costs to households - which would result in increasing the price of the vended water. Adopting a dual strategy can solve the problem of rent seeking by hydrant owners in Karachi: regulate and simultaneously promote competition through increased supply at the government hydrant. This dual strategy might not only reduce rent seeking by hydrant owners but also generate revenues for the utility in Karachi.

Regulate - Legalize Vending

The regulatory reform that KWSB should adopt is the legalization of vending in Karachi. KWSB should recognize that, if the market for vending is competitive, vendors are providing a valuable service and their activities should be legitimized (Whittington et al., 1988). In Karachi, tanker truck vendors operate in a competitive market and are earning excessive profits on the water they sell. 


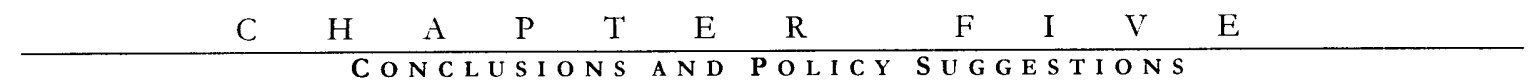

Registration with the utility should be made mandatory for operation, both for hydrant owners and tanker truck vendors. An annual flat fee for registration, as license for operation, should be imposed on the vendors. All hydrant owners and vendors who are not already registered should be identified. Identifying the unregistered vendors should be executed through regular quarterly checks in the city every year by the KWSB staff. To provide incentive for its staff to honestly identify the unregistered vendor, a "reward incentive package" for the staff should be offered. This incentive should not only incorporate financial gains but also professional advancement in the agency. A reward should also be offered to individuals who report an unregistered vendor.

Since vendors are organized and institutionally represented through their respective organizations, ${ }^{92}$ the utility should collaborate with these organizations to identify the vendors operating and not registered. Establishing communication and cooperation with the vendors' organizations can serve the interest of both the KWSB and the vendors. On one hand, it can provide the vendors with an official channel to raise their concerns about issues that affect them, such as the registration fee levied or other similar concerns. On the other hand, the utility can benefit from this relationship by negotiating the regulations to be imposed on vendors through their institutional representative. As a result KWSB would have their support in its implementation of any legal actions taken against certain vendors, such as shutting their business down if they are not registered.

All operations related to licensing and quality checks should be removed from the responsibilities of KMC and consolidated within KWSB. Although this study does not focus on institutions and their restructuring, it strongly suggests that if the institutional responsibilities for regulating the vending sector are not redefined under one institutional cell within the KWSB, the public agency cannot play a positive role in reforming the vending industry in Karachi. The institution cell within KWSB should be autonomous, since links to KWSB's bureaucracy would hamper it from taking actions against vendors or hydrant

\footnotetext{
92 Tanker truck vendors are represented through the Tanker Truck Owners' Welfare Association and hydrants owners through the Hydrant Owners' Association
} 


\begin{tabular}{lllllllllll}
$\mathrm{C}$ & $\mathrm{H}$ & $\mathrm{A}$ & $\mathrm{P}$ & $\mathrm{T}$ & $\mathrm{E}$ & $\mathrm{R}$ & $\mathrm{F}$ & $\mathrm{I}$ & $\mathrm{V}$ & $\mathrm{E}$ \\
\hline COONCLUSIONS & AN D & POLICY & SUGGESTIONS
\end{tabular}

owners, thus foiling the purpose of its creation. Additional effort is needed to determine the appropriate structure of such an institution and its responsibilities.

Vendors should see an advantage in registering with the utility. For example, KWSB could provide technical assistance for treatment and extraction to registered vendors. For this purpose, KWSB can enhance the existing training division, currently only devoted to research in water treatment technologies.

\section{Increase commercial selling at government bydrants}

Groundwater sales can be profitable, as seen from the data collected regarding sales by private hydrant owners. KWSB, however, is realizing only a small proportion of this profit, since it supplies only 0.7 MGD from its hydrants while bulk of its supply comes from surface water. ${ }^{93}$

To improve its financial viability and competition for private hydrants, KWSB should increase the volume of water commercially sold from their own hydrants. For example, approximately 5 MGD per day could be allocated for commercial selling, which would be approximately $20 \%$ of what the private water market supplies (27MGD) from ground water sources. This would force competition and induce a downward pressure on the price of water at private hydrants (i.e. limit the capacity of private hydrant owners to pass on the cost of licensing and groundwater volumetric charge to consumers). As a result, it will force the price of vended water not to escalate above its current level. ${ }^{94}$

\footnotetext{
${ }^{93} \mathrm{Mr}$. Assomal, chief engineer at KWSB, conceded to DAWN that many times these tanker loads from the government hydrants are resold at much higher prices. Mr. Assomal also said that KWSB's own staff and officials were involved in this. Drivers said that distribution of the parchee system at the government hydrants is far from transparent. They said in most cases trips were made to areas where political allies or favorites of the councilors live (Connivance of KWSB officials conceded DAWN 6/20/96).

${ }^{94}$ Hydrant owners set their price in direct competition with the price of water at the government hydrant. The price of water at the private hydrant is $20 \%$ lower than the price at the government hydrant; the price at the KWSB hydrant is already subsidized. Thus increasing supply at the government hydrant would increase the downward pressure on the price for the hydrant owners and therefore induce competition.
} 


\begin{tabular}{|c|c|c|c|}
\hline C & & $\mathrm{F}$ & \\
\hline
\end{tabular}

\subsection{Areas of Future Research}

Although this study has focused on primary vendors, the role of secondary vendors (i.e. donkey carts, kiosks, push carts, bhistee) as important actors in this vending industry should not be ignored. Interestingly, the study shows that secondary vendors charge the highest price for vended water $\left(\sim 2.6 / \mathrm{m}^{3}\right)$ in Karachi. Further research about this sector requires additional key information to ascertain its outreach and to determine target consumers for further policy action: How many secondary vendors are there in Karachi? How does the sector operate? What is its cost and profit structure?

This study also identified that the poor were using standpipes more than tanker trucks or vended sources, raising the question about the level of water supply service to the poor. While this study does not provide conclusions on this issue, it points to a need for further research to determine the levels of water service delivery to the poor in Karachi.

This study attempted to fill the gap in knowledge about the water-vending sector in Karachi. A substantial amount of work still needs to be done to implement regulatory reforms for the water vending sector, a process which will involve understanding the social, political, economic and institutional arrangements of the water markets in more detail. The key findings of this study relate to the nature of the water vending market, failure of the government to recognize the common property nature of groundwater, and the nature of demand for vended water in Karachi. On the basis of these key findings the study concludes that that water-vending sector in Karachi should adopt a dual strategy of regulating and inducing competition, including the regulation of ground water use, the legalization of water vending industry, and the increase of water sales from KWSB hydrants. 
1. ADB. 1993. Water Utilities Data Book: Asia and Pacific Region. Asian Development Bank Publication: Manila.

2. ADB. 1997. Second Water Utilities Data Book, Asia and Pacific Region. Asian Development Bank Publication: Manila

3. Altaf, A., D. Whittington, H. Jamal, and V. K.Smith. 1993. 'Rethinking Rural Water Supply Policy in the Punjab, Pakistan,' Water Resources Research 29(7): 1943-1954.

4. Altaf, M. A., Haroon Jamal, and Dale Whittington. 1992. Willingness to pay for water in rural Punjab, Pakistan. Water and Sanitation Report No. 4. UNDP-World Bank Water and Sanitation Program. The World Bank: Washington, D.C.

5. Black, Maggie. 1999. "Learning What Works: A 20-Year Retrospective View on International Water and Sanitation Cooperation 1978-1998." UNDP-World Bank Water and Sanitation Program: Washington, DC.

6. Brookshire, David S., and Dale Whittington. 1993. "Water Resources Issues in the Developing Countries." Water Resources Research. Vol. 29, No. 7, pp. 1883-1888.

7. Cairncross, S. 1987. "The private sector and water supply in developing countries: Partnership or profiteering?" Health Policy Planning. 2(2): 180-184.

8. Cairncross, S. 1990. "Water Supply and the Urban Poor," Chapter 5 of Cairncross, S., J. E. Hardoy, D. Satterthwaite (eds.), The Poor Die Young: Housing and Health in Third World Cities, Earthscan Publications.

9. Cairncross, S. 1992. "Sanitation and Water Supply: Practical Lessons from the Decade. Discussion Paper No. 9," UNDP-World Bank Water and Sanitation Program. The World Bank, Washington, D.C.

10. Cairncross, Sandy, and Joanne Kinnear. 1991. "Water Vending in Urban Sudan." International Journal of Water Resources Development (U.K.). Vol. 7, No. 4:267-73.

11. Cowen, Penelope Brook. 1994. "Private Sector Participation in the Reduction of Unaccounted for Water (UAW)," Infrastructure Note No. WS 15, World Bank, Transportation, Water and Urban Development Department.

12. Crane, Randall. 1994. 'Water Market, Market Reform and the Urban Poor: Results from Jakarta, Indonesia,' World Development. Vol.22, No. 1:71-83.

13. Davis, Jennifer, Dale Whittington, Harry Miarsono and Asad Khattak. 1997. Household water supply and sanitation conditions and willingness to pay for improved services in three Eastern Islands (Timor, Kalimantan, and Sulawesi), Indonesia. CVM Inc. Chapel Hill, North Carolina.

14. Fass, Simon M., 1982. "Water and Politics: The Process of Meeting a Basic Need in Haiti", Development and Change, Vol. 13, pp. 347-364.

15. Fass, Simon M., 1988. Political Economy in Haiti: The Drama of Survival. Transaction Books: New Brunswick, NJ.

16. Haarmeyer, David and Ashoka Mody. 1998. "Tapping the Private Sector: Approaches to Managing risk in Water and Sanitation," Journal of Project Finance, Vol. 4 No. 2.

17. Hasan, Arif (Eds.). 1998. Community Initiatives: Four Case Studies from Karachi. City Press: Karachi, Pakistan.

18. Hasan, Arif., 1994. Profiles of Three Pakistani Cities: Karachi, Faisalabad, and Thatta. Prepared for the International Institute for Environment and Development (IIED): United Kingdom.

19. Hasan, Arif., 1992. Seven Reports on Housing: Government Policies and Informal Sector and Community Response. OPP-RTI Publication: Karachi, Pakistan.

20. Jellinek, Lea. 1991. The Wheel of Fortune: The History of a Poor Community in Jakarta. University of Hawaii Press: Honolulu.

21. Kasarda, John D., and Allan M. Parnell (Eds.). 1993. Third World Cities: Problems, Policies and Prospects. Sage Publications: Newbury Park, CA.

22. Katko, Tapio S., 1991. "Reselling and Vending Water". American Water Works Association. No 6, 63-69.

23. KDA. 1991. Karachi Development Plan 2000. Prepared by Master Plan and Environmental Control Department, PADCO, Inc., and PEPAC, Ltd. with the assistance of UNCHS, UNDP, Karachi Master Plan 1986-2000. KDA: Karachi, Pakistan

24. Khan, M.A., and Tasneem A. Siddiqui. 1994. "The Incremental Development Scheme". Third World Planning Review. 8:277-291.

25. KWSB, 1998. Private Sector Participation in Karachi Water and Sewerage Board - Draft Feasibility Report. Karachi Water and Sewerage Board: Karachi.

26. KWSB. 1997. Private Sector Participation in Karachi Water and Sewerage Board - Strategy Report. Karachi Water and Sewerage Board: Karachi.

27. KWSB. 1998. Basic Facts 1998-99. Karachi Water and Sewerage Board: Karachi

28. Linn, Johannes. 1983. Cities in the Developing World. Oxford University Press: New York. 


G

29. Lovei, Laszlo and Dale Whittington. 1991. "Rent Seeking in Water Supply.” INU Discussion Paper. World Bank: Washington, D.C. Web site: http://www.worldbank.org/html/fpd/urban/publicat/ws-ws5.html

30. Lovei, Laszlo, and Dale Whittington. 1993. "Rent-Extracting Behavior by Multiple Agents in the Provision of Municipal Water Supply: A Study of Jakarta, Indonesia.” Water Resources Research. Vol. 29, No. 7: 19651974.

31. Marcussen, Lars. 1990. Third World Housing in Social and Spatial Development: the Case of Jakarta. Avebury: Aldershot, UK.

32. McPhail, A.A. 1993. " The 'five percent rule' for Improved Water Services: Can Households Afford More?” World Development. 21:963-973.

33. Mu, Xinming, Dale Whittington, and John Briscoe. (1990). "Modeling Village Water Demand: A Discrete Choice Approach." Water Resources Research. Vol. 26, No. 4. Pp. 521-529

34. Munashinghe, Mohan. 1990. "Water Supply Policies and Issues in Developing Countries." Natural Resources Forum. Vol.2:33-48

35. Pindyck, Robert, and Daniel Rubinfeld. 1992. Microeconomics, Second Edition. Macmillan: New York.

36. Porter, R. C., L. Boakye-Yiadom Jr., A. Mafusire, and B. O. Tsheko. 1997. The Economics of Water and Waste in Three African Capitals. Ashgate Press.

37. Porter, R.C., 1996. The Economics of Water and Waste: A Case Study of Jakarta, Indonesia. Avebury Press.

38. Rogerson, C. M., 1996. "Willingness to Pay for Water: The International Debates." Water SA, Vol. 22 No. 4 October 1996.

39. Schteingart, Martha (Eds.). 1989. Las Ciudades Lationoamericanas en las Crisis: Problemas y Desafios. Trillas Press: Mexico City.

40. Shugart, Chris. 1991. An Exploratory Study of the Water Standpipe - Vendor System in Jakarta. Harvard Institute for International Development. Cambridge, Mass.

41. Singh, Bhanwar., Radhika Ramasubban, Ramesh Bhatia, John Briscoe, Charles C. Griffin and Chongchun Kim. 1993. "Rural Water Supply in Kerala, India: How to Emerge from a Low-Level Equilibrium Trap." Water Resources Research. Vol. 29, No. 7: 1931-1942

42. Tietenberg, Tom. 1998. Environmental Economics and Policy. Addison-Wesley.

43. Vanderschueren, Franz, Emiel Wegelin, Kadmiel Wekete, 1996. Policy Programme Options for Urban Poverty Reduction - a Framework for Action at the Municipal Level. Urban Management Program by the World Bank, Washington, D.C.

44. Whittington, D., D. Lauria, D. A. Okun, and X. Mu. 1988. Water Vending and Development, Technical Report No 45, WASH, USAID, Washington, DC.

45. Whittington, Dale, and Kyeongae Choe., 1992. "Economic Benefits Available from the Provision of Improved Potable Water Supplies," WASH Technical Report No. 77.

46. Whittington, Dale, Donald T. Lauria and Xinming Mu. 1991. "A Study of Water Vending and Willingness to Pay for Water in Onitsha, Nigeria." World Development. Vol.19, No. 2/3:179-198

47. Whittington, Dale, Donald t. Lauria, and Xinming Mu. 1989. "Paying for Urban Services: A Study of Water Vending and Willingness to Pay for Water in Onitsha, Nigeria." Washington, DC: World Bank, INU 40. Web site: http://www.worldbank.org/html/fpd/urban/publicat/rd-ou1.html

48. Whittington, Dale, Donald T. Lauria, Daniel A. Okun and Xinming Mu, 1989. "Water Vending Activities in Developing Countries: A Case Study of Ukunda, Kenya." Water Resources Development. Vol. 5, No. 3, September 1989: 158-168.

49. Whittington, Dale, Xinming Mu, and Robert Roche. 1990. "Calculating the Value of Time Spent Collecting Water: Some Estimates for Ukunda, Kenya." World Development. Vol. 18, No. 2:269-280.

50. World Bank, 1988. "Staff Appraisal Report - Pakistan - Second Karachi Water Supply and Sanitation Project". World Bank: Washington, D.C.

51. World Bank, 1993. "Staff Appraisal Report - Pakistan - Sindh Special Development Project". World Bank: Washington, D.C.

52. Zaroff, Barbara, and Daniel A. Okun. 1984. "Water Vending in Developing countries." Aqua. No. 5: 289 295. 
Questionnaire No:

\section{Section 1 - Background}

1.1 Enumerator (Note for enumerator: Only the head of the household, or his/her spouse should be interviewed)

1. Name of Enumerator

2. Daterime

3. Location of Interview

4. Type of Household Construction

5. Classification of Household

6. Occupancy Status

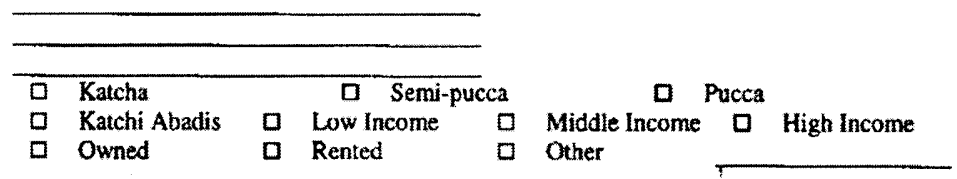

My name is

, and I am student of Massachusetts Institute of Technology, Cambridge, MA. For my thesis research I am looking at how water supply can be improved in the city. I would like to interview you if you can spare 20 minutes. If you feel like not responding to certain questions, you can chose not to answer them.

Thank you.

\subsection{Household}

7. Gender of the Respondent

8. Is this a female-headed household?

9. Total number of people in this household?

10. How many adults $(221)$ live in this household?

11. How many youth (12-20 yr.) live in this houschold?

12. How many children (<12yrs) live in this housebold?

13. Number of hired help

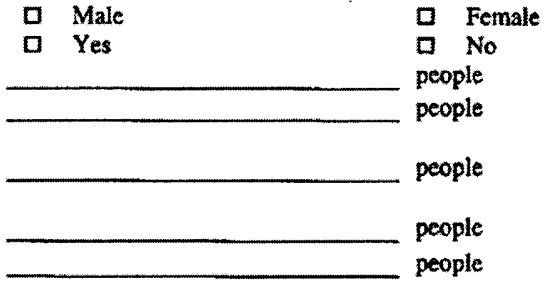

\section{Section 2- Water Sources}

14. Does your household have a private water connection from KWSB?

15. Do you obtain/buy water from any outside source?

16. Identify all the sources that the household obtainshouys water from?

(Mark all those sources that apply)

$\begin{array}{ll}\square & \text { Yes } \\ \square & \text { Yes } \\ \square & \text { KWSB } \\ & \\ \square & \text { Neighbors } \\ \square & \text { Vendors } \\ 0 & \text { Public } \\ & \text { Taps/Standpipe }\end{array}$

$\begin{array}{llll}\square & \text { No } & & \\ \square & \text { No } & & \\ \square & \text { Private Well } & \square & \text { Public Well } \\ \square & \text { Donkey Cart } & \text { 口 } & \text { Boring at home } \\ \square & \text { Kiosks } & \square & \text { Water Tankers } \\ & \text { Other (explain) } & & \end{array}$

(Note for enumerator: If the household has water connection, then cover section 2.1 before moving to cach source independently that is identified by the household as a source that it obtains it water from)

\subsection{Source 1: Karachl Water and Seweraze Hoard}

17. Is your water connection working?

18. Is your water connection legal or illegal?

19. Why have you chosen to connect to the water main illegally?

$\begin{array}{ll}\square & \text { Yes } \\ \square & \text { Legal } \\ \square & \begin{array}{l}\text { Because this is } \\ \text { unauthorized } \\ \text { settlement }\end{array} \\ \square & \text { Everyday }\end{array}$

ㅁ No

D Illegal

The utility has not

been able to

extend the

network

20. How many days per week, on an average, do you get water?

․ Every other day
D There is no check for illegal connections

D Once a weck 
21. When you do get water, how many hours on an average do you get it per day?

22. At what time do you usually get water?

23. Do you use an electric pump/motor for water suction from the water supply network?

24. How much does an electric pump/motor if you were to go and buy it today would cost?

25. How much of the water that your household uses do you obtain from your private water connection?

26. Do you receive a water bill from KWSB?

27. How often do you receive the bill from KWSB?

28. How much was your water bill from KWSB last year?

29. Do you pay your bill from KWSB?

(enumerator, ask if they have a copy and if you can see the copy)

30. Did you pay your water bill from KWSB last year?

31. If no, what are the reasons that you did not pay the bill?

32. For what purpose do you use the water from your private connection? (mark all that apply)

33. How would you judge the quality of water from you connection before boiling in terms of: Taste

Color

Public health risk

(explain, water borne diseases or epidemic)

34. Do you sell water from your connection to neighbors?

35. Do you charge your neighbors per bucket or a fixed fee per month for water from your connection?

36. How much water does each bucket carry?

37. How many buckets do you sell each day on an average?

38. Approximately what were the total revenues last month from sales to neighbors'?

39. What is your opinion about the reliability of water supply by the KWSB in supplying water to your house?

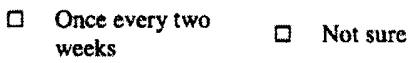

D Once every two weeks

Dot sure

$$
\text { Hrs/day D Not sure }
$$

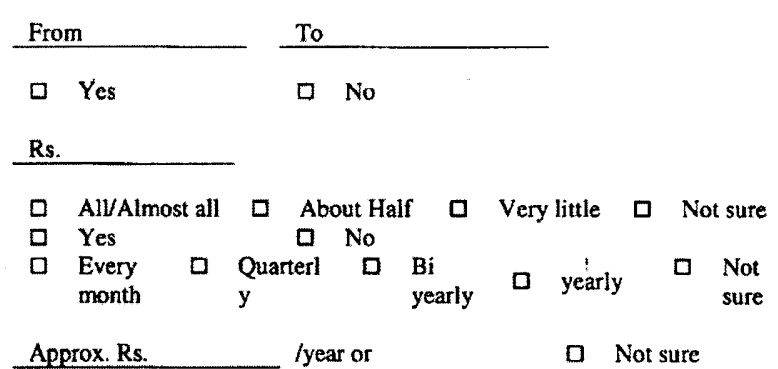

$\square$ Always $\square$ Usually $\square$ Sometimes $\square$ Rarely/Never

ㄴes $\square$ No,

$\square$ Poor water quality $\square$ Unreliable service $\square$ High water rates

Other (explain)

D Drinking

D Washing

ㅁ Cooking

Bathing

Dalty $\square$ Sweet $\quad \square$ Chlorine

$\square$ Normal $\square$ Other $\square$ Not sure

D Dark/Dirty a Clear/Clean Other

D Not sure

ㅁ Very

D Safe

$\square$ Neutral $\square$ Risky

a Very safe

$\square$ Yes $\square$ No

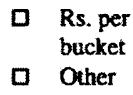

D Fixed fee per month

Litres $/ \mathrm{m}^{3} / G$ allons (mark the right unit)

Buckets, and

Liters

Rs.
D Very Satisfied
- Somewhat Satisfied
$\square \quad$ Satisfied
Less than satisfied
D Not satisfied at all
$\square \quad$ Not sure 'You might have to help to come to this *, like if there was throe tankers and half the tanker the farnily the rest it sells. So if each tanker cost Rs. 200 so in
revenue it gets Rs. $300-1$ probably can take this question out 
40. Why do you think the reliability of water supply by KWSB is good?

41. Why do you think the reliability of water supply by KWSB is bad?

42. What is your opinion about the water quality of the water provided by the KWSB in supplying water to your house?

43. Why do you think the quality water supplied of by KWSB is bad?

44. Why do you think the quality water supplied of by KWSB is good?

45. What do you like least about the water service from KWSB (What would you like most to change)?

46. What is your main complaint about water supply at your household level from KWSB?

47. Overall, how satisfied are you with your water connection from KWSB?

\begin{tabular}{|c|c|c|c|c|c|}
\hline$\square$ & Ample water & 口 & Good distribution & 口 & $\begin{array}{l}\text { Location of your } \\
\text { area }\end{array}$ \\
\hline$E$ & Not sure & 口 & Other (explain) & & \\
\hline E & Shortage of water & 口 & $\begin{array}{l}\text { Administrative } \\
\text { problems }\end{array}$ & $\square$ & $\begin{array}{l}\text { Location of your } \\
\text { area }\end{array}$ \\
\hline & $\begin{array}{l}\text { Water is being } \\
\text { stolen } \\
\text { Other (explain) }\end{array}$ & a & Bad distribution & $\mathbf{\square}$ & Not sure \\
\hline & Very Satisfied & 口 & $\begin{array}{l}\text { Somewhat } \\
\text { Satisfied }\end{array}$ & $\square$ & Satisfied \\
\hline & Less than satisfied & $\square$ & Not satisfied at all & D & Not sure \\
\hline C & $\begin{array}{l}\text { Its not } \\
\text { treated }\end{array}$ & $\begin{array}{l}\text { Its not } \\
\text { treated }\end{array}$ & $\begin{array}{ll}\text { It gets } \\
\text { well } \\
\text { polluted } \\
\text { the way }\end{array}$ & & Not sure \\
\hline & Other (explain) & & & & \\
\hline 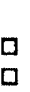 & $\begin{array}{l}\text { Its treated } \\
\text { Other (explain) }\end{array}$ & Its clear & $\begin{array}{l}\text { It tastes } \\
\text { good }\end{array}$ & & ㅁ Not sure \\
\hline C & Poos water quality & 口 & $\begin{array}{l}\text { Breakdowns (no } \\
\text { water) }\end{array}$ & D & High water rates \\
\hline & $\begin{array}{l}\text { Number of hours } \\
\text { of water supply } \\
\text { Other (explain) }\end{array}$ & $\square$ & Quality of water & $\square$ & No complaints \\
\hline
\end{tabular}

\begin{tabular}{llllll}
\hline$\square$ & Very Satisfied & $\square$ & $\begin{array}{l}\text { Somewhat } \\
\text { Satisfied }\end{array}$ & $\square$ & Satisfied \\
$\square$ & Less than satisfied & $\square$ & Not satisfied at all & $\square$ & Not sure
\end{tabular}

2.2 Source 2: Private Well (includes private well and boring at home)

48. Does this household have a private well?

49. Is this a shared private well?

50. How many families share this well?

51. How is the water collected from the well?

52. Approximately, how deep is this well?

53. Approximately, how much time you and your family spend per day to get water from the private well?

54. How often do you get water from the private well?

55. How much of the water that your household uses do you obtain from your private well?

56. For what purpose do you use the water from your well? (mark all that apply)

57. How would you judge the quality of water from your private well before boiling in terms of: Taste

\footnotetext{
${ }^{2}$ Becausc of overlap of water and sanitation pipes
}
口 Yes
№ (skip to section 2.3)
口 Yes
ㅁ 2
Electric Pump
D No
$\square$ Other
D Hand Pump
ㄱ $>3$
Feet

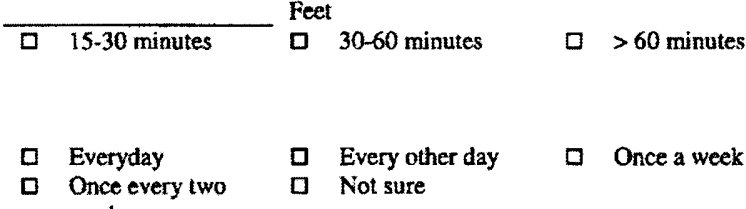 weeks
口 AlVAlmost all
ㅁ About Half
D Very little
D Drinking
ㅁ Cooking
口 Washing
口 Other
․ Bathing

- Salty

口 Normal

S Sweet

ㅁ Chlorine

D Nor sure 


$\begin{array}{llllllllll}\square & \text { Dark/Diny } & & \square & \text { Clear/Clean } & & \square & \text { Other } & \\ \square & \text { Not sure } & & & & & & & & \\ \square & \begin{array}{l}\text { Very } \\ \text { safe }\end{array} & \square & \text { Safe } & \square & \text { Neutral } & \square & \text { Risky } & \square & \begin{array}{l}\text { Very } \\ \text { risky }\end{array}\end{array}$

(explain, water borne diseases or epidemic)

Rs.

口 Yes , or

口 No

59. Do you sell water from your private well to neighbors?

60. Do you charge your neighbors per bucket or a fixed fee per month for water from your private well?

61. How much water does each bucket carry?

62. How many buckets do you sell each day on an average?

63. Approximately what were the total revenues last month from sales to neighbors ${ }^{3}$ ?

64. Overall, how satisfied are you with private well water delivery to you house hold in terms of water quality and availability of water?

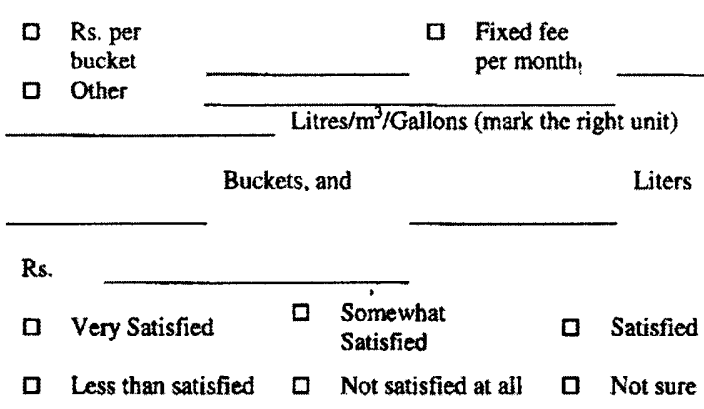

\subsection{Source 3: Public Well}

65. Is there a public well in this neighborhood

- Yes

No (skip to section 2.4)

66. Who is this public well owned by?

$\square \quad$ Individual

D Other (explain)

$\square$ Utility/KWSB $\square$ Not Sure

67. How far is it to the closest public or shared well?

68. How is the water collected from this public or shared well?

69. Does one have to pay to use this shared well?

70. If yes, does one have to pay by the bucket or a fixed amount each month?

71. How much water does each bucket carry?

72. How would you judge the quality of water from the public well in terms of: Taste

Color

Public health risk

(explain, water borne diseases or epidemic)

73. Do you ever get water from the public well?
Feet/Yards/Meters (mark the right unit)
D Electric Pump
口 Hand Pump
ㅁ By bucket
$\square$ Other
Y Yes
Rs. Per
bucket
Fixed fee
per month Other

Litres $/ \mathrm{m}^{3} /$ Gallons (mark the unit that applies)

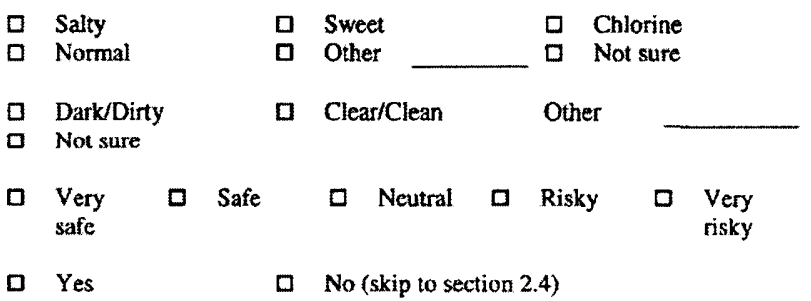

${ }^{3}$ You might have to help to come to this \#, like if there was three tankers and half the tanker the family the rest it sells. So if cach tanker cost Rs. 200 so in revenue it gets Rs. 300 . 
74. Approximately, how much time you and your family spend per day to get water from the public well (in real how much time)?

\begin{tabular}{|c|c|c|c|c|c|}
\hline ㅁ & $15-30$ minutes & $\square$ & 30-60minutes & $\square$ & $>60$ minutes \\
\hline $\begin{array}{l}\square \\
0\end{array}$ & $\begin{array}{l}\text { Everyday } \\
\text { Once every two } \\
\text { weeks }\end{array}$ & $\begin{array}{l}\square \\
\square\end{array}$ & $\begin{array}{l}\text { Every other day } \\
\text { Not sure }\end{array}$ & $D$ & Once a week \\
\hline $\begin{array}{l}\square \\
\square\end{array}$ & $\begin{array}{l}\text { Drinking } \\
\text { Washing }\end{array}$ & $\begin{array}{l}\square \\
\square\end{array}$ & $\begin{array}{l}\text { Cooking } \\
\text { Other }\end{array}$ & ㅁ & Bathing \\
\hline$\square$ & All/Almost all & 口 & About Half & ' & Very little \\
\hline & buckets, or & \multicolumn{2}{|c|}{ liters, or } & $\mathrm{m}^{3}$, or & a Not sure \\
\hline & & \multirow{2}{*}{\multicolumn{4}{|c|}{$\begin{array}{l}\text { Litres } / \mathrm{m}^{3} / \text { Gallons (mark the unit that applies) } \\
\begin{array}{l}\text {. No } \\
\text { liters, or } \quad \mathrm{m}^{3} \text {, or } \quad \text { Percentage }\end{array}\end{array}$}} \\
\hline$\square$ & $\begin{array}{l}\text { Yes } \\
\text { buckets, or }\end{array}$ & & & & \\
\hline $\begin{array}{l}\square \\
\square\end{array}$ & $\begin{array}{l}\text { Very Satisfied } \\
\text { Less than satisfied }\end{array}$ & $\begin{array}{l}\square \\
\square\end{array}$ & $\begin{array}{l}\text { Somewhat } \\
\text { Satisfied } \\
\text { Not satisfied at al }\end{array}$ & $\begin{array}{l}\square \\
\square\end{array}$ & $\begin{array}{l}\text { Satisfied } \\
\text { Not sure }\end{array}$ \\
\hline
\end{tabular}

\subsection{Source 4: Neighbors}

83. Are their households in this neighborhood that sell water to their neighbors?

84. How far is it to the neighbor selling water from your house?

Feet/Yards/Meters (mark the right unit)

85. In your idea where do these neighbors get the water they sell from?

86. How is the water collected from source?

87. Does ons have to pay by the bucket or a fixed amount each month?

\section{a Private Well \\ - River \\ 口 Public taps/ Standpipes \\ By pipe to your house}

\section{Rs. Per} bucket

88. How much water does each bucket carry?

89. How would you judge the quality of water from neighbors' water source in terms of: Taste

Color

Public health risk

(explain, water borne diseases or epidemic)

$\begin{array}{llll}\square & \text { Water Tanker } & \square & \text { Water Connection } \\ \square & \text { Public well } & \square & \text { Leakage point } \\ \square & \text { Not sure } & \square & \text { Other } \\ \square & \text { By bucket } & \square \quad \text { Other }\end{array}$

Fixed fee

per month

Other

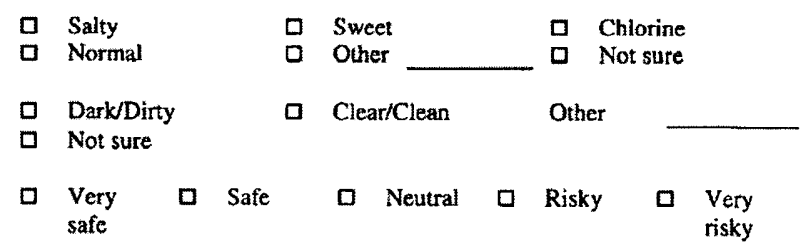


90. Does your household ever obtain its water from neighbors?

91. Approximately, how much time you and your family spend per day to get water from the neighbors?

92. How often do you get water from your neighbors?

93. How much of the water that your household uses for these purposes do you obtain from neighbors?

94. For what purpose do you use the water from the neighbors?

95. Do you have to pay the neighbors to get water?

96. How many buckets do you buy/get each day on an average?

97. Do you use more water from the neighbors during summer?

98. If yes, approximately, how much more each day in summer do you buy/get from neighbors?

99. Overall, how satisfied are you with neighbors water delivery to you household in terms of water quality and availability of water?

\subsection{Source 5: Donkey Cart}

100. Are their households in this neighborhood that buy water from donkey cart vendors?

101. In your idea where do these donkey carts get the water they sell from?

102. Does one have to pay by the bucket or a fixed amount each month to the donkey cart?

103. How much water does each bucket carry?

104. How much water does each donkey cart can carry?

105. How would you judge the quality of water from donkey cart vendors in terms of:

Taste

Color

Public health risk

(explain, water borne diseases or epidemic)

106. Does your household ever obtain/buy water from the donkey cart vendors? $\square$ Yes $\square \quad$ No (skip to section 2.5)

D 15-30 minutes

$\quad 30-60$ minutes

ㄱ $>60$ minutes

D Everyday

D Every other day

ㅁ Once a week

Once every two

口 Not sure weeks

ㅁ Alvalmost all

D About Half

口 Very little

D Drinking

ㄷoking

D Bathing

D Washing

口 Other

D Yes

D No
Liters, br

$\mathbf{M}^{3}$, or $\square$ Not sure
$\square \quad$ Yes
No

buckets, or

liters, or

$\mathrm{m}^{3}$, or Percentage

ㅁ Very Satisfied

D Somewhat Satisfied

口 Less than satisfied

\begin{tabular}{|c|c|c|c|c|c|}
\hline $\mathbf{D}$ & Yes & $\mathbf{D}$ & \multicolumn{2}{|c|}{ No (skip to section 2.6 ) } & \\
\hline $\begin{array}{l}\square \\
\square \\
\square\end{array}$ & $\begin{array}{l}\text { Private Well } \\
\text { River } \\
\text { Public taps } \\
\text { Standpipes }\end{array}$ & $\begin{array}{l}\square \\
\square \\
\square\end{array}$ & $\begin{array}{l}\text { Water Tanker } \\
\text { Public well } \\
\text { Not sure }\end{array}$ & $\begin{array}{l}\square \\
\square \\
\square\end{array}$ & $\begin{array}{l}\text { Water Connection } \\
\text { Leakage point } \\
\text { Other }\end{array}$ \\
\hline Rs & & & $\begin{array}{l}\mathrm{d} \text { fee } \\
\text { month }\end{array}$ & & \\
\hline
\end{tabular}

Litres $/ \mathrm{m}^{3} /$ Gallons (mark the unit that applies)

Litres $/ \mathrm{m}^{3} /$ Gallons (mark the unit that applies)

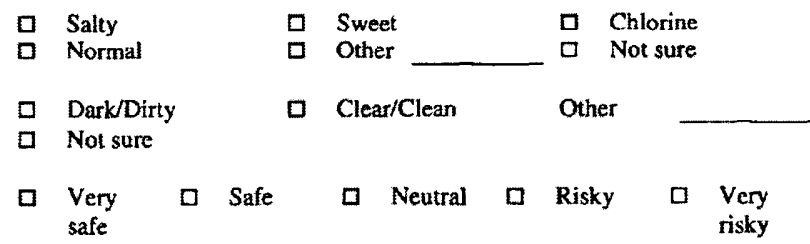

口 Yes D No (skip to section 2.6) 
107. Apptoximately, how much time you and your family spend per day to get water from the donkey cart vendors?

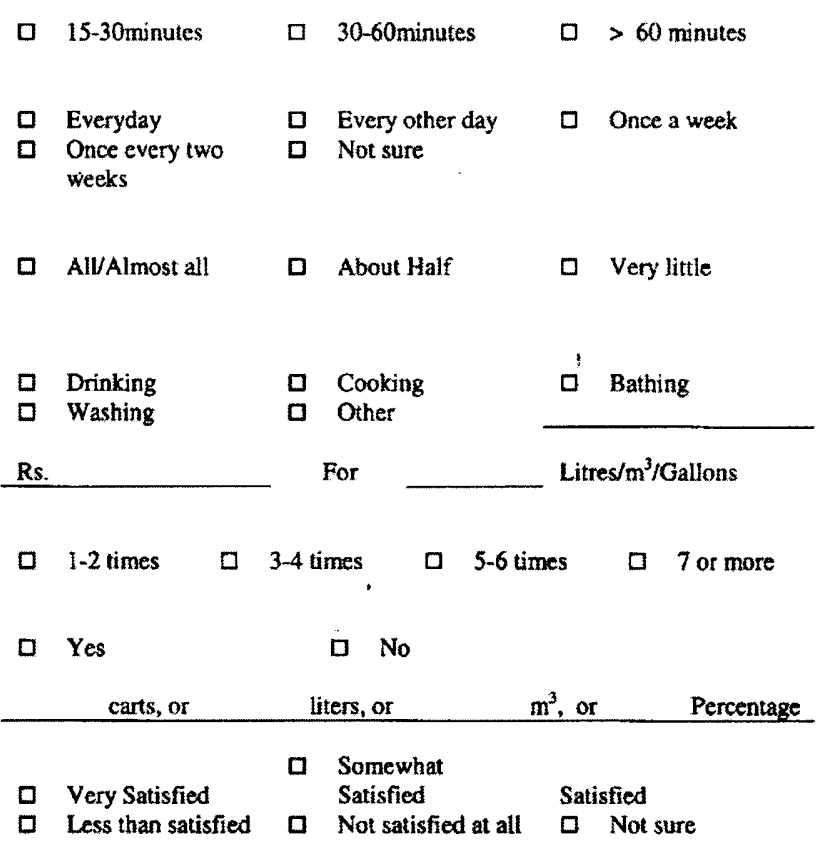

\subsection{Source 6: Public Taps/Standpipe}

113. Are there any public taps in the neighborhood?

a Yes

Do (skip to section 2.7)

116. Who owns this public tap/standpipe?

$\begin{array}{ll}\square & \text { Individual } \\ \square & \text { Other (explain) }\end{array}$

口 Utility/KWSB

$\square \quad$ Not Sure

117. In your opinion what is the source of the water for the public taps/standpipes?

$\begin{array}{ll}\square & \text { Piped system } \\ \square & \text { Ground water }\end{array}$

118. How far is it to the closest public tap/standpipe?

119. How is the water collected from this public or shared well?

120. Does one have to pay to use this public tap/standpipe?

121. If yes, does one have to pay by the bucket or a fixed amount each month?

122. How much water does each bucket cany?

123. How would you judge the quality of water from the public well in terms of:

Taste

Color
D By pipe

D Yes

D Tanker trucks

Other

- Some from each

Feet/Yards/Meters (mark the right unit)

D By bucket $\square$ Other

Rs. Per Fixed fee

bucket __ per month

Other

Litres $/ \mathrm{m}^{3} /$ Gallons (mark the unit that applies)

口 Salty

Normal

口 Sweet

a Chlorine

D Dark/Dirty $\square$ Other

- Clear/Clean
Other 
Public health risk

(explain, water bome diseases or epidemic)

124. Does your household ever obtain its water from public taps?

125. Approximately, how much time you and your family spend per day to get water from public taps/standpipes (in real terms how much time)?

126. Approximately on an average how much is the queuing time?

127. How often do you get water from this public tap/standpipe?

128. For what purpose do you use the water from the public taps/standpipe? (mark all that apply)

129. How much of the water that your household uses for these purposes do you obtain from standpipe/public taps?

130. How many buckets do you buy/get each day on an average from this source?

131. How much water does each bucket carry?

132. Do you use more water from the public taps during summer?

133. If yes, approximately, how much more each day in summer do you buy /get from public taps?

134. Overall, how satisfied are you with public tap water delivery to your household in terms of water quality and availability of water?

\subsection{Source 7: Street Vendors (Mashki)}

135. Are there street water vendors in this neighborhood?

136. In your idea where do these street vendors get the water they sell from?

137. Approximately, how much water does the street vendor carry on him on one trip.

138. Does one have to pay by the bucket or a fixed amount each month to these street water vendors?

139. How much water does each bucket carry?
- Not sure

\begin{tabular}{|c|c|c|c|c|c|c|}
\hline$\square$ & $\begin{array}{l}\text { Very } \\
\text { safe }\end{array}$ & Safe & 口 Neutral & Risky & $\square$ & $\begin{array}{l}\text { Very } \\
\text { risky }\end{array}$ \\
\hline$\square$ & Yes & $\square$ & \multicolumn{4}{|c|}{ No (skip to section 2.7 ) } \\
\hline$\square$ & 15-30minutes & 口 & $30-60$ minutes & $\square>$ & \multicolumn{2}{|c|}{$>60$ minutes } \\
\hline$\square$ & 15-30minutes & $\square$ & $30-60$ minutes & $\square>$ & \multicolumn{2}{|c|}{$>60$ minutes } \\
\hline$\square$ & Everyday & 口 & Every other day & $\square c$ & \multicolumn{2}{|c|}{ Once a week } \\
\hline$\square$ & $\begin{array}{l}\text { Once every two } \\
\text { weeks }\end{array}$ & $\square$ & Not sure & & & \\
\hline $\begin{array}{l}\square \\
\square\end{array}$ & $\begin{array}{l}\text { Drinking } \\
\text { Washing }\end{array}$ & $\begin{array}{l}\square \\
\square\end{array}$ & $\begin{array}{l}\text { Cooking } \\
\text { Other }\end{array}$ & $\square \mathrm{E}$ & \multicolumn{2}{|l|}{ Bathing } \\
\hline
\end{tabular}

$\square$ All/Almost all a About Half $\square$ Very little buckets, or liters, or $\mathrm{m}^{3}$, or $\square$ Not sure Litres/ $\mathrm{m}^{3} /$ Gallons (mark the unit that applies)

$\square$ Yes $\square$ No

buckets, or liters, or

$\mathrm{m}^{3}$, or Percentage

$\begin{array}{llllll} & & & & \text { Somewhat } \\ & \text { Very Satisfied } & & \text { Satisfied } & \square & \text { Satisfied } \\ \square & \text { Less than satisfied } & \square & \text { Not satisfied at all } & \square & \text { Not sure }\end{array}$

\begin{tabular}{llllll}
$\square$ & Private Well & $\square$ & Water Tanker & $\square$ & Water Connection \\
$\square$ & River & $\square$ & Public well & $\square$ & Leakage point \\
$\square$ & $\begin{array}{l}\text { Public taps' } \\
\text { Standpipes }\end{array}$ & $\square$ & Not sure & $\square$ Other \\
\hline
\end{tabular}

Litres $/ \mathrm{m}^{3} /$ Gallons (mark the unit that applies)

Rs. Per

Fixed fee

per month

Other

Litres $/ \mathrm{m}^{3} /$ Gallons (mark the unit that applies) 
140. How would you judge the quality of water from vendors water source in terms of:

Taste

Color

Public health risk

(explain, water borne diseases or epidemic)

141. Does your household ever obtain water from the street water vendors?

142. Approximately, how much time you and your family spend per day to get water from the street water vendors?

143. How often do you get water from the street water vendors?

144. How much of the water that your household uses for these purposes do you obtain from street vendors?

145. For what purpose do you use the water from street water vendors?

146. How many buckets do you buy/get each day on an average?

147. How much do you pay from the vendor each day to deliver water to your doorstep from the water source?

148. Do you use more water from the strect vendors during summer?

149. If yes, approximately, how much more each day in summer do you buy/get from street vendors?

150. Overall, how satisfied are you with street vendors water delivery to you household in terms of wate quality and availability of water?

\section{$2.8 \quad$ Source 8; Kiosks}

151. Are there water kiosks in this neighborhood?

152. How far is it to the kiosk selling water from your house?

153. In your idea where do these kiosks get the water they sell from?

154. How is the water collected from source?

155. Does one have to pay by the bucket or a fixed amount each month?

156. How much water does each bucket carry?

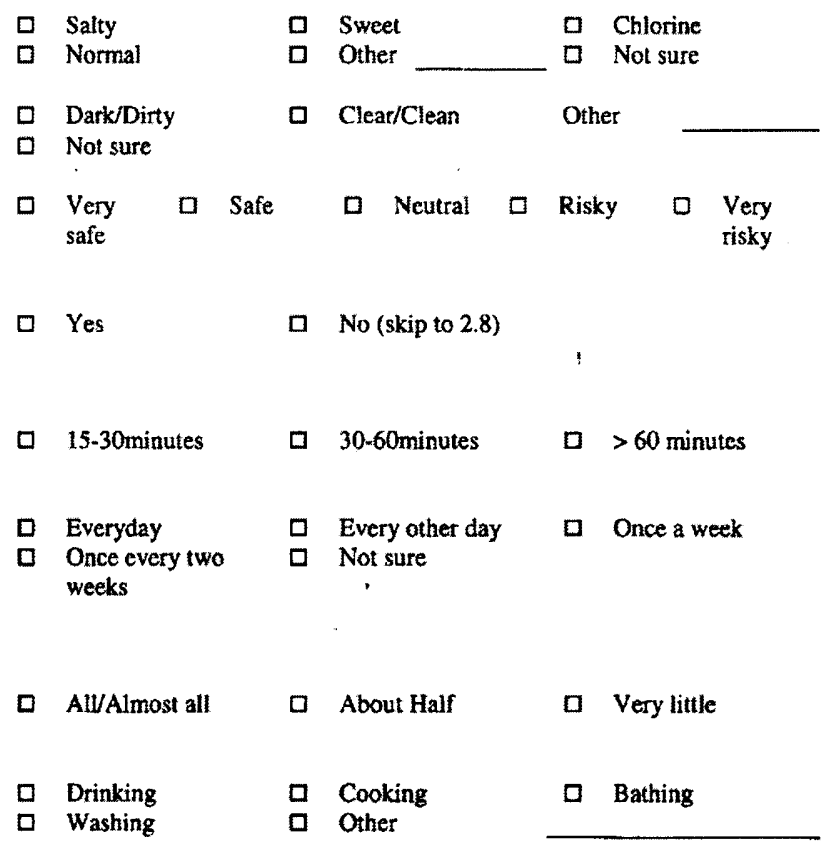

Buckets, or

liters, or

$\mathrm{m}^{3}$, or

Percentage

Rs. frip $\mathrm{O}$ Other

\begin{tabular}{llllll}
$\square$ Yes & $\square$ No & & \\
\multicolumn{1}{c}{ buckets, or } & liters, or & $\mathrm{m}^{3}$, or & Percentage \\
\hline & & $\square$ & $\begin{array}{l}\text { Somewhat } \\
\text { Satisfied }\end{array}$ & $\square$ & $\begin{array}{l}\text { Satisfied } \\
\text { Not sure }\end{array}$
\end{tabular}

$\square$ Yes $\square$ No (skip to section 2.9)

Feet/Yards/Meters (mark the right unit)

$\begin{array}{ll}\square & \text { Private Well } \\ \square & \text { River } \\ \square & \text { Public taps } \\ \text { Standpipes } \\ \square \quad \text { By pipe to your } \\ \text { house } \\ \text { Rs. Per } \\ \text { bucket }\end{array}$

D Water Tanker $\square$ Water Connection

ㅁ Public well $\square$ leakage point

№t sure

a Oher

ㅁ By bucket

$\square$ Other

Other

Litres $/ \mathrm{m}^{3} /$ Gallons (mark the unit that applies) 
157. How would you judge the quality of water from vendors water source in terms of:

$$
\text { Taste }
$$

Color

Public bealth risk

(explain, water borne diseases or epidemic)

158. Does your household ever obtain its water from kiosk?

159. Approximately, how much time you and your family spend per day to get water from the kiosks?

160. How often do you get water from the kiosks?

161. How much of the water that your household uses for these purposes do you obtain from the kiosks?

162. For what purpose do you use the water from the kiosk? (mark all that apply)

163. How many buckets do you buy/get each day on an average?

164. Do you use more water from the kiosks during summet?

165. If yes, approximately, how much more each day in summer do you buy/get from kiosks?

166. Overall, how satisfied are you with kiosks water delivery system to your household in terms of water quality and availability of water?

\subsection{Source 9: Water Tankers}

167. Are their households in this neighborhood that buy water from the water tankers?

168. Why do you think these households buy water from water tankers?

169. Where do you think these water tankers get the water they deliver to these households?

170. Does one have to pay by the tanker or a fixed amount each month to the tanker truck?

171. How much water does each tanker truck carry?

172. How would you judge the quality of water from tanker truck before boiling in terms of:

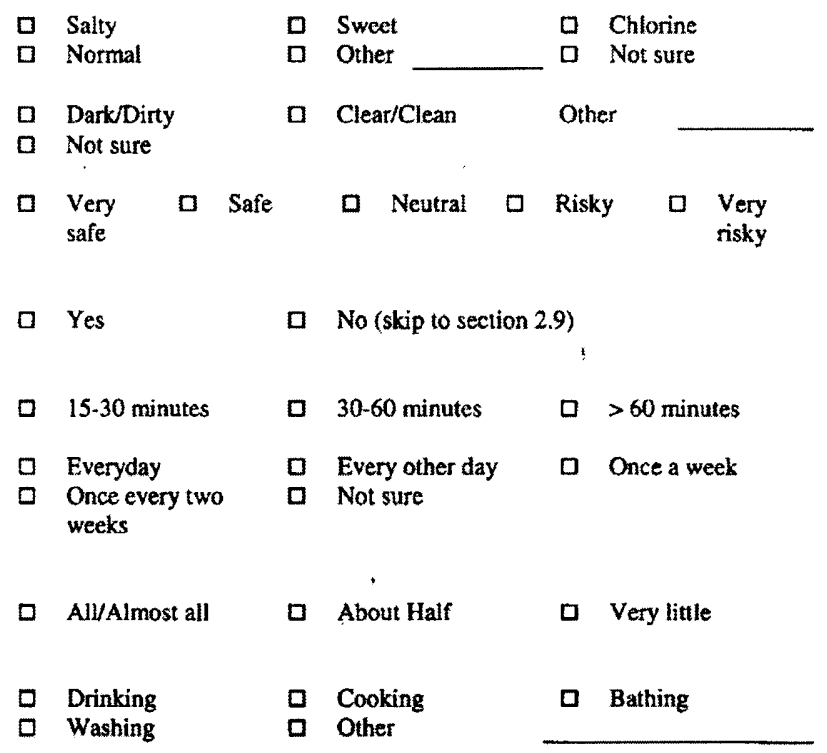

\begin{tabular}{lllll} 
Buckets, or & Liters, or & $\mathbf{M}^{3}$, or & Not sure \\
$\square$ Yes & $\square$ No & & \\
buckets, or & liters, or & $\mathrm{m}^{3}$, or & Percentage \\
\hline
\end{tabular}

$\begin{array}{lllll}\square & \text { Very Satisfied } & \square & \begin{array}{l}\text { Somewhat } \\ \text { Satisfied }\end{array} & \text { Satisfied } \\ \square & \text { Less than satisfied } & \square & \text { Not satisfied at all } & \square \quad \text { Not sure }\end{array}$

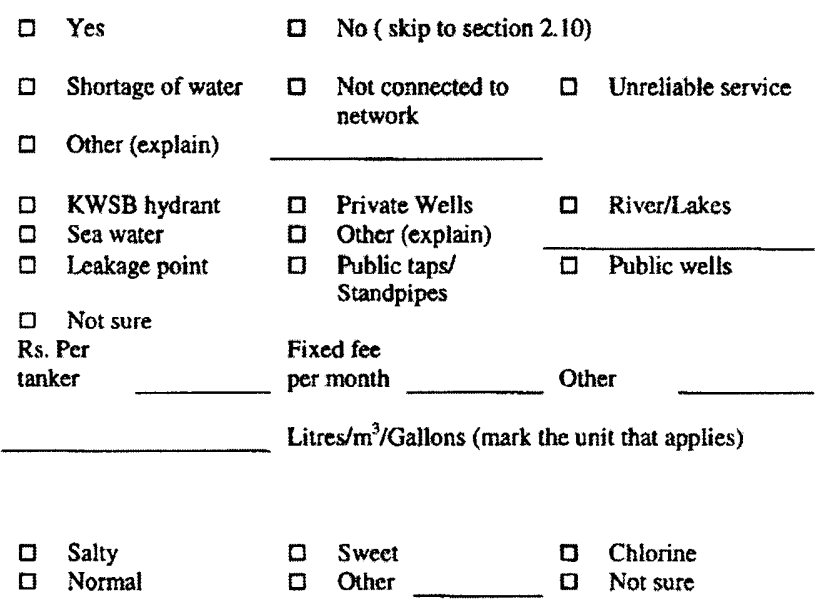


Color

Public health risk

(explain, water bome diseases or epidemic)

\begin{tabular}{|c|c|c|c|c|c|c|c|c|}
\hline $\begin{array}{l}\square \\
\square\end{array}$ & $\begin{array}{l}\text { Dark/Dirty } \\
\text { Not sure }\end{array}$ & & & D & $\mathrm{Cle}$ & Clean & & Other \\
\hline$\square$ & $\begin{array}{l}\text { Very } \\
\text { safe }\end{array}$ & $\square$ & Safe & & $\square$ & Neutral & $\square$ & Risky \\
\hline
\end{tabular}

口 Very

173. Has yoür household ever called for a KWSB tanker due to no water supply or because your area is not connected to the network?

D Yes

口 Very Satisfied

$\square \quad$ Less than satisfied
№

口 Somewhat Satisfied

ㅁ Satisfied your request?

175. How much did you pay for this tanker from KWSB, which was delivered to your house as a I tanker with

Dot satisfied at all

ㅁ Not sure result of the compliant lodged by you?

Rs.

176. How many times in a week do you get a taker from KWSB (try to get the \#)?

177. Does your household ever obtain water from the private water tankers?

Rs.

D 0

$\square \quad 1$

a Yes

D 15-30minutes

tankers?

179. How often do you get water from the tanker trucks?

\section{[. Everyday \\ D Once every two weeks}

180. For what purpose do you use the water from private tanker trucks?

$\begin{array}{ll}\square & \text { Drinking } \\ \square & \text { Washing }\end{array}$

a AlvAlmost all

81. How much of the water that your household uses for these purposes do you obtain from tanker trucks?

182. How much does a water tanker cost in this neighborhood?

183. How much does a water tanker cost in this neighborhood in summers?

184. How many tankers does the family buy in a week?

185. Does the family have underground storage capacity? How much does it cost to install it?

186. What difference do you find between the water delivered from KWSB tanker tnuck (civic center or muslimabad) and Privatc tanker truck (teen hati)?

187. Do you use more water from the tanker trucks during summer?

188. If yes, approximately, how much more each week in summer do you buy/get from tanker truck?

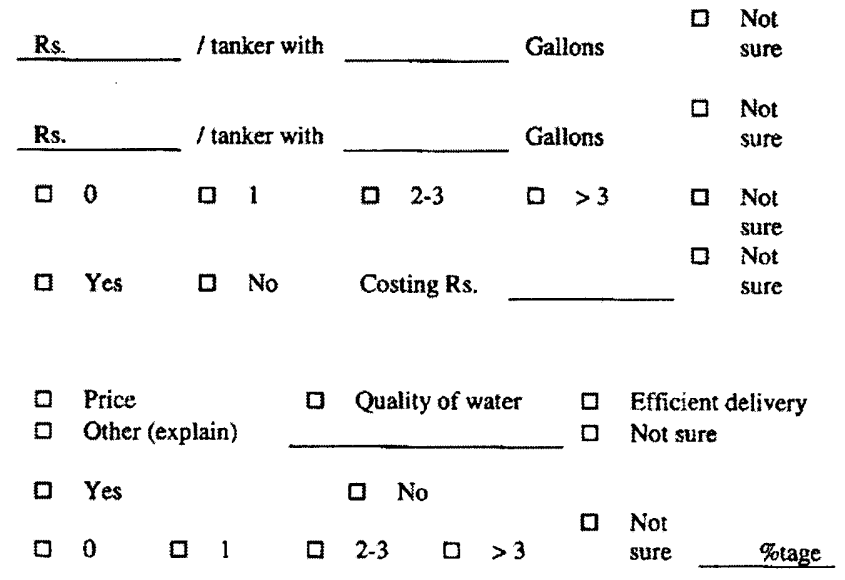


189. Overall, how satisficd are you with private tankers water delivery to your houschold in terms of water quality and availability of water?
ㅁ Very Satisfied
D Somewhat
L Less than satisfied

$\begin{array}{lll}\text { Satisfied } & \text { Satisfied } \\ \text { Not satisfied at all } & \text { Not sure }\end{array}$

2.10 Source 10: Other Surface Water Sources (e.q. Rivers/Streams/Lakes/Ponds)

190. Are therè any rivers/streams/lakes/ponds in this neighborhood where people collect water?

191. Who owns this surface source of water?

192. How far is the nearest surface water source?

193. How is the water collected from source?

194. Does one have to pay to collect water from this source?

195. If yes, does one have to pay by the bucket or a fixed amount each month?

196. How much water does each bucket carry?

197. How would you judge the quality of water from the surface water source in terms of: Taste

Color

Public health risk

(explain, water borne diseases or epidemic)

198. Does your household ever obtain its water from surface sources?

199. Approximately, how much time you and your family spend per day to get water from surface sources?

200. How often do you get water from surface sources?

201. How much of the water that your houschold uses for these purposes do you obtain from surface sources?

202. For what purpose do you use the water from the surface sources of water?

203. How many buckets do you buy/get each day on an average from this source?

204. How much water does each bucket carry?

205. Do you use more water from this source during summer?

206. If yes, approximately, how much more each day in summer do you buy /get from surface water source?

207. Overall, how satisfied are you with surface water delivery to your household in terms of water quality and availability of water?
D Yes

ㅁo (skip to section 2.11)

(- Individual

$\square$ No one

ㅁ Utility/KWSB a Not Sure

Other (explain)

Feet/Yards/Meters (mark the right unit)

By pipe
$\square$ Yes
Rs. Per

bucket

a Other

ㅁ. No (go to 198 )

Fixed fee

per month

Other

Litres $/ \mathrm{m}^{3} /$ Gallons (mark the unit that applies)

$\square$ Salty

] Norma

$\square \quad$ Sweet

C Chlorine

D Dark/Dirty

D Not sure

$\square$ Clear/Clean Other

D Very safe

$\square \quad$ Safe

Neutral $\square$ Risky

Ies

D No (skip to section 2.11)

\begin{tabular}{|c|c|c|c|c|c|}
\hline$\square$ & $15-30$ minutes & $\square$ & 30-60minutes & $\square$ & $>60$ minutes \\
\hline $\begin{array}{l}\square \\
\square\end{array}$ & $\begin{array}{l}\text { Everyday } \\
\text { Once every two } \\
\text { weeks }\end{array}$ & $\begin{array}{l}\square \\
\square\end{array}$ & $\begin{array}{l}\text { Every other day } \\
\text { Not sure }\end{array}$ & $\square$ & Once a week \\
\hline
\end{tabular}

$\square$ All/Almost all $\square$ About Half $\square$ Very little

D Drinking $\square$ Cooking $\square$ Bathing

D Washing $\square$ Other

buckets, or liters, or $\mathrm{m}^{3}$, or $\square$ Not sure

Litres/ $\mathrm{m}^{3} /$ Gallons (mark the unit that applies)
D Yes
№

buckets, or

liters, or

$\mathrm{m}^{3}$, or

Percentage

Satisfied

口 Satisfied 


\section{$2.11 \quad$ Water Storaqe}

208. How much water can you store at your home (mark the correct unit)?

209. Do you have an underground tank?

210. Approximately, how much did it cost you to construct an underground tank?

211. Do you have an overhead tank?

212. Approximately, how much did it cost you to construct an overhead tank?

213. Enumerator: estimate the total number of liters of storage capacity

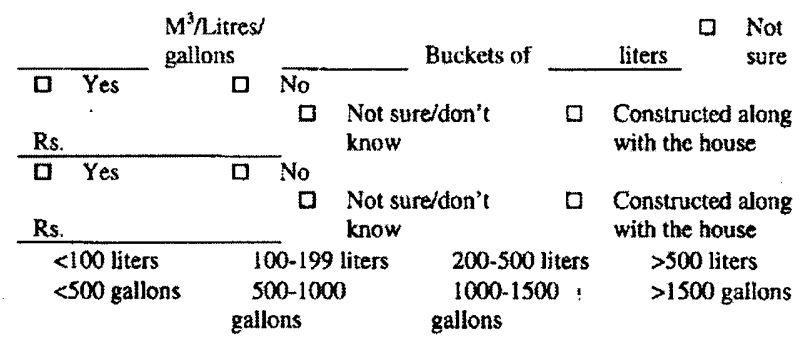

\subsection{Water Boilinu Practices}

\begin{tabular}{|c|c|c|c|c|c|c|c|c|c|c|}
\hline $\begin{array}{l}\text { 214. How often does your household boil its } \\
\text { drinking water? }\end{array}$ & $\mathbf{D}$ & Always & $\square$ & $\begin{array}{l}\text { Mo } \\
\text { the }\end{array}$ & $\begin{array}{l}\text { st of } \\
\text { time }\end{array}$ & $\begin{array}{l}\text { About } \\
\text { half the } \\
\text { time }\end{array}$ & $\square$ & $\begin{array}{l}\text { Less than } \\
\text { half the } \\
\text { time }\end{array}$ & $\mathbf{\square}$ & Never \\
\hline 215. What fuel do you use to boil water? & $\frac{0}{0}$ & $\begin{array}{l}\text { Wood } \\
\text { Electricity }\end{array}$ & & $\begin{array}{l}\square \\
\square\end{array}$ & $\begin{array}{l}\text { Charcoal } \\
\text { Other }\end{array}$ & D & Kerosene & & Gas & \\
\hline
\end{tabular}

\subsection{Summary}

216. Your household gets most of its drinking and cooking water from:

218. Overall, how satisfied are you with your water sources and situation?

219. What is the reason you have not connected to water supply system

220. Do you buy water from other sources in addition to you home water connection from the urility?

221. If yes, what are the reasons that you opt to buy water from other sources in addition to your house connections?

\begin{tabular}{|c|c|c|c|c|c|}
\hline $\mathbf{0}$ & KWSB/private connection & 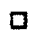 & Private & 口 & Public Well \\
\hline D & Neighbors & $\square$ & $\begin{array}{l}\text { Donkey } \\
\text { Cant }\end{array}$ & $\square$ & Surface water \\
\hline$\square$ & Vendors & D & Kiosks & $\mathbf{D}$ & Water Tankers \\
\hline 口 & Public Taps/Standpipe & ㅁ & Other & & \\
\hline $\mathbf{\square}$ & KWSB & $\mathbf{0}$ & $\begin{array}{l}\text { Private } \\
\text { Well }\end{array}$ & D & Public Well \\
\hline $\mathbf{\square}$ & Neighbors & 口 & $\begin{array}{l}\text { Donkey } \\
\text { Cart }\end{array}$ & 口 & Surface water \\
\hline 口 & Vendors & $\mathbf{D}$ & Kiosks & $\square$ & Water Tankers \\
\hline$\square$ & Public Taps/Standpipe & $\mathbf{0}$ & Other & & \\
\hline$\square$ & Very satisfied & & & & \\
\hline$\square$ & Somewhat satisfied & & & & \\
\hline 口 & Satisfied & & & & \\
\hline $\mathbf{D}$ & Less than satisfied & & & & \\
\hline$\overline{\mathbf{a}}$ & Not satisfied at all & & & & \\
\hline $\mathbf{D}$ & Don't know/ Not sure & & & & \\
\hline$\square$ & $\begin{array}{l}\text { KWSB level of service is } \\
\text { unreliable }\end{array}$ & $\square$ & $\begin{array}{l}\text { Monthly bill } \\
\text { is high }\end{array}$ & $\square$ & $\begin{array}{l}\text { Poor quality of } \\
\text { water }\end{array}$ \\
\hline 口 & $\begin{array}{l}\text { Your area is not connected } \\
\text { to the network }\end{array}$ & $\square$ & $\begin{array}{l}\text { Illegal } \\
\text { connection } \\
\text { is easy }\end{array}$ & ㅁ & $\begin{array}{l}\text { Connection fee } \\
\text { is high }\end{array}$ \\
\hline$\square$ & $\begin{array}{l}\text { Satisfied with current } \\
\text { sources }\end{array}$ & 口 & $\begin{array}{l}\text { Other } \\
\text { (explain) }\end{array}$ & & \\
\hline $\mathbf{D}$ & Yes & $D$ & No & & \\
\hline$\square$ & Poor water quality & $\square$ & Breakdowns & $\mathrm{D}$ & $\begin{array}{l}\text { High water } \\
\text { rates }\end{array}$ \\
\hline$\square$ & Other (explain) & & & $\mathbf{\square}$ & No complaints \\
\hline
\end{tabular}


222. What do you like lcast about the water service from KWSB (What would you like most to change)? $\square \quad$ Poor water quality

$\square \quad$ Other (explain)

D No complaints \begin{tabular}{l}
$\begin{array}{l}\text { Unrcliable } \\
\text { service }\end{array} \quad \square \quad \begin{array}{l}\text { High watcr } \\
\text { rates }\end{array}$ \\
\hline
\end{tabular}

223. How would you feel if your household was given a

. . regular supply through tanker truck as per your

requirement versus water from you private

connection, on the basis that the cost of the tanker is paid up front?

224. If No, why?

\section{Section 3 - Sanitation Practices}

225. Docs your houschold have private water sealed toilct for the exclusive use of the household members? 226. Where are the wastes from your toilet discharged?

227. Does your toilet system function properly?

228. How much would it cost to have a septic tank and toilet like yours?

229. How would you describe your toilet system in terms of:

Cleanliness

Convenience

230. Overall how satisfied are you with your toilet system

231. Do you have a pit latrine?

232. Do you share this pit latrine with other households?

233. How would you describe your pit laterine in terms of:

Cleanliness

Convenience

234. Do you have plans to upgrade your current sanitation system during the next year?

235. In your view what is the most pressing sanitation problem (explain)?

\section{Section 4-Socio-Economic Profle}

Now I would like to ask some questions about this house

(Observe if possible) In what kind of chelling unit or building is

this household living?
ㄱes
口 River/canal
D Fond
D Open drains
D Outside/dry $\square$ Other
land
(explain)
D Sometimes
Rs.
ㅁot sure
口 Not sure

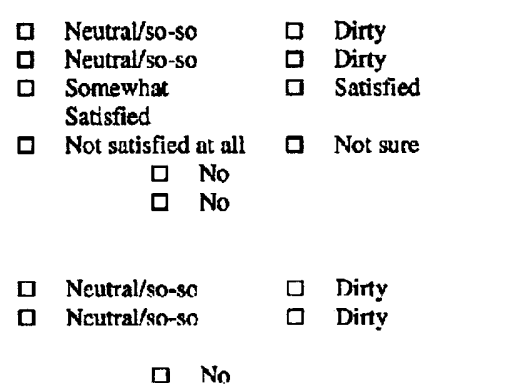

\section{Neutral/so-so}

Good

- Good

Very Satisfied

Less than satisfied

Yes

Yes

a Gond

a Grod

№

D Yas

this household living? (Observe if possible) How many Stories does this housing
unit have

Is there a commercial establishment in this building?

236. Do you own or rent this house?

237. How many rooms does this house have?

238. How many bathrooms does this house have?

239. What is the size of the plot on which this house is constructed?

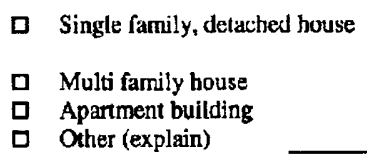

口 Single family, detacbed bouse

a Multi family house

口 Apartment building

$\square$ Other (explain)

\section{Number of floors}
D Yes
D No
Own
D Rent

Number of Rooms, or Number of Rooms, or

Sq. yds/sq. ft. or
D Not Sure

D Not Sure

Not Sure 
240. Approximatcly what is the covered area?

241. Do you have any of the following in your house?

242. Do you have electricity in this house?

243. Approximately, how much was you electricity bill last month?, or What was your household's share of the electric bill?

Eor Owners

244. Do you rent any of the rooms in your house?

245. If you sold your house today, what do you think its market value would be?

246. If you decided to rent your house today, how much rent do you think you would collect for it?

\section{For Renters}

247. What is your current rent?

\section{Household Assets}

248. Can you tell me if anyone in this household owns any of the following items?

249. What is the daily wage rate for an unskilled, bealthy laborer here in Karachi?

\begin{tabular}{llllll} 
& Sq. yds/sq. ft. or & $\square$ & Not Sure \\
\hline$\square \quad$ Lawn/Garden & $\square \quad$ Courtyard & $\square$ & Garage \\
$\square$ Yes & & $\square \quad$ No &
\end{tabular}

Rs./month, or

$\square \quad$ Not Sure
$\square \quad$ Yes
No

Rs., or

ㅁot Sure

Rs./month, or

a Nor Sure

Rs., /month, or

D Not Sure

\begin{tabular}{llllll}
$\square$ & Radio & $\square$ & Bicycle & $\square$ & Sewing Machine \\
$\square$ & Telephone & $\square$ & Television & $\square$ & Motorcycle \\
$\square$ & Satellite Dish & $\square$ & Mobile phone & $\square$ & Automobile \\
$\square$ & Washing machine & $\square$ & Refrigerator & $\square$ & Microwave \\
& & Rs., or & $\square$ & Not Sure \\
\hline
\end{tabular}

\section{Education, relipion 4 , and activities}

Now I would like to ask you some questions about you and your family.

250. What is the highest level of education you have completed?

\begin{abstract}
251. Are you married
252. What is the highest level of education of your spouse has completed?
\end{abstract}

253. What is your religion?

254. How old are you?

255. Approximately, how many people work in this household?

\section{No education \\ D Completed primary school \\ 口 Completed secondary school \\ ㅁ Completed high school \\ D University degree \\ ㅁ Other (explain)}

ㅁes

$\square$ No education

- Completed primary school

Completed secondary school

ㅁ Completed high school

口 University degree

O Other (explain)
D Some primary school

- Some secondary school

口 Some high school

口 Some university
D No

ㅁ Some primary school

ㅁ. Some secondary school

- Some high school

口 Some university

\footnotetext{
"The predominant religion is islam, so I was not sure about asking a question about religion. $95 \%$ muslims
} 


$\begin{array}{llllllll}A & P & P & E & N & D & I & X\end{array}$

HOUSEHOLD SURVEYS

256. Approximately, what is your household income/month?
口 < Rs. 5000
D Rs. $6000-15,000$
Rs. $16,000-25,000$
D Rs. $26,000-35,000 \quad \square \quad$ Rs. $36,000-45,000$ 口 > Rs. 45,000

Thank you for your time.

Time Ended

Enumerator Info - Please respond to these questions when you finish the interview - Thank you.

\begin{tabular}{|c|c|c|c|}
\hline $\begin{array}{l}\text { Was the person who answered the questions irritated or } \\
\text { nervous during the interview? }\end{array}$ & 口 & Yes & $\square$ \\
\hline How would you rate the overall quality of the interview? & $\begin{array}{l}\square \\
\square \\
\square\end{array}$ & $\begin{array}{l}\text { Good } \\
\text { Average } \\
\text { Bad }\end{array}$ & \\
\hline
\end{tabular}

How many people were listening while you conducted

this interview with the respondent?

people 
Enumerator Information (Please complete this part before starting the interview)

Name of Enumerator

DaterTime

Location of Interview

(please describe whether you are interviewing at a particular govt. hydrant or a private hydrant and in which part of the city)

\section{Section 1 - Background}

My name is _, and I am a student of Dawood College of Engineering and Technology/AERC. For my thesis research I am looking at how water supply can be improved in the city of Karachi. In order to understand the existing water situation in Karachi, we are interviewing tanker truck owners and supplier of water. We want to understand the water vending business because we know that water vendors have a strong interest in the type of water and sanitation services available to the resident of Karachi.

I would like to interview you if you can spare 20 minutes. If you feel like not responding to certain questions, you can chose not to answer them.

\section{YESNO}

1. Are you a Tanker Truck Owner? (go to section 2)

2. Are you a Tanker Truck Driver? (go to section 3)

3. Are you a Hydrant Owner? (go to section 4)

4. Are you a Govt. Contractor or sub contractor for water supply from KWSB's hydrant? (go to section

5. Are you a private contractor who delivers water from private hydrants only?

6. Do you do both 4 \& 5

$\begin{array}{llll}\square & \text { Yes } & \square & \text { No } \\ \square & \text { Yes } & \square & \text { No } \\ \square & \text { Yes } & \square & \text { No } \\ \square & \text { Yes } & \square & \text { No } \\ & & & \\ \square & \text { Yes } & \square & \text { No } \\ \square & \text { Yes } & \square & \text { No }\end{array}$

\section{Section 2 - Tanker Truck Opner}

7. Where do you usually get the water that you sell? (mark all those that apply)

8. How many tanker trucks do you own?

9. How many gallons of water do you carry in your tanker truck and how many of each do you own?

口 Government Hydrant (list)

口 Private Hydrant/Wells (list)

口 Public Well (list)

口 Public Taps/ Standpipes (list)

ㅁ River/Surface sources (list)

- Leakage Point (list)

口 Other (please specify)

\begin{tabular}{lll}
\multicolumn{1}{c}{ Gallons } & $\begin{array}{l}\text { Tanker trucks } \\
\text { Number of Trucks Owned }\end{array}$ \\
$\square$ & 1200 gallons \\
$\square$ & 2400 gallons \\
$\square$ & 3600 gallons \\
$\square$ & 6000 gallons or more & \\
$\square$ & Other (specify) & \\
\hline$\square$ & Number of months & \\
Number of days per week \\
From & All year round & To \\
\hline
\end{tabular}

12. What is a peak season for you?

From

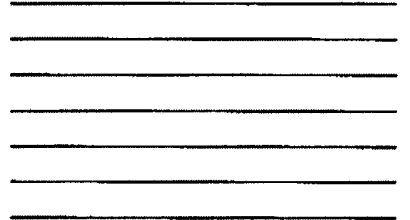

No

No

No

No

13. How many hours does your tanker trick business operate?

From

To 


$\begin{array}{lllllllllllll}A & P & P & E & N & D & I & X & & \text { I } & \text { I }\end{array}$

14. What is the average number of tanker trucks that you sell per day?

15. How many people do you employ to run this

In the peak season
Off-peak season

Tanker trucks operation?

$\ldots$ In the peak season

16. Approximately, how much do you pay a tanker truck driver per month?

17. Are you a contractor for KWSB (or a subcontractor)?

18. If YES, from which hydrant?

19. How many tankers per day do you deliver for KWSB (on parchi)?

20. How many tankers per day do you sell

In the peak season Off-peak season

Tankers trips commercially from the KWSB's hydrant?

In the peak season Rs._Tanker truck $J$ gallons

21. Approximately how much is queuing time at this Tanker truck

gallons source to get water? Off-peak season

22. How much do you pay to fill one tanker truck at these KWSB's hydrant?

23. What is the total cost of one tanker truck of water to them (including cost of filling, bhatta to police. petrol and maintenance)

24. How much do you charge per tanker truck from the KWSB's hydrant?

In the peak season Rs. Tanker truck/ gallons

25. How much approximately do you save on one

the peak season $\mathrm{Rs}$

Mins/Hours/Tanker truck

\begin{tabular}{lll} 
& $\begin{array}{l}\text { Mins/Hours/Tanker truck } \\
\text { Mins/Hours/Tanker truck } \\
\text { Tanker truck/ }\end{array}$ & gallons \\
\cline { 1 - 1 } & Tanker truck/ & gallons
\end{tabular}
tanker truck?

In the peak season Off-peak scason $\mathrm{R}$

26. In what areas or neighborhoods of Karachi do you usually sell water from the KWSB?

27. Most of the water that you sell is for (number this in terms of highest 1,2 , etc.?

28. Approximately how much is this a share of your total sales (this only accounts for the $1^{\text {st }}$ he indicated)?

29. Are you a private contractor who delivers water from the private hydrants?

30. If YES, from which hydrant?

31. How many tankers per day do you sell commercially from the private hydrant?

$$
\begin{gathered}
\text { In the peak season } \\
\text { Off-peak season }
\end{gathered}
$$

Tanker truck $/$ Tanker truckJ

gallons

gallons

B.

D.

E.

$\square$ Other (please specify)

$\square$ Residential use $\square$ lndustrial use $\square$ Commercial use

$\square$ Industrial use $\square$ Otber (specify)

口 $10-20 \% \quad \square \quad 30-40 \%$ 口 $50-60 \%$ 口 $\overline{70-80 \%}$ 口 $90 \% \&$

Yes

№ (go to Qs.40)

ons 
32. Approximately how much is queuing time at this source to get water?

In the peak season

Orf-peak season these private hydrant?

34. What is the total cost of one tanker truck of water to you (including cost of filling, bhatta to police, petrol and maintenance)

35. How much do you charge per tanker truck from the Rs. private hydrant?

$$
\begin{gathered}
\text { In the peak season } \\
\text { Off-peak season }
\end{gathered}
$$

36. How much approximately do you save on one tanker truck trip?

$$
\begin{gathered}
\text { In the peak season } \\
\text { Off-peak season } \\
\end{gathered}
$$

37. In what areas or neighborhoods of Karachi do you $F$. usually sell water from the private hydrants?

38. Most of the water that you sell is for (number this in terms of highest 1,2 , etc.?

39. Approximately how much is this a share of your total sales (this only accounts for the $1^{\text {th }}$ be indicated)?

40. Do you have regular customers that buy water from you every day?

$$
\begin{aligned}
& \text { If NO, skip to next Qs. } \\
& \text { If YES, how many? }
\end{aligned}
$$

41. Do you give regular customers a discount?

If YES, how much do you charge regular customer for

$$
\begin{aligned}
& \text { one tanker truck? } \\
& \text { In the peak season }
\end{aligned}
$$

42. Do you sell regular customers tanker trucks on Off-peak season $\mathrm{Rs}$.

\begin{tabular}{lll} 
& \multicolumn{2}{c}{$\begin{array}{l}\text { Mins/Hours/Tanker truck } \\
\text { Mins/Hours/Tanker truck }\end{array}$} \\
\hline Rs. & Tanker truckJ & gallons \\
\hline Rs. & Tanker truckJ & gallons
\end{tabular}

Rs. Tanker truck

gallons

Rs. Tanker truck/

Tanker truck

gallons

gallons

\begin{abstract}
credit?
\end{abstract}
If YES, how often do regular customers pay you?

43. How much do you charge per tanker truck to your non-regular customers?

$$
\begin{gathered}
\text { In the peak season } \\
\text { Off-peak season } \\
\end{gathered}
$$

44. Do you charge different prices for the tanker truck in different part of the city? (plz give example)

45. What is the thumb rule for determining the price

46. Are customers willing to pay a higher price for water from different water sources (ask him his opinion)? gallons

gallons

Tanker truck Tanker truck

F.

F.

H.

I.

J.

Other (please
specify)

r Residential use $\square$ Industrial use $\square$ Commercial use

口 Industrial use $\square$ Other (specify)

口 $10-20 \%$ 口 $30-40 \%$ 口 $50-60 \%$ 口 $70-80 \%$ D $90 \% \&$

口 Yes $\quad$ No

$\square$ Yes
No

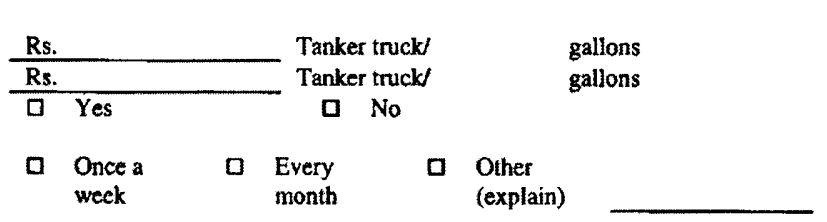

weck month (explain)

\begin{tabular}{lll} 
Rs. & Tanker truck/ & gallons \\
\hline Rs. & Tanker truckJ & gallons \\
\hline
\end{tabular}

Price/Tanker 


$\begin{array}{lllllllllll}A & P & P & E & N & D & I & X & & \text { I } & \text { I }\end{array}$

47. If YES, what water sources do people consider more desirable and why (what does he think this source is)?

Desirable water source

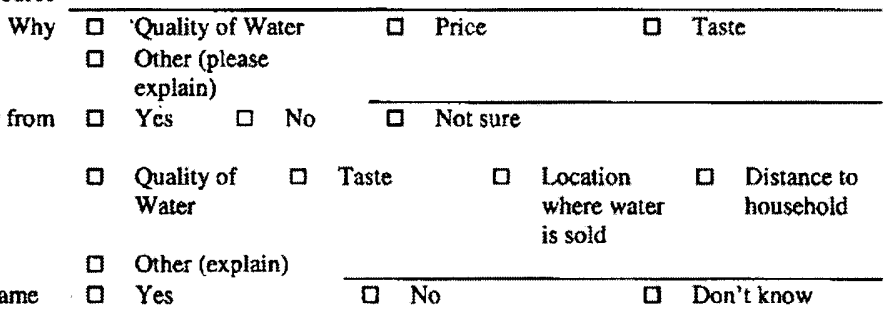

50. Do other tanker tnucks in Karachi charge the same price per tanker as you?

51. What is the approximate expenditure on the tanker Rs. truck everyday (including petrol, maintenance etc.)

52. How much would it cost to buy a tanker truck vehicle like (point towards the vehicle in front)?

53. Are you a member of any professional association? If XES, do you pay a fee every year?

If YES, how much have you paid this year?

54. How many years have you been working in this business?

55. Do you have another job?

$$
\text { If YES, what is this other job? }
$$

56. What was your occupation before you became a water vendor?

57. What is your age?

58. Place of birth?

59. When did you move to Karachi?

60. On average what is your wage per month?

61. Approximately how many tanker trucks get water from this source (hydrant-cumulative average)?

In the peak season

Off-peak season

62. Approximately, how many trips do you thinks these tanker trucks do in a day (hydrant-cumulative average)?

In the peak season Off-peak season

\begin{tabular}{lll}
\hline Rs. & & \\
\hline Rs. & & \\
& & gallons \\
\hline$\square$ Yes & No \\
$\square$ Yes & No. \\
Rs. & years \\
\hline & a No
\end{tabular}

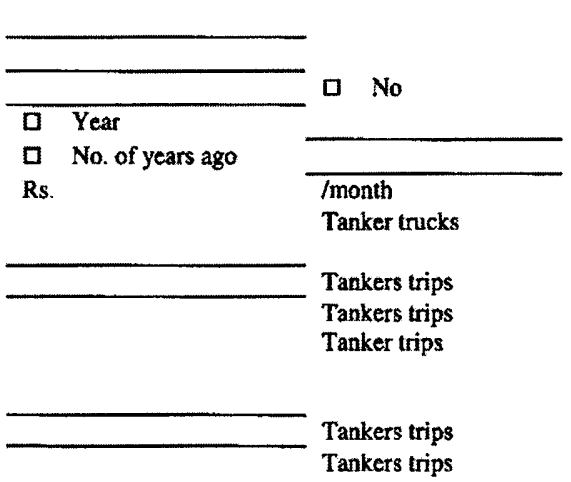

\section{Section 3 - Tanker Truck Driver}

63. Where do you usually get the water that you sell? (mark all those that apply)

64. How many tanker trucks does your owner owns?

65. How many gallons of water do you carry in your tanker truck and how many of each does your

D Government Hydrant (list)

D Private Hydrant/Wells (list)

Đ Public Well (list)

$\square \quad$ Public Taps/ Standpipes (list)

D River/Surface sources (list)

- Leakage Point (list)

口 Other (please specify) tanker truck
owner own?

Tanker trucks

Gallons Number of Trucks Owned 


$\begin{array}{lllllllllll}\text { A } & \text { P } & \text { P } & \text { E } & \text { N } & \text { D } & \text { I } & \text { X } & & \text { I } & \text { I }\end{array}$

(skip if he cannot respond - put notation self for Which he drives)

66. How many days per week do you usually sell water? '

67. How many months a year do you work selling water?

68. What is a peak season for you?

69. How many hours per day do you usually work selling water?

$$
\text { In the peak scason From }
$$

Off-peak season From

70. How many hours does the tanker truck business operate?

$$
\text { In the peak season From }
$$$$
\text { Off-peak season From }
$$

71. What is the average number of tanker trucks do you sell per day?

In the peak season Off-peak season

72. How many people does your owner employs to run this operation?

$$
\begin{aligned}
& \text { In the peak season } \\
& \text { Off-peak season }
\end{aligned}
$$

73. Are you a driver for a KWSB contracter (or a sub-contractor)?

74. If YES, from which hydrant?

75. How many tankers per day do you deliver for KWSB (on parchi)?

76. How many tankers per day do you sell

In the peak season commercially from the KWSB's hydrant?

$$
\text { In the peak season }
$$
Off-peak season $\mathrm{Rs}$

77. Approximately how much is queuing time at this source to get water?

In the peak season
Off-peak season

78. How much do you pay to fill one tanker truck at these KWSB's hydrant?

79. What is the total cost of one tanker truck of water to them (including cost of filling, bhatta to police, petrol and maintenance)

80. How much do you charge per tanker truck from the KWSB's hydrant?

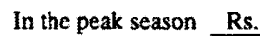

In the peak season $\mathrm{Rs}$. Off-peak season Rs.

Rs.

81. How much approximately do you save on one tanker truck?

$$
\text { In the peak season }
$$$$
\text { Off-peak season } \mathrm{Rs}
$$

82. In what areas or neighborhoods of Karachi do you usually sell water from the KWSB?

Rs.
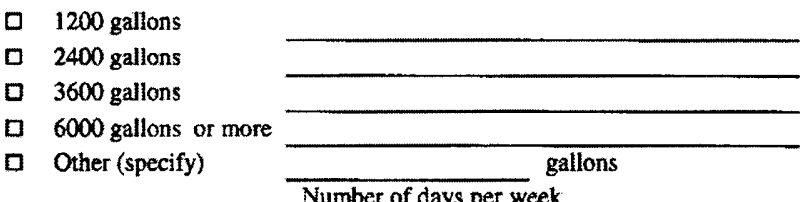

Number of days per week

Number of months

- All year round

From

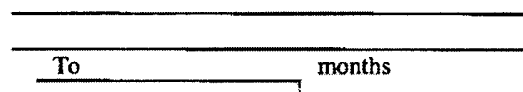

(1)

people
$\square$ Yes $\square$ No (go to Qs. 85 ) Tanker trucks Tanker trucks

To

people

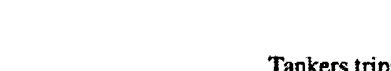

Tanker truck gallons Tanker truck gallons

Mins/Hours/Tanker truck Mins/Hours/Tanker truck

Tanker truck/ gallons

Tanker truck/ gallons

Tanker truck/

Tanker trucks gallons

Tanker truck gallons

Tanker truck/ gallons 
83. Most of the water that you sell is for (number this in terms of highest 1,2 , etc.?

84. Approximately how much is this a share of your total sales (this only accounts for the $1^{\text {st }}$ he indicated)?

85. Are you a private contractor who delivers water from the private hydrants only?

86. If YES, from which hydrant?

87. How many tankers per day do you sell commercially from the private hydrant?

$$
\text { In the peak season }
$$

Off-peak season

88. Approximately how much is queuing time at this source to get water?

In the peak season

Off-peak season

89. How much do you pay to fill one tanker truck at these private hydrant?

90. What is the total cost of one tanker truck of water to you (including cost of filling, bhatta to police, petrol and maintenance)

91. How much do you charge per tanker truck from the private hydrant?

In the peak season Rs. Off-peak season Rs.

92. How much approximately do you save on one tanker truck trip?

In the peak season $\mathrm{Rs}$.

Off-peak season Rs.

93. In what areas or neighborhoods of Karachi do you usually sell water from the private hydrants?

94. Most of the water that you sell is for (number this in terms of highest 1,2 , etc?

95. Approximately how much is this a share of your total sales (this only accounts for the $l^{\text {th }}$ he indicated)?

96. Do you have regular customers that buy water from you every day?

If NO, skip to next Qs.

If YES, how many?

97. Do you give regular customers a discount? If YES, how much do you charge regular customer for one tanker truck?

98. Do you sell regular customers tanker trucks on credit?

H.

l.
D.

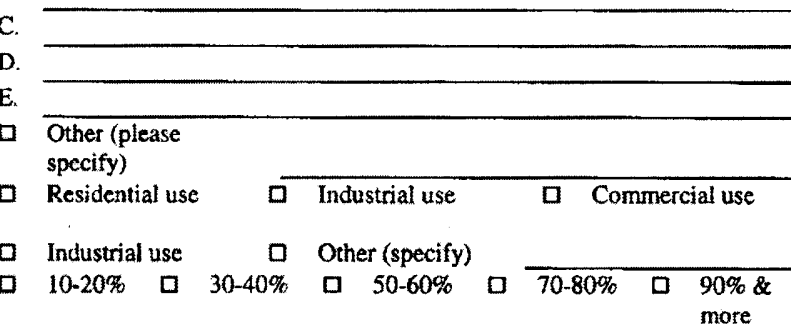

Yes $\quad$ No (go to Qs. 96)

\begin{tabular}{lll}
\hline Rs. & Tanker truckJ & gallons \\
\hline Rs. & Tanker truck/ & gallons
\end{tabular}

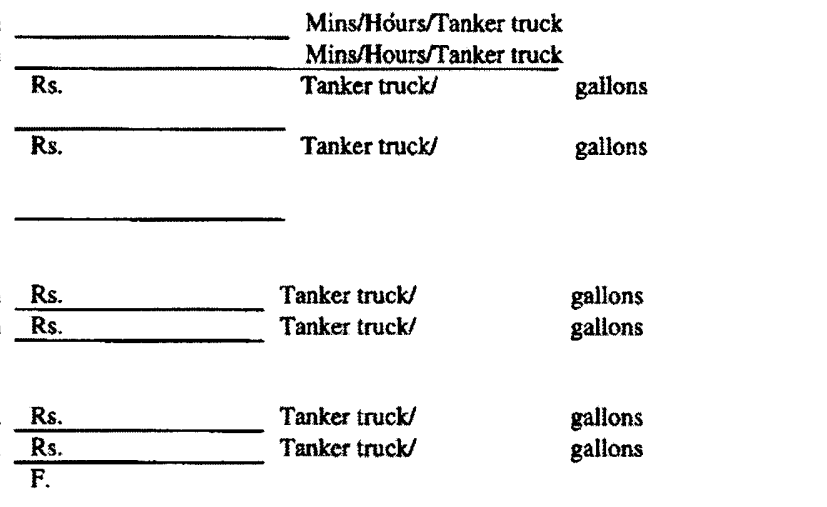

Other (please

specify)

$\square$ Residential use $\square$ Industrial use $\quad \square$ Commercial use

口Industrial use $\square$ Other (specify)

口 $10-20 \%$ 口 $30-40 \%$ 口 $50-60 \%$ 口 $70-80 \%$ प $90 \%$ \&

$\square$ Yes $\square$ No

\begin{tabular}{ll}
\hline$\square$ Yes & $\square$ No \\
& Tanker truck \\
\hline$\square$ Yes & $\square \quad$ No
\end{tabular}


If YES, how often do regular customers pay you?

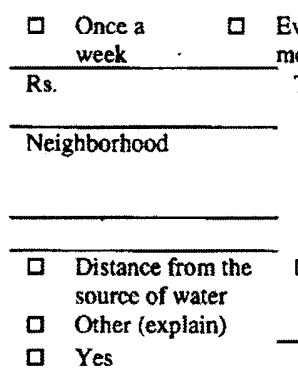

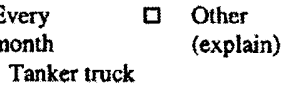

99. How much do you charge per tanker truck to your non-regular customers?

100. Do you charge different prices for the tanker truck in different part of the city? (plz give example)

101. What is the thumb rule for determining the price

102. Are customers willing to pay a higher price for water from different water sources (ask him his opinion)?

103. If YES, what water sources do people consider more desirable and why?

Desirable water source

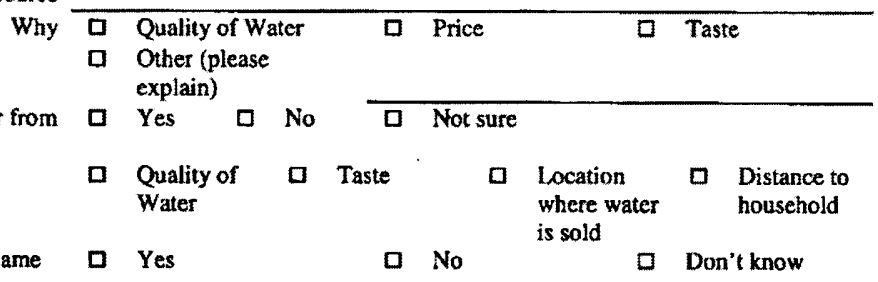

104. Is there a difference in price for a water tanker from the KWSB's hydrant and private hydrant?

105. Why is there this price difference?

106. Do other tanker trucks in Karachi charge the same price per tanker as you?

107. How many years have you been working as a tanker truck driver?

108. Do you have another job?

If YES, what is this other job?

109. What was your occupation before you became a water vendor?

110. What is your age?

111. Place of birth?

112. When did you move to Karachi?

113. On average what is your wage per month?

114. What is the approximate expenditure on the tanker truck everyday (including petrol, maintenance etc.)

115. How much would it cost to buy a tanker truck vehicle like (point towards the vehicle in front)?

116. Are you a member of any professional association? If YES, do you pay a fee every year?

If YES, how much have you paid this year?

117. Approximately how many tanker trucks get water from this source (cumulative)?

In the peak season
Off-peak season tanker trucks do in a day (cumulative)?

In the peak season

Off-peak season

years

$\square$ Yes $\square$ No

Ability of the $\mathrm{HH}$

to pay

口 Other (explain)

Yes

Price/Tanke

I Y

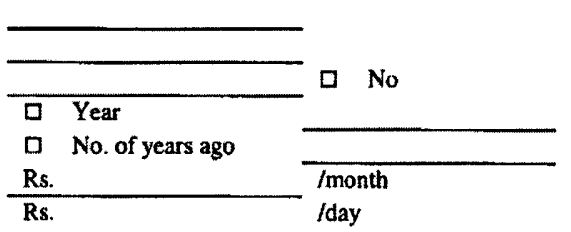

Rs. $/$ /day

Rs.

$\square$ Yes $\square$ No

Y Yes $\square$ No

Rs.

Tankers trips
Tankers trips
$\longrightarrow$ Tankers trips
Tankers trips

\section{Section 4 - Hydrant Owner}

119. How long have you been operating this hydrant?

Since




X I I I

120. How deep is the boring of the well?

121. How many water points do you have?

122. What is the $\mathrm{pH}$ level of the water from the wells?

123. Do you sell water to other tankers from this source?

124. If YES, how many tanker trucks buy water each day from this source?

125. Approximately how much water is sold each day from this source?

126. How much do you charge for one tanker truck filling at the water point?

127. Do you own your own tanker trucks

128. If YES, how many tanker trucks do you own?

129. How many trips in a day do these tanker trucks do?

130. Approximately, how much do you pay a tanker truck driver per month

131. How much does it cost to make a bore hole this deep?

132. How many hours does the water business operate?

133. How many people do you employ to run this operation?

134. What is the approximate expenditure on the tanker truck everyday (including petrol, maintenance etc.)

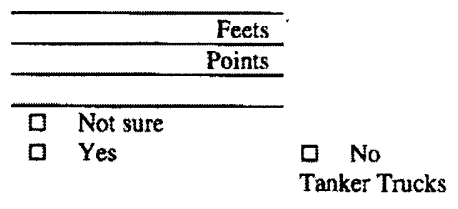

Gallons

Rs.

\begin{tabular}{|c|c|}
\hline$\square$ Yes & $\begin{array}{l}\text { ㅁ No } \\
\text { Tanker trucks }\end{array}$ \\
\hline & $\begin{array}{l}\text { Trips per day } \\
\text { /month }\end{array}$ \\
\hline
\end{tabular}

Rs

8-10hours $\square 1$-15hours
people

16-18hours

D $\quad$ 19-24 hours

Rs.

I personally interviewed all the hydrant owner that I spoke to so the information that I gathered is much more than these questions - about total cost and expenditures etc.

Enumerator Info - Please respond to these questions when you finish the interview - Thank you.

Was the person who answered the questions irritated or neryous during the interview?

How would you rate the overall quality of the interview?

ㅁ Yes

№

D Good

D Average

口 $\mathrm{Bad}$

How many people were listening while you conducted this interview with the respondent? 


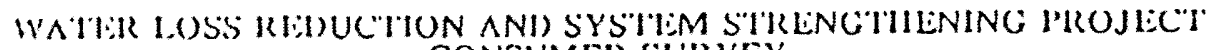
CONSUMER SUBYEY

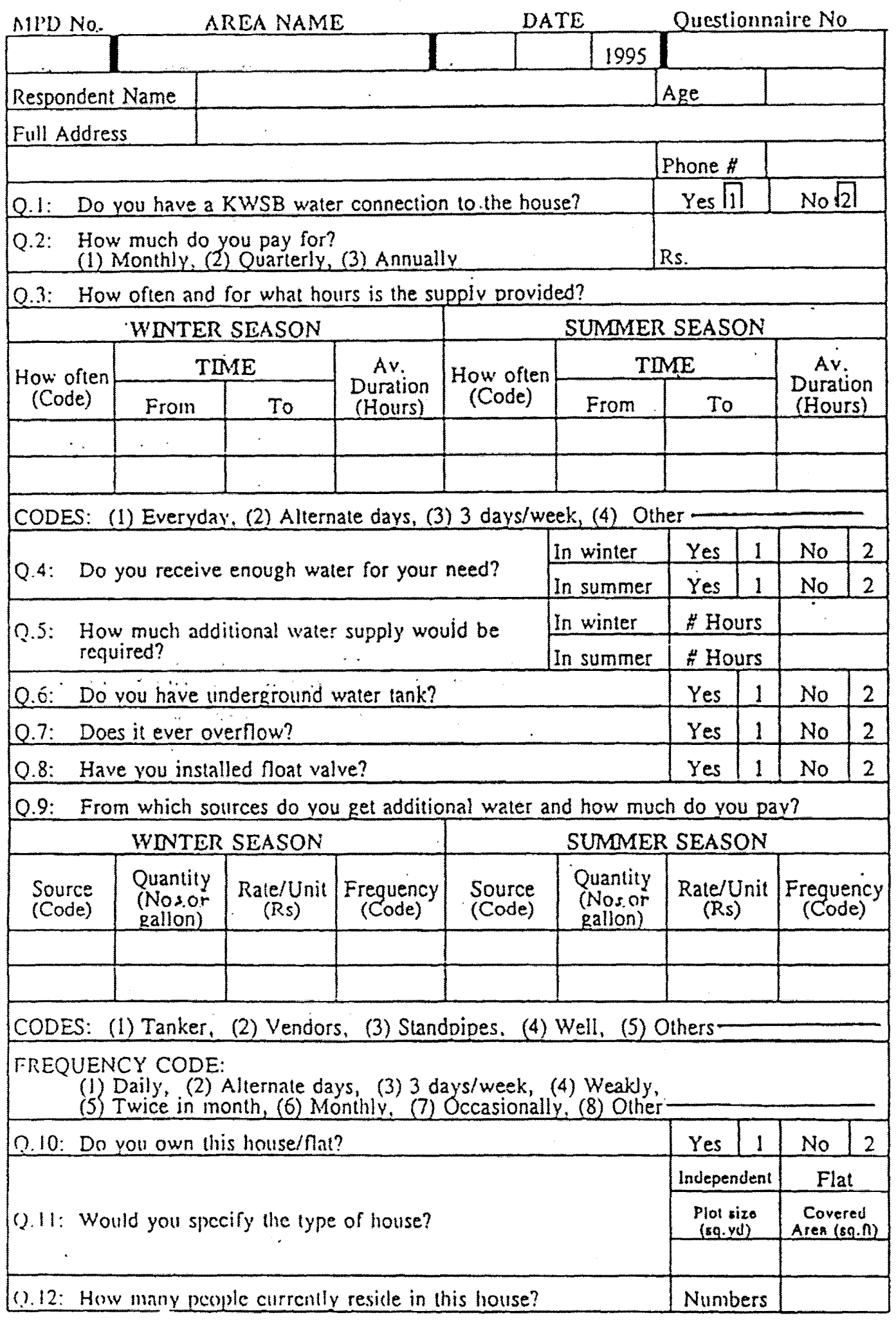




$\begin{array}{llllllllll}\mathrm{P} & \mathrm{P} & \mathrm{E} & \mathrm{N} & \mathrm{D} & \mathrm{I} & \mathrm{X} & \mathrm{I} & \mathrm{V}\end{array}$

\section{i. $\quad$ Ground water abstracted from Malir basin at Dumlottee}

The Dumlottee system was developed some 100 years ago and consists of large diameter shallow wells constructed on alluvium Malir riverbed, some $30-\mathrm{km}$ north east of the city. Present production of water from this source is 4MGD although, formerly these wells have provided up to $8 \mathrm{MGD}$. However, the yield in these wells is sensitive to rainfall and increased abstraction for irrigation and private use.

\section{ii. $\quad$ Indus Source}

\section{Haleji - Gharo System}

Haleji-Gharo system was laid in 1941 for providing 20MGD. The system consists of an inundation canal from Indus terminating into an artificial lake known as Haleji Lake. It connects from here to Gharo through an underground conduit to a pumping station from where it is directed to city 40 miles away.

\section{Greater Karachi Bulk Supply Scheme}

The Greater Karachi Bulk Water Supply Scheme (GKBWS) draws water from the Indus through Kinjhar Lake, has been developed in 4 phases of 70 MGD each, however the last phase was left incomplete with only 28MGD. The project has been taken up recently by KWSB to be completed as the Indus Balance Conveyance Scheme.

\section{iii. Hub Source}

In 1982 the Hub Water Supply Scheme was commissioned for supply of 89MGD water and later enhanced by 11MGD. This water supply is obtained from HUB impounding reservoir located some $35 \mathrm{~km}$ to the north west of Karachi. However, this 100MGD supply of water is dependent on the rainfall in the catchment area of Hub Dam, and for past three years a dry monsoon has prevailed, due to which the present supply is limited to only 30MGD.

Table 3-3: $\quad$ Existing Raw Water Source and Yields

\begin{tabular}{|r|c|}
\hline \multicolumn{1}{|l|}{ SOURCE } & YIELD (MGD) \\
\hline Dumlottee Wells & 4 \\
\hline Indus Source & \\
\hline & 20 \\
\hline GKBleji-Gharo & 259 \\
\hline Indus Balance Conveyance Scheme & $42^{*}$ \\
\hline Indus K-2 Scheme (1998) & 100 \\
\hline Hub Source & 100 \\
\hline TOTAL & 525 \\
\hline
\end{tabular}

* To be commissioned in 1998

Source: Private Sector Participation in KWSB - Draft Feasibility Report (1997) 


$\mathrm{X}$

I V

The existing raw water transfer infrastructure is generally in good condition although some of the older canals have some structural problems. The current total raw yield is around 483 MGD. ${ }^{1}$ There are six water treatment plants in Karachi, which produce around 367 MGD. Treated water is distributed around most of Karachi via 200$\mathrm{km}$ trunk mains and $3000 \mathrm{~km}$ of distribution mains.

\footnotetext{
${ }^{1}$ Does not include the water from Indus Balance Conveyance Scheme since it is not completed to date
} 


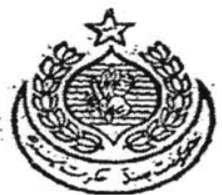

\section{dhe Sindh (Bomernment Gageffe \\ Published by Authority}

\begin{tabular}{c} 
KARACHI SATURDAY, JUNE $27,1998^{\circ}$ \\
\hline KARACHI WATER \& SEWERAGE BOARD \\
NOTIFICATION
\end{tabular}

No. MD/PS/3/3/98 in pursuance of the provisions contained in sub-section (4) of Section 8 of the Karachi Water \& Sewerage Board Act, 1996, I Brig. Mansoor Ahmec, Managing Director Karachi Water And Sewerage Board hereby give effect on and from April 1, 1998 and notify water rate schedule together with consequential conservancy (sewerage) rates schedule being linked to water rates approved by the Government as the revised schedule for water supply in respect of various billing categories. The revenue so derived in respect of water shall go to Karachi Water and Sewerage Board and in respect of Sewerage shall be shared bet een Karachi Metropolitan Corporation and Karachi Water and Sewerage Board in ratio of SO:SD.

Water Rate Schedule

\begin{tabular}{|c|c|c|c|c|c|c|c|}
\hline \multicolumn{4}{|c|}{ CATEGORY } & \multicolumn{4}{|c|}{ CATEGORY } \\
\hline 1. Residential & Plot Area & \multicolumn{2}{|c|}{ Applicable Rate } & 2. Flats & Floor Area & \multicolumn{2}{|c|}{ Applicable Rate } \\
\hline \multirow{17}{*}{$\begin{array}{l}\text { 1a. Ground Floor } \\
\text { (Connected } \\
\text { with waterline) }\end{array}$} & (Sq. Yds) & (PKR.) & (US\$) & \multirow[t]{14}{*}{\begin{tabular}{|l|}
$2 \mathrm{a}$ (Connected \\
. with waterline)
\end{tabular}} & (Sq. Ft.) & (PKR.) & (US\$) \\
\hline & $0-60$ & 26.00 & 0.50 & & $0-500$ & 34.00 & 0.65 \\
\hline & $61-120$ & 34.00 & 0.65 & & $501-800$ & 51.00 & 0.97 \\
\hline & $121-200$ & 51.00 & 0.97 & & $801-1000$ & 60.00 & 1.15 \\
\hline & $201-300$ & 77.00 & 1.47 & & $1001-1200$ & 85.00 & 1.62 \\
\hline & $301-400$ & 111.00 & 2.12 & & $1201-1500$ & 127.00 & 2.42 \\
\hline & $401-600$ & 161.00 & 3.07 & & $1501-1800$ & 220.00 & 4.20 \\
\hline & $601-1000$ & 229.00 & 4.37 & & $1801-2000$ & 280.00 & 5.34 \\
\hline & $1001-1500$ & 482.00 & 9.20 & & $2001-2500$ & 355.00 & 6.77 \\
\hline & $1501-2000$ & 618.00 & 11.79 & & $2501-3000$ & 432.00 & 8.24 \\
\hline & $2001-2500$ & 787.00 & 15.02 & & $3001-3500$ & 516.00 & 9.85 \\
\hline & $2501-3000$ & 997.00 & 19.03 & & $3501-4000$ & 608.00 & 11.60 \\
\hline & $3001-3500$ & $1,217.00$ & 23.23 & & $4001-5000$ & 888.00 & 16.95 \\
\hline & $3501-4000$ & $1,446.00$ & 27.60 & & Above 5000 & $1,141.00$ & 21.77 \\
\hline & $4001-4500$ & $1,690.00$ & 32.25 & \multirow{2}{*}{\multicolumn{2}{|c|}{$\begin{array}{l}\text { 2b Any flat not connected with } \\
\text {. waterline }\end{array}$}} & 21.00 & 0.40 \\
\hline & $4501-5000$ & $1,994.00$ & 38.05 & & & & \\
\hline & Above 5000 & $2,307.00$ & 44.03 & \multicolumn{2}{|c|}{ 3. Commercial \& Industrial } & & \\
\hline \multicolumn{2}{|c|}{$\begin{array}{l}\text { 1b. Each additional floor more } \\
\text { than } 25 \% \text { of covered area of } \\
\text { ground floor }\end{array}$} & \multicolumn{2}{|c|}{$\begin{array}{l}50 \% \text { of ground } \\
\text { floor rate }\end{array}$} & \multicolumn{2}{|c|}{$\begin{array}{l}\text { 3a Not connected with } \\
\text {. waterline }\end{array}$} & \multicolumn{2}{|c|}{$\begin{array}{l}49 \% \text { of Net Annual } \\
\text { Rental Value (NARV) }\end{array}$} \\
\hline \multicolumn{2}{|c|}{$\begin{array}{l}\text { 1c. Any property not connected } \\
\text { with waterline }\end{array}$} & 21.00 & 0.40 & \multicolumn{2}{|c|}{$\begin{array}{l}\text { 3b Connected with } \\
\text {. waterline (Unmetered) }\end{array}$} & \multicolumn{2}{|c|}{$\begin{array}{c}69 \% \text { of Net Annual } \\
\text { Rental Value (NARV) }\end{array}$} \\
\hline \multicolumn{2}{|l|}{ 5. Bulk Supply } & & & \multirow{2}{*}{\multicolumn{2}{|c|}{ 4. Government Buildings }} & \multirow{2}{*}{\multicolumn{2}{|c|}{$\begin{array}{l}\text { Same rate as } \\
\text { categories } 1 \text { and } 2 \\
\text { (residential) }\end{array}$}} \\
\hline \multicolumn{2}{|c|}{ 5a. Metered Domestic } & \multicolumn{2}{|c|}{$\begin{array}{l}\text { PKR. } 44.00 \text { (US } \$ 0.84) \\
\text { per } 1,000 \text { gallons }\end{array}$} & & & & \\
\hline \multicolumn{2}{|c|}{$\begin{array}{l}\text { 5b. Metered Industrial / } \\
\text { Commercial, etc. }\end{array}$} & \multicolumn{2}{|c|}{$\begin{array}{c}\text { PKR. } 73.00 \text { (US } \$ 1.40) \\
\text { per } 1,000 \text { gallons }\end{array}$} & & & & \\
\hline
\end{tabular}

\section{Notes:}

1. Domestic connections are not metered and rates are based on value of property; some meters have been installed for bulk supply to industrial/commercial users but most of them are no longer working

2. Sewerage charge is $50 \%$ of water charge for properties connected to sewers

3. All calculations are based on the exchange rate US $\$ 1=$ PKR. 52.4 (January, 1999)

Source: The Sindh Government Gazette, June 1998. 
List of Water Hydrants in District Central

\begin{tabular}{lll}
\hline Name & Address \\
\hline 1. & $\begin{array}{l}\text { Muhammad Bhai } \\
\text { s/o Haji Peer Pux }\end{array}$ & Bhangora Goth, F.B.Area, Karachi \\
2. Wazir Alam Rizvi & Jehangirabad, Nazimabad, Karachi \\
3. Abdullah Haji & Ali Muhammad Goth, Sec 11-E, North Karachi \\
4. Haji Arshad & Plot No. 363-364, Malik Anwar Goth Godhra Camp, North Karachi \\
5. Noor Ahmed Khan & Plot No. 14, Sugarcan Market, Shafiq Morr, Karachi \\
6. Shahid & Ayub Goth, Saba Cinema, New Karachi \\
7. Dha Khan & Plot No.44, Sec 11-E, Ali Muhammad Goth, North Karachi \\
&
\end{tabular}

List of Water Hydrants in District Malir

\begin{tabular}{|c|c|c|}
\hline & Name & Address \\
\hline 8. & $\begin{array}{l}\text { Gul Hassan } \\
\text { s/o Haji Abdul Ghaffar }\end{array}$ & Near Malook Hotel, under Malir Bridge, Karachi \\
\hline 9. & $\begin{array}{l}\text { Azeem } \\
\text { s/o Allah Dad }\end{array}$ & Near Malook Hotel, under Malir Bridge, Karachi \\
\hline 10. & $\begin{array}{l}\text { Haji Faiz Muhammad } \\
\text { s/o Haji Taj Muhammad }\end{array}$ & Near Malook Hotel, under Malir Bridge, Karachi \\
\hline 11. & $\begin{array}{l}\text { Karim Buksh } \\
\text { s/o Abdul Rehman }\end{array}$ & Near Malook Hotel, under Malir Bridge, Karachi \\
\hline 12. & $\begin{array}{l}\text { Ghulam Ali } \\
\text { s/o Bashir Ahmed }\end{array}$ & Plot No. 102/5, Road No.2, Cattle Colony, Landhi, Karachi \\
\hline 13. & $\begin{array}{l}\text { Mustafa Alvi } \\
\text { s/o Haji Asghar }\end{array}$ & Plot No. 74, Road No.2, Cattle Colony, Landhi, Karachi \\
\hline 14. & $\begin{array}{l}\text { Riaz Alvi } \\
\text { s/o Fazal Hussain Alvi }\end{array}$ & Plot No. 71, Road No. 2, Cattle Colony, Landhi, Karachi \\
\hline 15. & $\begin{array}{l}\text { H.M.Iqbal } \\
\text { s/o Haji Muzaffar Khan }\end{array}$ & Plot No. 132, Road No. 8, Cattle Colony, Landhi, Karachi \\
\hline 16. & $\begin{array}{l}\text { Haji Gul Muhammad } \\
\text { s/o H.Rahat } \\
\text { Muhammad }\end{array}$ & Pot No. 38-B, Road No.8, Cattle Colony, Landhi, Karachi \\
\hline 17. & $\begin{array}{l}\text { Hafiz Israr Ahmed } \\
\text { s/o Haji Muzaffar Khan }\end{array}$ & Plot No. 280/2, Road No. 8, Cattle Colony, Landhi, Karachi \\
\hline 18. & Aurangzeb H. Khan & Gul Zaib Ice Factory, Plot No. M/217, Chatai Ground, Karachi \\
\hline 19. & $\begin{array}{l}\text { Haji Khan Gul } \\
\text { s/o Hawas Gul }\end{array}$ & Opp. Gul Zaib Ice Factory, Plot No.M/217 Chatai Ground, Karachi \\
\hline \multicolumn{3}{|c|}{ List of Water Hydrants in District South } \\
\hline & Name & Address \\
\hline 20. & $\begin{array}{l}\text { Munawar Khan } \\
\text { s/o Awal Shah }\end{array}$ & $\begin{array}{l}\text { Pakola Gali No.4, Bandookwala Pakola Gali No.4, Khemsingh Road, } \\
\text { Garden, Karachi }\end{array}$ \\
\hline 21. & $\begin{array}{l}\text { Mr. Shariuddin } \\
\text { s/o Rafiquddin }\end{array}$ & Plot No. LR. 10/37, Hiranand Khemsingh Road, Garden,Karachi \\
\hline 22. & $\begin{array}{l}\text { Mr. Faisal } \\
\text { s/o Anisuddin }\end{array}$ & Plot No. LR.10/38-39, Murad Khan Rd, Garden, Karachi \\
\hline
\end{tabular}

List of Water Hydrants in District East

\begin{tabular}{lll}
\hline & Name & Address \\
\hline 23. & Qmaruddin & Plot No. 1548, Sec 32-A, Zia Colony, Korangi, Karachi \\
24. & Raees Baig & Plot No. 665, Sec 32-A, Zia Colony, Korangi, Karachi \\
25. & Suleman & Plot No. 102, Sec 33-G, Korangi, Karachi \\
& s/o Muhammad Ali & \\
26. & Hameed & Plot No. 103, Sec 33-G, Korangi, Karachi \\
27. & Akber Ali & Plot No. 8-9, Sec 33-D, Korangi No. 2 1/2, Karachi
\end{tabular}


28. Malik Usman Ghani s/o Abdul Hameed

29. Rafiq s/o Maqsood

30. Farhan

31. Muhammad Saleem

32. Abdul Aziz s/o Chotey Mian

33. Soofi Zakauddin

34. Rasheed s/o Rahim

35. Syed Muzzamal Hussain

36. Muhammad Nazir s/o M. Aslam

37. Naeem s/o Saleh

38. Muhammad Iqbal

39. Nazar Ali s/o M. Ebrahim

40. Rasheed

41. Haji Ikram

42. M. Hussain Bhatti s/o Gulab Din

43. Nasir

44. Shahid Khan s/o Sher Muhammad

45. Sultan Ahmed s/o Muhammad Ayub

46. Haji Riazuddin s/o Mehrajuddin

47. Ghulam Mustafa s/o Masti Khan

48. Adil Iqbal s/o Mehrajuddin

49. Mian Hamid Muzaffar

50. Akhtar Baloch s/o Khuda Buksh

51. Akhtar Baloch s/o Khuda Buksh

52. Rizwan s/o M. Sabir

53. Malik Feroz s/o Khuda Buksh

54. Ali Hassan

55. Muhammad Farooq s/o Ali Akhtar

56. Mazhar Ghani s/o Abdul Ghani

57. Muhammad Younis

58. Abdul Rehman Haswani s/o Altaf Majeed

59. Abdul Rehman Haswani s/o Altaf Majeed

60. M.S. Tariq s/o M.M. IIyas
Plot No. 112, Sec 33-D, Korangi No. 2 1/2, Karachi

Plot No. 4, Sec 33-G, Korangi No. 2 1/2, Karachi

Plot No. 3, Sec 33-G, Korangi No. 2 1/2, Karachi

Plot No. 124, Sec 33-D, Korangi No. 2 1/2, Karachi

Plot No. 164, Sec 32-D, Korangi No. 2 1/2, Karachi

Plot No. 64, Sec 32-D, Korangi, Karachi

Plot No. 3, Sec 32-D, Korangi, Karachi

Plot No. 635, Zia Colony, Sec 32-A, Korangi, Karachi

Plot No. B/679, Sec 32-A, Korangi, Karachi

Plot No. I-88, Sec 32-E, Korangi , Karachi

Plot No. 179, Sector 32-D, Korangi, Karachi

Plot No. 5, Sec 32-D, Nasir Colony, Korangi, Karachi

Plot No. D-9, Sec 31-D, Nasir Colony, Korangi, Karachi

Plot No. 12, Sec 41-B, Korangi, Karachi

Plot No. 3, Ziaul Haq Colony, Gulshane Iqbal, Karachi

Plot No. 3, Ziaul Haq Colony, Gulshane Iqbal, Karachi

Plot No. 72, Rajput Colony, Gulshane Iqbal, Karachi

Plot No. 3994, Scout Colony, Merroville-III, Karachi

Plot No. 423, Natha Street, Nishtar Road, Karachi

Plot No. 70/2, Talpur Street, Garden East, Karachi

Opp. Novelty Cineme, Plot No. 621/1, Nishtar Road, Karachi

Plot No. GRW-440/1, Nishtar Road, Karachi

Plot No. 427, Natha Street, Garden East, Karachi

Plot No. 428, Natha Street, Garden East, Karachi

Plot No. 429, Natha Street, Garden East, Karachi

Plot No. 416-417, Mangi Gali, Lasbella, Karachi

Plot No. 97, Darakshan Society, Malir, Karachi

Azeem Goth, Near Govt. School, Block 4-A, Karachi

Plot No. 5, Ziaul Haq Colony, Block 1, Karachi

Plot No. R-207,13-D-2,PRECHS, Gulshane Iqbal, Karachi

Plot No. 440/1/2, Nishtar Road, Karachi

Plot No. A-440/1/2, Nishtar Road, Karachi

Plot No. 65, Nishtar Road, Karachi 


\begin{tabular}{cccccccccc} 
A & P & P & E & N & D & I & X & V & I \\
\hline N A M E & $\&$ & A D D R E S S E S & O F & P R I V A T E & H Y D R A N T S
\end{tabular}
61. Muhammad Hussain s/o Syed Inayat M. Shah
62. Zakauddin s/o Mian Alam Din
Plot No. B-664, Sec 32-A, Korangi No.1, Karachi
Plot No. 32-D, Nasir Colony, Korangi, Karachi

List of Water Hydrants in District West

\begin{tabular}{|c|c|c|}
\hline & Name & Address \\
\hline 63. & $\begin{array}{l}\text { Muhammad Ayub } \\
\text { s/o Hamza Brohi }\end{array}$ & Plot No. 135-D, Haroonabad, Shershah, Karachi \\
\hline 64. & $\begin{array}{l}\text { S.Ishrat Ali } \\
\text { s/o Basharat Ali }\end{array}$ & D-247, Haroonabad, Shershah, Karachi \\
\hline 65. & $\begin{array}{l}\text { Maqbool Hussain } \\
\text { s/o Ghulam Hussain }\end{array}$ & Plot No. 314, Brohi Mohala, Shershah Village, Karachi \\
\hline 66. & $\begin{array}{l}\text { Mir Nasir } \\
\text { s/o Asghar Ali } \\
\text { M/S. Mir Nasir Water } \\
\text { Supply }\end{array}$ & D-243, Haroonabad, Shershah, Karachi \\
\hline 67. & $\begin{array}{l}\text { Javid Baloch } \\
\text { s/o A.Hameed Baloch }\end{array}$ & Plot No. 63, Brohi Mohala, Shershah, Karachi \\
\hline 68. & $\begin{array}{l}\text { Talib Hussain } \\
\text { s/o Mumtaz }\end{array}$ & $\begin{array}{l}\text { Plot No. 234, SITE Aftab Godown, Haroonabad } \\
\text { Shershah, Karachi }\end{array}$ \\
\hline 69. & $\begin{array}{l}\text { Malik Muhammad } \\
\text { s/o Sher Muhammad }\end{array}$ & Plot No. D-69/A, Sawab Village, Shershah, Karachi \\
\hline 70. & Younus (KW\&SB) & Hub River Road, Muhajir Camp No.3, Lassi Para, Karachi \\
\hline 71. & $\begin{array}{l}\text { (a) Aziz Kiyani } \\
\text { (b) Bashir Kiyani }\end{array}$ & Opp. Police HQ, Sector 4, Nai Abadi, Baldia, Karachi \\
\hline 72. & $\begin{array}{l}\text { Haji Muhammad Amin } \\
\text { s/o Naik Muhammad }\end{array}$ & Qrt. No.360, Sec 4-C, Baldia Nai Abadi, Karachi \\
\hline 73. & - do- & Qrt. No.248, Sec 4-C, Tauheed Nagar, Karachi \\
\hline 74. & Aurangzeb & Qrt. No. 359, Sec 4-C, Nai Abadi, Baldia, Karachi \\
\hline 75. & $\begin{array}{l}\text { Samandar Khan } \\
\text { s/o Muhammad Akram }\end{array}$ & Plot No. 472,473,474, Sec 8, Baldia Nai Abadi, Karachi \\
\hline 76. & $\begin{array}{l}\text { Muhammad Yusuf } \\
\text { s/o Muhammad Zafar }\end{array}$ & Plot No.484, Sec 4-D, Baldia Nai Abadi, Karachi \\
\hline 77. & $\begin{array}{l}\text { Yousuf } \\
\text { s/o Jabbar }\end{array}$ & Plot No. 486, Sec 4-D, Baldia Nai Abadi, Karachi \\
\hline 78. & $\begin{array}{l}\text { Muhammad Bashir } \\
\text { s/o Mehmood }\end{array}$ & Plot No. 488, Sec 4-D, Baldia Nai Abadi, Karachi \\
\hline 79. & Chanzeb & Plot No. 799, Sec 4-D, Baldia Nai Abadi, Karachi \\
\hline 80. & $\begin{array}{l}\text { Abdul Ghaffar } \\
\text { s/o Abbas Ali }\end{array}$ & Plot No. 30/C, Sec 8, Baldia Nai Abadi, Karachi \\
\hline 81. & $\begin{array}{l}\text { Rashid } \\
\text { s/o A.Rahim }\end{array}$ & Plot No. 52/C, Sec 8, Baldia Nai Abadi, Karachi \\
\hline 82. & $\begin{array}{l}\text { Guhlam Hussain Shah } \\
\text { s/o Muzzafar Shah }\end{array}$ & Plot No. 492, 493, Baldia Nai Abadi, Karachi \\
\hline 83. & $\begin{array}{l}\text { Syed Wali } \\
\text { s/o Samad Khan }\end{array}$ & Plot No. 791, Sec 4-D, Baldia Nai Abadi, Karachi \\
\hline 84. & $\begin{array}{l}\text { Muhammad Irshad } \\
\text { s/o Said Alam }\end{array}$ & Plot No. 169, Sec 4, Baldia Nai Abadi, Karachi \\
\hline 85. & $\begin{array}{l}\text { Habibur Rehman } \\
\text { s/o Amir Ahmed }\end{array}$ & Plot No. 225-I, Sec 4, Baldia Nai Abadi, Karachi \\
\hline 86. & $\begin{array}{l}\text { Hafiz Abdul Rahman } \\
\text { s/o Muhammad Hanif }\end{array}$ & Plot No. 270, Sec 4-I, Baldia Nai Abadi, Karachi \\
\hline 87. & $\begin{array}{l}\text { Tariq Ali } \\
\text { s/o Murid Hussan }\end{array}$ & United Colony, New Mewa Shah Graveyard, Karachi \\
\hline
\end{tabular}




$\begin{array}{lccccccccc}\text { A } & \mathrm{P} & \mathrm{P} & \mathrm{E} & \mathrm{N} & \mathrm{D} & \mathrm{I} & \mathrm{X} & \mathrm{V} & \mathrm{I}\end{array}$

\begin{tabular}{|c|c|}
\hline 3. & $\begin{array}{l}\text { Ahmed Gul } \\
\text { s/o Habib Gul }\end{array}$ \\
\hline 89. & $\begin{array}{l}\text { Abdul Rashid } \\
\text { s/o M.Qayyum }\end{array}$ \\
\hline 90. & $\begin{array}{l}\text { Farha Zaib } \\
\text { w/o Ishrat Hussain }\end{array}$ \\
\hline 91. & $\begin{array}{l}\text { Ghulam Muhammad } \\
\text { s/o Mulla A.Hakim }\end{array}$ \\
\hline 92. & $\begin{array}{l}\text { Noor Muhammad } \\
\text { s/o A.Rehman }\end{array}$ \\
\hline 93. & $\begin{array}{l}\text { Haji Riazuddin } \\
\text { s/o Mirajuddin }\end{array}$ \\
\hline 94. & $\begin{array}{l}\text { Amna Khatoon } \\
\text { s/o H.A.Majeed }\end{array}$ \\
\hline 95. & $\begin{array}{l}\text { Syed Israr Ali } \\
\text { s/o Haji Kabir }\end{array}$ \\
\hline 96. & $\begin{array}{l}\text { Haji Taj Muhammad } \\
\text { s/o Haji Fazalur Rahman }\end{array}$ \\
\hline 97. & Ejaz \\
\hline 98. & $\begin{array}{l}\text { Muhammad Yousuf } \\
\text { s/o Muhammad Buksh }\end{array}$ \\
\hline 99. & Master Qayum \\
\hline 100. & $\begin{array}{l}\text { Yasin } \\
\text { s/o Haji Sadiq Shakeel } \\
\text { Mabil }\end{array}$ \\
\hline 10 & $\begin{array}{l}\text { Jeans Khan } \\
\text { s/o Qadir Khan }\end{array}$ \\
\hline 102 & $\begin{array}{l}\text { Mian Abid Manzoor } \\
\text { s/o Mian Manzoor Hussain }\end{array}$ \\
\hline 103 & $\begin{array}{l}\text { Khawaja Kabeer Ahmed } \\
\text { Muneer }\end{array}$ \\
\hline
\end{tabular}

105. Shahnawaz

106. Qadir Buksh s/o Salah Muhammad -do-
-do-

Plot No. 5, United Colony. New Mewa Shah Graveyard

Karachi

Opp. United Colony, Mewa Shah Graveyard, Karachi

C-9, South Avenue, Karachi

D-9, SITE, Karachi

Plot No. D-19, SITE, Karachi

Plot No. D-40 A, SITE, Karachi

Ahmed Textile Printing Enqq. Works, C-54, SITE, Karachi

Mehran Steel Company, C-8, South Ave., SITE, Karachi

C-29, South Avenue. SITE, Karachi

Baig Enterprise, D-270, SITE, Karachi

Plot No. 166, Bismillah Hotel, Asif Colony, Karachi

Behind Millat Fan Company, SITE, Karachi

Plot No. C-11, SITE, Karachi

Plot C-11/B, SITE, Karachi

Asif Colony, Near Manghopir Maternity Home, Manghopir Karachi

Asif Colony, Near Manghopir Maternity Home, Manghopir Karachi

Brohi Mohala, Shershah Village, Karachi

List of Registered Water Hydrants

\begin{tabular}{|c|c|c|}
\hline & Name & Address \\
\hline 1. & $\begin{array}{l}\text { Mr. Abdul Rehman Aswani } \\
\text { s/o Mr. Abdul Rehman Aswani }\end{array}$ & M/S. S.T. Hydrant, Plot No.440/1/2, Nisther Road, Garden \\
\hline 2. & $\begin{array}{l}\text { Mr. Shariuddin } \\
\text { s/o Rafiuddin }\end{array}$ & $\begin{array}{l}\text { M/S. Shakil Hydrant Plot No. 37, Fikhri Line, Hiranand } \\
\text { Khemsigh Rd. Garden }\end{array}$ \\
\hline 3. & $\begin{array}{l}\text { Mr. Faisal Anisuddin } \\
\text { s/o Anisuddin Mumtaz }\end{array}$ & M/S. Faisal Hydrant, Plot No. LR. 10/38, 39, Murad Khan Road. \\
\hline 4. & $\begin{array}{l}\text { Mr. Munawar Khan } \\
\text { s/o Awal Shah Khan }\end{array}$ & $\begin{array}{l}\text { M/S. Khan Afridi Hydrant Plot No.Gali No.4,Pakola } \\
\text { Gali,H.Khemsigh Rd }\end{array}$ \\
\hline 5. & $\begin{array}{l}\text { Mr. Ghulam Mustafa Zari Khan } \\
\text { s/o Masti Khan }\end{array}$ & $\begin{array}{l}\text { M/S. Gallent Corporation Hydrant, Plot No. } 72 / 2 \text {,Talpur Street, } \\
\text { Garden West }\end{array}$ \\
\hline 6. & Mr. Haji Riazuddin & $\begin{array}{l}\text { M/S. Mashalla Hydrant, Plot No. } 493 \text {, Kooruddin Nath St., } \\
\text { Nisther Road }\end{array}$ \\
\hline 7. & Mr. Adeel Iqbal & M/S. Adeel Hydrant, 621/1, Novelty Cinema, Nisther Rd. \\
\hline 8. & $\begin{array}{l}\text { Mian Hamid Muzaffar } \\
\text { s/o Mian Muzzaffar Humair }\end{array}$ & $\begin{array}{l}\text { M/S. Pagganwalla Hydrant, Plot No. GRW.440/1, Nisther } \\
\text { Road. }\end{array}$ \\
\hline 9. & $\begin{array}{l}\text { Mr. Ejazur Rehman } \\
\text { s/o Habibur Rehman }\end{array}$ & M/S. Mehran Steel Corporation, C-8/A, S.I.T.E, Karachi \\
\hline
\end{tabular}




\section{\begin{tabular}{cccccccccc} 
A & P & P & E & N & D & I & X & V & I \\
\hline
\end{tabular}}

10. Mr. Muhammed Qayum s/o Muhammed Khalil

11. Mr. Ghulam Muhammed s/o Mulla Abdul Hakim

12. Mr. Ahmed Gul s/o Habib Gul

13. Ghulam Mustafa Khokat s/o Naseer Hussain Khokar

14. Mrs. Farah Zaib s/o Ishrat Hussain

15. Mr. Mir Nisar s/o Asghar Ali

16. Mr. Ali Hassan s/o Khair Muhammed

17. Muhammed Haroon s/o Muhammed Ayub

18. Mr. Ghulam Ali s/o Bashir Ahmed

19. Mr. Sultan Ahmed s/o Muhammed Ayub

20. Mr. Muhammed Younas

21. Mr. Muhammed Hussain Bhutti

22. Mr. Mian Abid Manzoor

23. Mr. Haji Taj Muhammed s/o Haji Fazlur Rehman

24. Mr. Wazir Alam Rizvi

25. Mr. Krduakhan s/o Abdullah
M/S. Quyum Hydrant, Plot No. D-255/A, S.I.T.E, Karachi

Opp: United Colony, Mewa Shah Grave Yard, Karachi

Opp: United Colony, Mewa Shah Grave Yard, Karachi

Opp: United Colony, Mewa Shah Grave Yard, Karachi

Plot No. 5, Mewa Shah Grave Yard, Karachi

Plot No. D-243, Haroonabad, Shershah, Karachi

Plot No. 097, Dharakshan Society

Plot No. 398 Sector 11-A Amin, Ayub Goth Near Industrial Area

Plot No. 600, Street No. 5, Cattle Colony Landhi

Plot No. 3994, Scheme No. 33, Metrowille III, Gulshan Iqbal

M/S. Gilant Water Hydrant, R-207, Sector 13-D-2, P.R.E.C.H.S, Gulshan Iqbal

M/S. Bhutti Hydrant, Plot No. 3, Ziaul Haq Colony, Gulshan

Iqbal

Water Hydrant, Plot No. C/11, S.I.T.E, Karachi

$\mathrm{M} / \mathrm{S}$. Ahmed Textile Printing \& Engineering Works, Plot No.

S/54, S.I,T.E, Karachi

Jehangirabad Water Hydrant, B.Road Nazimabad

Plot No. 44, Sector 11/E Ali Muhammad Goth North Karachi

Notes:

1. The names bolded are those hydrants which have permission to sell water from their hydrant for drinking purposes, all the rest of the private hydrants are only permitted to sell water for non-drinking purposes.

\section{Source: Karachi Metropolitan Corportation (KMC), Director Health Service}




\begin{tabular}{cccccccccc} 
A & P & P & E & N & D & I & X & V & I \\
\hline A R E A S & I N & K A R A C H I & W H E R E & VE E N D E D & W A T E R & IS S & S U P P L IE D
\end{tabular}

Areas identified by the Tanker trucks drivers and owners in Karachi where they are delivering water in the City

1. Bada Board

2. Bahdurabad

3. Baloach Colony

4. Bath Island

5. Bilal Colony

6. Bufferzone

7. Chamra Mandi

8. Clifton

9. Defense

10. Gizri

11. Gulshan-e-Iqbal

12. Hill Park

13. Khopara Par

14. Korangi

15. Lea Market,

16. Liaqatabad

17. Mahamoodabad

18. Malit

19. Malir Town

20. Manzoor Colony

21. Metroville

22. Mill Area

23. Mohajir Colony

24. Muhajir Camp

25. Muslimabad

26. Nazimabad

27. New Karachi Industrial area

28. PECHS

29. Rasheedabad

30. Saddar

31. Shershah

32. Shirin Jinnah Colony

33. SITE

34. Society

35. Sohrab goth

36. Tariq Road

37. Thektee Colony

38. West Wharf 
CONTROL AND REGULATIONS OF HYDRANTS, BYLAWS 1994

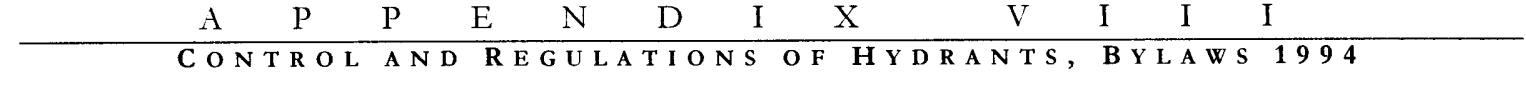

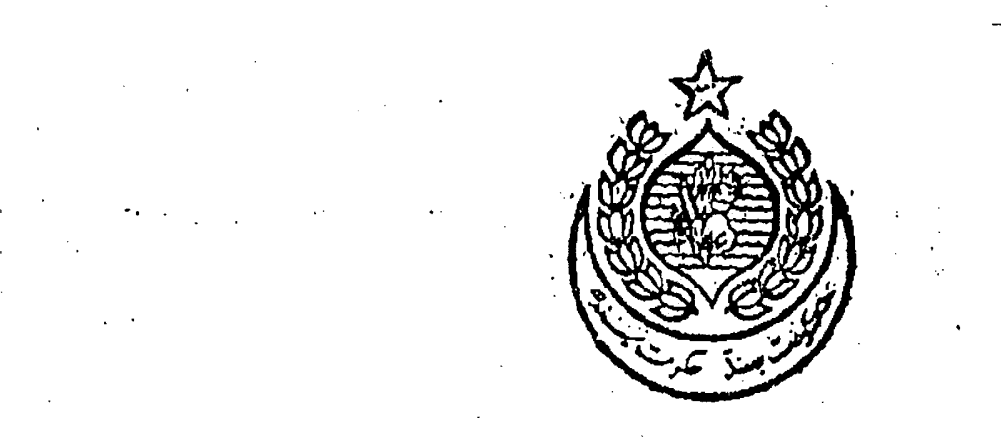

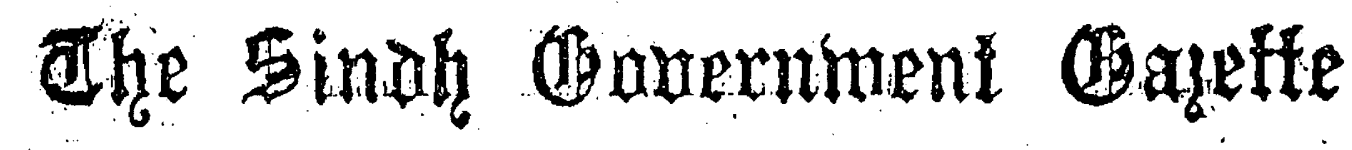 Published by Authority
}

\author{
Karachi, Thursday, February 21, 1994
}

\section{BY THE DIRECTOR HEALTH SERVICES \\ KARACHI METROPOLITAN CORPORATION (KMC)}

NOTIFICATION

Karachi, the $12^{\text {th }}$ February, 1994

$\mathrm{KMC} / \mathrm{DOC}(\mathrm{PA})-008 / 94$. In exercise of the powers conferred by section 104 (1) of the Sindh Local Government Ordinance 1979, read with item 6 under the heading "OPTIONAL FUNCTIONS" of part - II of Schedule - II and item 25 of Schedule - II. In the said ordinance, the Karachi Metropolitan Corporation (KMC) with the sanction of the Government is pleased to make the following bylaws.

1. Short title and commencement.

i) These bye-laws may be called, the Karachi Metropolitan Corporation ( Control and Regulation of Private Sources of Water supply / Hydrants) Bylaws , 1994

ii) They shall come into force at once.

2. Definitions:- In these Bye-laws unless the context otherwise requires the following expressions shall have the meanings hereby respectively assigned to them, that is to say ;

a) "Board" means the Karachi Water and Sewerage Board;

b) "Corporation" means the Karachi Metropolitan Corporation;

c) "Director" means the Director Health Services of Karachi Metropolitan Corporation;

d) "Hydrant" means any private source of water supply from where the water is supplied or distributed and includes tube-well or channel but does not include well or water pump dug or installed for domestic use;

e) "Licensee" means the person (persons) running a hydrant/private source of water supply duly sanctioned by the corporation under a license issued by the Director Health Services as per these bye-laws;

f) "License" means permit/permission/license, issued by the Director with the prior approval of the Municipal Commissioner for running, digging, providing, operation or carrying on a hydrant/source of water supply; 
g) "Owner" means the owner, proprietor, occupant, manager, supervisor, of a hydrant/source of water supply or any other person or representative/servant authorized by the owner to work as in charge of hydrant/source of water supply on behalf of the owner;

h) "Permit" means a permit issued under these bye-laws authorizing a vehicle to carry water from a hydrant;

i) "Source of water supply" means a private source of water supply such as well, water pump, hydrant, tube well or channel etc. being run/operated by its owner for distributing /supplying / selling water for any purpose to the consumer/public;

j) Vehicle:- means a tanker/cart or any driven vessel used for distribution/supply/sale of water from hydrant/source of water supply.

3. Prohibition against establishment and continuance of hydrant: - No hydrant shall be established, maintained, run, or continued except in accordance of these bye-laws.

4. Establishment of a hydrants:-

(1) Any person intending to establish a hydrant and any intending that a hydrant already existence should be confirmed as well, shall, make an application to the Director accompanied by

i) a site plan in duplicated showing location and address with construction thereon, if any, with documentary proof that the site is owned by or is on lease with applicant

ii) actual area of the site

iii) Nature of source of water supply whether it is a private source of water supply to be supported by a certificate from the Chief Engineer (water) of the Board, that the hydrant is not provided water from official source of water supply.

iv) Details of operation of the hydrant ;

v) A list of the persons working at the hydrant along with the photo copies of their NIC's

(2) The applicant shall furnish such other information or document as may be required by the Director.

(3) The Director may on receipt of the application, arrange the laboratory test of water and inspect or cause to be inspected the hydrant from public health point of view and make such inquiries as he may consider necessary.

(4) The Director may, after taking action under clause (2) either grant application, or for some reasons to be recorded in writing reject it and if the Director grants the application shall issue a license to the applicant.

(5) The license shall specifically state the purpose for which the water of the hydrant can be used. The license shall:-

(i) construct the floor of the building of the hydrant smooth with concrete or other impervious material providing therein trapped drains for safe disposal of water;

(ii) maintain the walls and ceilings of the building and drains clean and in good order;

(iii) keep hydrant at all times in good order, cleared from silt, refuse and decaying matters;

(iv) protect the water from contamination ;

(v) make proper arrangements for purification alteration, chlorination, and keep the water potable and wholesome, in accordance with the instructions of the Board of Directors;

(vi) Ensure that no operation of the hydrant is allowed to carry on after 7:00 PM and before 7:00 AM and no nuisance or health hazard is caused to the inmates and neighboring residents of the locality by such operation.; 
(vii) arrange half-yearly medical examination of the person working in the hydrant from a registered medical practitioner and ensure that they are free from infection and have no communicable disease and the certificate issued by the medical practitioner in this behalf shall be kept on record to be produced on demand; and

(viii) comply with the instructions consistent, with these Bye-laws issued by the Director

6. Continuance of existing hydrants:-

(1) A hydrant not in existence on the coming into force of these bylaws; shall be established only after a license has been issued under clause (4) of bylaws.

(2) A hydrant already in existence shall not be continued for more than sixty days from the date from which these bylaws come into force, until an application for its continuance.

(3) Where an application for the aforesaid has been made in respect of an existing hydrant and such application is rejected, the notwithstanding the period of sixty days provided in clause (2) the hydrant may be continued for a period of fifteen days from the date on which the application is rejected

(4) If any hydrant is established or continued in contravention of these bylaws such hydrants shall without prejudice to any other action be liable to be demolished at the risk and cost of the owner of such hydrant.

7. (1) The Director or any person authorized by him shall from time to time carry out inspection of the hydrant and the vehicles granted licenses or as the case may be permits and shall forward inspection reports to the Government.

(2) The license or permit and other relevant record shall always be available for inspection by the director or any other officer/official authorized by him on his behalf.

8. (1) Any well or water pump dug or installed for domestic purpose shall be governed in accordance with the Sindh Local Government Ordinance, 1979, and shall be kept and managed in accordance with the instructions issued from time to time by the Director (2) The water drawn from such well or pumps shall not be utilized for drinking purposes unless it is found fit for human consumption by laboratory tests to be arranged by the Director on the terms and conditions specified by him.

9. (1) No vehicle shall be used for carrying water from a hydrant unless a permit has been obtained in respect thereof

(2) No vehicle shall carry water from a hydrant other than the hydrant mentioned in the permit

10. The permit shall be subject to the following conditions:-

(i) The drinking water and the non-drinking water shall be carried by the separate vehicles reserved for the purpose;

(ii) The vehicle reserved for carrying drinking water shall be painted with green color with words "Drinking Water" while the vehicles reserved for carrying non drinking water shall be painted red in color with the words "Non Drinking Water";

(iii) The number of the permit shall be painted at the conspicuous place on the body of the vehicle;

(iv) The vehicle shall be used exclusively for the purpose they have been reserved;

(v) The vehicle reserved for carrying drinking water shall be maintained in such a manner that the water being carried by them is not contaminated;

(vi) The vehicle reserved for carrying drinking water shall not carry water which is not fit for drinking purpose, failing which the vehicle shall be liable to be seized; and 


$\begin{array}{llllllllllll}A & P & P & E & N & D & I & X & V & I & I & I\end{array}$

CONTROL AND REGULATIONS OF HYDRANTS, BYLAWS 1994

(vii) The water tanker fixed on the vehicle and other devices such as nozzles, hose pipes, delivery pipes, taps, cocks, etc. shall be free from any leakage and maintained hygienically.

11. (1) License or permit shall be granted on payment of the fee as prescribed in schedule to these bylaws.

(2) The license or permit shall be valid for the financial year or part thereof, renewable on yearly basis subject to the compliance of the prescribed conditions and payment of the prescribed fee.

12. The director shall maintain a separate account for all the income accrued under these bylaws and shall furnish a detailed account to the Government annually.

13. (1) The license and permit shall be liable to be suspended for the period specified by the Director, if the director on inspection or otherwise is satisfied that the license or as the case may be permit holder has committed breach of any terms or conditions of the license or permit or any provision by these bye-laws;

(2) The hydrant or vehicle where license with a license or as the case may permit whose license has been suspended shall not supply water during the period of suspension of license or permit.

\section{SCHEDULE OF LICENSE FEE \\ SCHEDULE OF LICENSE FEE FOR PRIVATE SOURCES OF \\ WATER SUPPLY (HYDRANTS)}

Fee is to be levied and charged on the mechanical power being used for carrying on the trade.

1. LICENSE FEE FOR SUPPLY OF WATER FOR DRINKING PURPOSE

\begin{tabular}{|c|c|c|}
\hline$\underline{\text { S.NO }}$ & MECHANICAL POWER & RATE OF FEE \\
\hline a. & 1 H.P TO 5 H.P & Rs. 300 PER MONTH \\
\hline b. & Above 5 H.P TO 10 H.P & Rs. 400 -do- \\
\hline c. & Above 10 H.P TO 20 H.P & Rs. 600 -do- \\
\hline d. & Above 20 H.P & Rs. 800 -do- \\
\hline
\end{tabular}

2. LICENSE FEE FOR SUPPLY OF WATER FOR OTHER PURPOSE THAN DRINKING

\begin{tabular}{|c|c|c|}
\hline$\underline{\mathrm{S} . \mathrm{NO}}$ & MECHANICAL POWER & RATE OF FEE \\
\hline a. & 1 H.P TO 5 H.P & Rs. 200 PER MONTH \\
\hline b. & Above 5 H.P TO 10 H.P & Rs. 300 -do- \\
\hline c. & Above 10 H.P TO 20 H.P & Rs. 500 -do- \\
\hline d. & Above 20 H.P & Rs. 700 -do- \\
\hline
\end{tabular}

3. VEHICLES SUPPLYING/SELLING WATER

$\begin{array}{lll}\text { a. Water sold for drinking purposes } & \text { Rs. } 200 \text { Per vehicle Per month } \\ \text { b. Water sold for purposes other than (a) above } & \text { Rs. } 100 \text { Per vehicle Per month }\end{array}$ 